\title{
amambaias e licófitas do Parque Estadual Turístico do Alto Ribeira, Iporanga, SP, Brasil
}

\section{Frederico fregolente faracco Mazziero}

Parte da dissertação de mestrado. Universidade Federal do Paraná-UFPR, Departamento de Botânica, Curitiba, Paraná, Brasil.

E-mail: fredericobio2@gmail.com

\author{
Paulo Henrique labiak \\ Universidade Federal do Paraná-UFPR, Departamento de Botânica, Curitiba, Paraná, Brasil.
}

\section{Mateus luis Barradas Paciencia}

Universidade Paulista (UNIP), São Paulo, São Paulo, Brasil.

\begin{abstract}
Resumo: O Parque Estadual Turístico do Alto Ribeira é um importante remanescente de Floresta Atlântica, pois abriga grande biodiversidade e, junto com outras Unidades de Conservação em seu entorno, constitui um dos maiores maciços desta formação no país. O Parque está localizado na porção sudeste do Estado de São Paulo e é predominantemente constituído por Floresta Atlântica, a qual é responsável por abrigar um importante número de espécies de samambaias e licófitas, onde estas plantas constituem um elemento conspícuo da flora no subosque. Embora muitos levantamentos florísticos tenham sido publicados para áreas de Floresta Atlântica do Estado de São Paulo, poucos fornecem meios para a identificação das espécies. O objetivo principal no presente estudo é apresentar uma chave para a identificação de 251 espécies de samambaias e licófitas encontradas no Parque. Além disso, foram feitas também comparações entre as espécies encontradas e taxa próximos, além de dados sobre os ambientes de ocorrência das espécies na área de estudo.
\end{abstract}

Palavras-chave: Biodiversidade, Chave de identificação, Floresta Atlântica, Floresta Ombrófila.

\section{Ferns and lycophytes from Parque Estadual Turístico do Alto Ribeira, IPORANGA, SP, BRAZIL}

\begin{abstract}
The "Parque Estadual Turístico do Alto Ribeira" is an important remnant of Atlantic Forest, because it harbor great biodiversity and form, with others Conservation Units of its surroundings, one of the largest massifs of this formation in the country. The Park is located in the southeastern portion of São Paulo State and is predominantly composed of Atlantic Forest, which is responsible for hosting a large number of species of ferns and lycophytes, conspicuous elements in the understory. Although many floristic surveys have been published for areas of Atlantic Forest in São Paulo, just a few provide means for the identification of its species. The goal in the present study is to present a key for the identification of the 251 species of ferns and lycophytes found in the Park. By comparing the species found in the park with similar species, this paper can be also useful for the identification of species from other areas nearby.
\end{abstract}

Keywords: Atlantic Forest, Biodiversity, Identification Key, Ombrophilous Forest. 


\section{INTRODUÇÃO}

No Estado de São Paulo registra-se a ocorrência de 618 espécies de samambaias e licófitas, correspondendo à aproximadamente metade das espécies ocorrentes no Brasil (Prado et al., 2015), contribuindo para que as regiões Sul e Sudeste do país figurem como centros de endemismo e diversidade para estes grupos (Moran, 2008; Tryon, 1986). Dentre as principais localidades de ocorrência das espécies no Estado de São Paulo, destacam-se aquelas inseridas na Floresta Atlântica, principalmente na porção litorânea e em algumas regiões mais interioranas, como é o caso do Vale do Ribeira e das regiões serranas de Analândia e São Carlos (Prado, 1998; Prado \& Hirai, 2011).

Estudos florísticos conduzidos com samambaias e licófitas no Estado de São Paulo foram realizados, em sua maioria, com o intuito de fornecer uma lista de espécies ou efetuar análises sobre a composição de espécies, como é o caso de Salino \& Almeida (2008), Prado \& Labiak (2009), Mazziero \& Nonato (2015) e Mazziero et al. (2015). Há, contudo, uma parcela de estudos que também apresentaram chaves de identificação e/ou tratamentos taxonômicos das espécies registradas, podendo-se ressaltar Windisch (1992a), Boldrin \& Prado (2007); Nóbrega \& Prado (2008) e Nóbrega et al. (2016). Sem exceção, tais estudos são de suma importância por auxiliar na elaboração de floras, sendo um instrumento para auxiliar na identificação das espécies e para o conhecimento da flora nas Unidades de Conservação e remanescentes de Floresta Atlântica do Estado de São Paulo.

Neste contexto, o objetivo no presente estudo foi o de fornecer chaves para a identificação das espécies de samambaias e licófitas encontradas no Parque Estadual Turístico do Alto Ribeira (PETAR), com comentários para a diferenciação de espécies próximas e dados sobre os ambientes de ocorrência.

\section{MATERIAL E MÉTOdOS}

\section{Área dE ESTUdo}

O PETAR está situado no Vale do Ribeira, porção sul-sudeste do Estado de São Paulo, nos Municípios de Iporanga e Apiaí, sob coordenadas 2431'43" S; 4841'09" W. Abrange aproximadamente 35.712 ha e, junto com as demais áreas de proteção ao redor (especialmente o P. E. CarIos Botelho, P. E. Fazenda Intervales), compreende um dos maiores remanescentes de Floresta Atlântica do Brasil (Ribeiro et al., 2009). O Parque é constituído principalmente por Floresta Ombrófila Densa Montana e Sub-Montana (Aidar et al., 2001; Ivanauskas et al., 2012). Uma peculiaridade quanto à região é a presença de florestas estabelecidas sobre formações geológicas distintas, calcário e filito, ocorrendo lado a lado, em serras adjacentes. O Clima da região é classificado como "Cfa" de acordo com a classificação de Köppen (Alvares et al., 2014), com temperatura média anual variando entre $17-19{ }^{\circ} \mathrm{C}$ (Gutjhar, 1993) e a precipitação média anual é em torno de 1.963 mm (Karmann \& Ferrari, 2002).

\section{COLETA, IDENTIFICAÇÃO E TRATAMENTO TAXONÔMICO}

Foram realizadas sete visitas ao PETAR, de setembro de 2011 a outubro de 2012. O material botânico foi coletado através de caminhadas aleatórias percorrendo-se trilhas, estradas de acesso e o interior da floresta nos núcleos $\mathrm{Ca}$ boclos, Casa de Pedra, Ouro grosso e Santana. A herborização ocorreu de acordo com o proposto por Fidalgo \& Bononi (1984) e os materiais encontram-se depositado no herbário UPCB, com duplicadas enviadas para SP, UNIP, NY, UC e RB. Realizou-se também o levantamento de dados secundários por meio do banco de dados disponível no Species Link (Splink, 2018), sendo aceito apenas os materiais determinados por especialistas.

O tratamento taxonômico seguiu PPG I (2016) - Pteridophyte Phylogeny Group. Os autores dos nomes dos taxa foram abreviados de acordo com IPNI (2017) - International Plant Name Index.

As informações sobre a localidade de coleta "BRASIL. São Paulo, Mun. Iporanga, Parque Estadual Turístico do Alto Ribeira" foram excluídas do material examinado.

\section{Resultados e Discussão}

Foram registrados 251 taxa infragenéricos, sendo 233 espécies e um híbrido de samambaias e 17 espécies de licófitas, distribuídas em 30 famílias. Este número representa aproximadamente $40,6 \%$ das espécies encontradas no Estado de São Paulo e $28 \%$ das espécies registradas para a Floresta Atlântica, segundo o número de espécies sugerido por Prado et al. (2015).

\section{Chave de identificação das famílias de samambaias e licófitas encontra- DOS NO PETAR}

1. Folhas extremamente reduzidas à pequenas estruturas escamiformes; caules verdes.

2. Caules não ocos nem articulados; estruturas escamiformes alternas; esporângios laterais formando sinângios. 
2'. Caules ocos e articulados; estruturas escamiformes verticiladas; esporângios dispostos em estróbilos na porção apical dos ramos.

$1^{\prime}$. Folhas evidentes (microfilos ou megafilos); caules, geralmente, não verdes.

3. Plantas aquáticas, flutuantes. 10. Equisetaceae.

3'. Plantas terrícolas, rupícolas (plantas sobre rochas expostas), epífitas, hemiepífitas ou escandentes.

4. Plantas com microfilos (lâminas somente com uma nervura central); esporângios solitários, na axila adaxial dos microfilos.

5. Microfilos de disposição dística (em quatro fileiras sobre o caule, duas laterais e duas dorsais); plantas

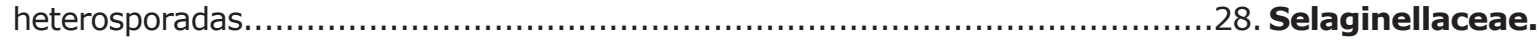
5'. Microfilos dispostos radialmente sobre o caule; plantas homospora-

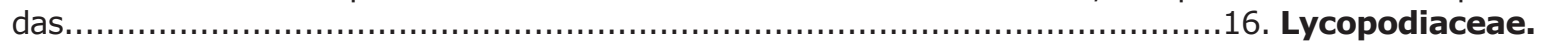

4'. Plantas com megafilos (lâminas com muitas nervuras); esporângios geralmente em grande número, abaxiais ou marginais.

6. Esporângios unidos lateralmente em sinângios.

7. Lâmina simples ou somente com o ápice furcado

20. Ophioglossaceae.

7'. Lâmina 1-3-pinada.

18. Marattiaceae.

6'. Esporângios livres.

8. Esporângios sésseis ou subsésseis, se pedunculados, nunca com mais de uma fileira de células; ânulo apical, lateral ou obliquo.

9. Esporângios com ânulo lateral rudimentar, formado por um conjunto de células pouco diferenciadas.

21. Osmundaceae.

9'. Esporângios com ânulo apical ou oblíquo, bem desenvolvido.

10. Esporângios piriformes com ânulo apical.

11. Esporângios situados em pinas basais modificadas

1. Anemiaceae.

11'. Esporângios situados em projeções na margem da lâmina

12. Frondes de crescimento indeterminado; esporângios em projeções estrobiliformes na margem da lâmina.

17. Lygodiaceae.

12'. Frondes de crescimento determinado; esporângios apenas no ápice da lâmina em esporangióforos pinatiformes.............................................................. Schizaeaceae.

10'. Esporângios globosos com ânulo oblíquo.

13. Lâmina membranácea; tecido laminar com 1-2 camadas de células; soros protegidos por invólucro cônico bilabiado ou bivalve........................................13. Hymenophyllaceae.

13'. Lâmina cartácea ou coriácea; tecido laminar com duas, ou mais, camadas de células; esporângios protegidos por indúsio ou não.

14. Plantas herbáceas; lâmina pseudo-dicotomicamente dividida; gema presente nas axilas das bifurcações......................................................................11. Gleicheniaceae.

14'. Plantas arborescentes, se herbáceas a lâmina não pseudo-dicotomicamente dividida; lâmina 2-pinado-pinatífida ou mais complexa; gemas ausentes.

15. Base do pecíolo com tricomas; soros marginais.

7. Dicksoniaceae.

$15^{\prime}$. Base do pecíolo com escamas e tricomas; soros abaxiais...................... Cyatheaceae.

8'. Esporângios pedicelados, geralmente com duas ou mais fileiras de células no pedicelo; ânulo vertical. 16. Frondes dimorfas ou hemidimorfas.

17. Pinas articuladas à raque.

15. Lomariopsidaceae.

$17^{\prime}$. Pinas não articuladas à raque.

18. Soros lineares e marginais, protegidos pela margem recurvada da lâmi-

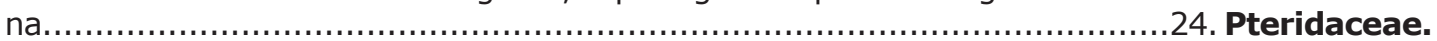

18'. Soros acrosticóides ou arredondados, se lineares, localizados ao longo da nervura central (nunca marginais).

19. Soros com indúsio.

4. Blechnaceae.

19'. Soros desprovidos de indúsio.

20. Frondes hemidimorfas.

21. Lâmina inteira; soros circulares....

22. Polypodiaceae.

21'. Lâmina 1-pinada; soros lineares, arqueados, às vezes, confluentes na maturidade....

30. Thelypteridaceae.

$20^{\prime}$. Frondes dimorfas

9. Dryopteridaceae.

$16^{\prime}$. Frondes monomorfas.

22. Fronde articuladas ao caule, com filopódio.

22. Polypodiaceae.

22'. Frondes não articuladas ao caule, filopódio ausente.

23. Soros abaxiais, situados na porção mediana entre a costa e a margem da lâmina.

24. Soros lineares.

25. Soros paralelos a costa.

26. Soros adjacentes a costa, superficiais, com indúsio; lâmina pinatissecta ou 2-pinada.

4. Blechnaceae.

Rev. Biol. Neotrop. / J. Neotrop. Biol., Goiânia, v. 15, n. 1, p. 22-72, jan.-jun. 2018 
26'. Soros medianos, em sulcos, sem indúsio, às vezes, com uma aleta marginal; lâmina inteira 24. Pteridaceae.

25'. Soros oblíquos ou perpendiculares a costa ou cóstula.

27. Soros sem indúsio, arqueados; nervuras meniscióides...

30. Thelypteridaceae.

27'. Soros com indúsio, retos; nervuras livres ou anastomosadas, mas nunca meniscióides.

28. Nervuras anastomosadas.

29. Lâmina 1-pinada.

12. Hemidictyaceae.

29'. Lâmina inteira...

2. Aspleniaceae.

28'. Nervuras livres.

30. Um soro por nervura; indúsios abrindo-se na direção do ápice da lâmina ou da pina.. 2. Aspleniaceae.

30'. Dois soros por nervura, ao menos, nos segmentos proximais; indúsios se abrindo na direção do ápice e da base da lâmina ou da pina.

3. Athyriaceae.

24'. Soros arredondados, oblongos, elípticos ou estendendo-se ao longo das nervuras secundárias.

31. Pinas/pínulas articuladas à raque/raquíola.

32. Lâmina 1-pinada

19. Nephrolepidaceae.

32'. Lâmina 2-pinada 8. Didymochlaenaceae.

31'. Pinas/pínulas não articuladas.

33. Plantas epífitas; frondes com até $20 \mathrm{~cm}$ de comprimento; lâmina inteira a pinatífida.... 22. Polypodiaceae.

33'. Plantas terrícolas, raro epífitas; frondes com mais de $30 \mathrm{~cm}$ de comprimento, lâmina 1-pinada-pinatissecta ou mais complexa.

34. Soros distribuídos ao longo de toda extensão das nervuras secundárias, muitas vezes confluentes, dando aspecto acrosticóide. 24. Pteridaceae.

34'. Soros circulares, elípticos ou oblongos, nunca distribuídos ao longo de toda extensão das nervuras secundárias, nunca confluentes.

35. Lâmina 1-pinada a 1-pinado-pinatífida.

36. Lâmina 1-pinada, com as pinas basais amplamente sulcadas no lado basioscópico e, às vezes, no acroscópico. 29. Tectariaceae.

36'. Lâmina 1-pinado-pinatissecta a 1-pinado-pinatífida, se 1-pinada, então, pinas basais inteiras.

37. Tecido laminar com pontuações translúcidas, se ausentes, então com tricomas catenados na face abaxial dos eixos.................................. Dryopteridaceae.

37'. Tecido laminar desprovido de pontuações translúcidas, tricomas furcados, estrelados, uncinados, aciculares, uni a pluricelulares, mas nunca catenados

30. Thelypteridaceae.

35'. Lâmina 2-pinada-pinatífida ou mais complexa.

38. Tricomas aciculares presentes, ao menos, nos eixos

38'. Tricomas aciculares ausentes.

30. Thelypteridaceae.

23'. Soros marginais.

39. Caule coberto por tricomas, às vezes, glabros

9. Dryopteridaceae.

39'. Caule coberto por escamas, às vezes, também

6. Dennstaedtiaceae.

40. Soros protegidos pela margem revoluta da lâmina (pseudoindú-

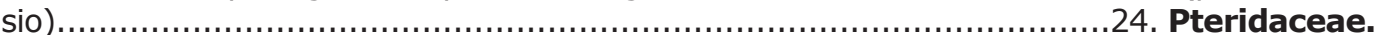

40'. Soros protegidos por indúsio verdadeiro.

41. Soros lineares, irrigados por mais de duas nervuras.

14. Lindsaeaceae.

41'. Soros obcônicos, irrigados por uma única nervura

25. Saccolomataceae.

\section{Chave para a IDENTIficação das espécies de samambaias e licófitas encon- TRADAS NO PETAR:}

\section{ANEMIACEAE}

1. Lâmina 1-pinada; ápice conforme; nervuras anastomosadas.

1.1. Anemia phyllitidis.

1'. Lâmina 1-pinado-pinatífida; ápice pinatífido; nervuras livres 1.2. Anemia raddiana.

1.1. Anemia phyllitidis (L.) Sw., Sin. Fil. 155. 1806.

Mickel (2016) reconheceu quatro variedades para esta espécie, sendo encontrada no PETAR a variedade típica. De acordo com este autor, $A$. phyllitidis var. phyllitidis difere de Anemia phyllitidis var. tweedieana (Hook.) Hassl., por apresentar pinas com ápice acuminado, o qual é arredondado a agudo na segunda. Espécie terrícola, encon-

Rev. Biol. Neotrop. / J. Neotrop. Biol., Goiânia, v. 15, n. 1, p. 22-72, jan.-jun. 2018 
trada nas trilhas ou em barrancos às margens de estradas, em locais úmidos e sombreados.

Material selecionado examinado: Mazziero \& Soller 588 (UPCB); Mazziero \& Soller 644 (UPCB).

1.2. Anemia raddiana Link, Hort. Berol. 2: 144. 1833.
Segundo Mickel (2016), Anemia flexuosa (Savigny) Sw. é a espécie mais parecida à $A$. raddiana, porém, seus esporangióforos são menores que a porção estéril da lâmina, enquanto, em $A$. raddiana, os esporangióforos são maiores. Espécie terrícola, encontrada na borda da floresta e barrancos de estradas, exposta ao sol.

Material selecionado examinado: Mazziero \& Soller 628 (UPCB); Mazziero 992 (UPCB, SP, NY, CAS).

\section{ASPLENIACEAE}

1. Caule longo-reptante (mais de $1 \mathrm{~cm}$ de distância entre as frondes) glabrescente; base do pecíolo intumescida; raque triangular em corte transversal...................................2.21. Hymenasplenium triquetrum.

$1^{\prime}$. Caule ereto, decumbente, curto-reptante ou longo-reptante, neste caso densamente escamoso; base do pecíolo não intumescida; raque arredondada em corte transversal.

2. Lâmina inteira.

3. Nervuras anastomosadas.

2.5. Asplenium brasiliense.

3'. Nervuras livres 2.20. Asplenium serratum.

2'. Lâmina 1-pinada ou mais complexa.

4. Lâmina 2-3-pinada, ao menos, na base.

5. Pecíolo e raque lustrosos.

6. Ápice da lâmina com gema prolífera

2.10. Asplenium flabellulatum.

$6^{\prime}$. Ápice da lâmina sem gema prolífera.... 2.15. Asplenium pseudonitidum.

$5^{\prime}$. Pecíolo e raque foscos.

7. Pínulas acroscópicas basais sobrepondo à raque.

2.8. Asplenium cristatum.

7'. Pínulas acroscópicas basais não sobrepondo à raque.

8. Fronde e indúsio de consistência coriácea.

2.4. Asplenium auritum.

$8^{\prime}$. Fronde e indúsio de consistência membranácea. 2.18. Asplenium scandicinum. 4'. Lâmina 1-pinada.

9. Gema prolífera presente no ápice da lâmina.

10. Ápice da lâmina não radicante.

2.12. Asplenium kunzeanum.

$10^{\prime}$. Ápice da lâmina radicante.

11. Pecíolo e raque lustrosos e não alados.

2.6. Asplenium cirrhatum.

$11^{\prime}$. Pecíolo e raque foscos e amplamente alados 2.2. Asplenium alatum.

9'. Gema ausente.

12. Pecíolo, raque e costa conspicuamente escamosos

$12^{\prime}$. Pecíolo, raque e costa glabros ou com escamas esparsas.

13. Base acroscópica das pinas laterais com uma aurícula bem desenvolvida, sobrepondo à raque..... 2.3. Asplenium auriculatum.

13'. Base acroscópica das pinas laterais desprovidas ou com uma aurícula pouco desenvolvida, que não sobrepõem à raque.

14. Lâmina com ápice conforme ou subconforme.

15. Lâmina cartácea; indúsios arqueados, aderido à nervura apenas na porção central......

ra......................................................................... Asplenium oligophyllum.

14'. Lâmina com ápice pinatífido.

16. Lâmina gradualmente reduzida na base; pecíolo menor que $1 / 5$ do tamanho da fronde.

17. Pinas pinatífidas, com ápice dos segmentos mucronados; inserção das pinas não interrompendo a ala.

2.13. Asplenium mucronatum.

$17^{\prime}$. Pinas inteiras e com a margem serreada; inserção das pinas interrompendo a ala....

2.16. Asplenium pteropus.

16'. Lâmina pouco ou nada reduzida na base; pecíolo maior que 1/4 do tamanho da fronde.

18. Lâmina com 15 pares, ou menos, de pinas laterais.

2.1. Asplenium abscissum.

18'. Lâmina com 16 pares, ou mais, de pinas laterais.

19. Nervuras acroscópicas predominantemente furcadas.

$19^{\prime}$. Nervuras acroscópicas predominantemente simples.

20. Ápice das pinas arredondado a obtuso.

2.12. Asplenium kunzeanum.

$20^{\prime}$. Ápice das pinas agudo a longo-caudado.

21. Escamas do caule nigrescentes; pinas perpendiculares em relação à raque. 2.11. Asplenium harpeodes. 
21'. Escamas do caule castanhas; pinas arqueadas e ascendentes em relação à raque. 2.17. Asplenium raddianum.

2.1. Asplenium abscissum Willd., Sp. PI. 5(1): 321. 1810.

Asplenium hostamanii Hieron., Asplenium inaequilaterale Willd. e Asplenium cruegeri Hieron. assemelham-se à $A$. abscissum, no entanto, essas três espécies apresentam a lâmina membranácea e lanceolada, enquanto, em $A$. abscissum, a lâmina é cartácea de contorno deltoide (Sylvestre, 2001). Espécie rupícola, ocorrendo nas no interior da floresta, em locais sombreados e úmidos.

Material selecionado examinado: Mazziero \& Soller 840 (UPCB, SP, UNIP, NY); Mazziero et al. 967 (UPCB, CAS, RB).

2.2. Asplenium alatum Humb. \& Bonpl. ex WiIld., Sp. PI. 5(1): 319. 1810.

De acordo com Sylvestre (2001), Asplenium rosenstockianum Brade é semelhante à $A$. alatum, mas difere por apresentar apenas nervuras simples (vs. nervuras furcadas, em $A$. alatum). Espécie rupícola ou epífita, crescendo no interior da floresta, em locais sombreados e úmidos.

Material selecionado examinado: Mazziero et al. 979 (UPCB); Mazziero 1063 (UPCB).

2.3. Asplenium auriculatum Sw., Kongl. Vetensk. Acad. Handl. 1817(1): 68. 1817.

Espécie semelhante à Asplenium salicifolium L., mas é distinta por apresentar pinas laterais com nervuras, geralmente, simples e ápice da lâmina serreado, estreito, ligulado ou subcaudado (vs. nervuras predominantemente furcadas, ápice da lâmina conforme, com a porção basal alargada, em $A$. salicifolium) (Sylvestre, 2001). Espécie terrícola, encontrada no interior da floresta, em locais sombreados e úmidos.

Material selecionado examinado: Mazziero \& Albiero Jr. 1129 (UPCB).

2.4. Asplenium auritum Sw., J. Bot. (Schrader) 1800(2): 51. 1801.

Asplenium gastonis Fée é uma espécie semeIhante à $A$. auritum, diferindo pela lâmina mais dividida, 2-pinado-pinatífida a raro 3-pinada, pela lâmina membranácea e nervuras salientes (vs. 1-pinada-pinatissecta a 2-pinada, consistência coriácea da lâmina e nervuras imersas no tecido laminar, em A. auritum) (Sylvestre, 2001; 2010). Espécie terrícola ou epífita, crescendo em clareiras, em pontos ensolarados e úmidos.

Material selecionado examinado: Mazziero \& Soller 602 (UPCB, SP); Mazziero \& Soller 627 (UPCB).
2.5. Asplenium brasiliense Sw., Kongl. Vetensk. Acad. Handl. 1817(1): 65, t. 3, f. 4. 1817.

Pode ser separado de Asplenium douglasii Hook. \& Grev. e de Asplenium balansae (Baker) Sylvestre, por seu pecíolo ter $1 / 6$ a $1 / 20$ do tamanho da lâmina, com base longamente decurrente (vs. lâmina com base cordada ou cuneada e pecíolo com $1 / 2$ do tamanho da lâmina ou maior, em A. douglasii e A. balansae). (Sylvestre, 2001). Espécie rupícola ou terrícola, crescendo em trilhas e no interior da floresta, em locais sombreados e úmidos.

Material selecionado examinado: Mazziero \& Soller 842 (UPCB, RB); Mazziero et al. 942 (UPCB, SP, UNIP, NY, CAS).

2.6. Asplenium cirrhatum Rich. ex Willd., Sp. PI. 5: 321. 1810.

Asplenium cirrhatum apresenta lâmina 1-pinada, o que a separa das espécies: Asplenium radicans $\mathrm{L}$. que apresenta lâmina 1-pinada-pinatífida, 2-pinada em $A$. flabellulatum e 3-pinada em Asplenium uniseriale Raddi (Tryon \& Stolze, 1993; Sylvestre, 2001; Mickel \& Smith 2004). Espécie terrícola ou rupícola, encontrada no interior da floresta, em locais úmidos e sombreados.

Material selecionado examinado: Mazziero \& Soller 853 (UPCB, SP, UNIP, NY); Mazziero 1061 (UPCB).

2.7. Asplenium claussenii Hieron., Hedwigia 60: 241. 1918

Asplenium regulare Sw. diferencia-se desta espécie, principalmente, pela lâmina verde-escura quando seca, com contorno oblongo-lanceolado e ápice das pinas obtuso, enquanto, em $A$. claussenii, a lâmina torna-se verde-clara depois de seca, linear-lanceolada, com ápice das pinas agudo (Sylvestre, 2001). Espécie rupícola, encontrada no interior da floresta e nas trilhas, em locais secos e ensolarados.

Material selecionado examinado: Mazziero \& Soller 913 (UPCB, NY); Mazziero et al. 955 (UPCB, SP, UNIP); Mazziero et al. 966 (UPCB).

2.8. Asplenium cristatum Lam., Encycl. 2(1): 310. 1786 .

Separa-se das demais espécies brasileiras com lâmina 2-pinada (ou mais complexa) e pínulas basais das pinas proximais pecioluladas, por apresentar raque inteiramente alada, pinas formando ângulo de $90^{\circ} \mathrm{em}$ relação à raque e pelas pínulas basais acroscópicas sobrepondo a raque (Sylvestre, 2001). Espécie rupícola, encontrada 
no interior da floresta, em locais sombreados e úmidos nas entradas das cavernas.

Material selecionado examinado: Mazziero 1042 (UPCB).

2.9. Asplenium feei Kunze ex Fée, Mém. Foug. 5: 194.1852.

Espécie caracterizada, principalmente, pela presença de indúsio coriáceo e curvado em relação à nervura, além disso, a lâmina adquire coloração escurecida depois de seca, com consistência cartácea e pínula apical conforme (Sylvestre, 2001). Espécie terrícola, ocorrendo em pontos sombreados e úmidos, no interior da floresta.

Material selecionado examinado: Mazziero \& Albiero Jr. 1042 (UPCB, SP, UNIP).

\subsection{Asplenium flabellulatum Kunze, Linnaea} 9: 71.1834.

Espécie pertencente ao complexo de $A$. radicans e sua diferenciação das demais espécies é apresentada nos comentários de $A$. cirrhatum (item 2.6). Espécie terrícola, não observada em campo no presente estudo, mas segundo dados de coleta desta espécies para o Estado de São Paulo a encontraram, geralmente, em barrancos às margens de córregos (Splink, 2018).

Material selecionado examinado: BRASIL. São Paulo, Mun. Apiaí, s. d., J. J. Puiggari 812 (RB).

2.11. Asplenium harpeodes Kunze, Linnaea 18: 329. 1844[1845].

Difere de $A$. raddianum por apresentar caule com escamas lineares, castanho-escuras a nigrescentes, raque castanho-escura e pinas perpendiculares à raque (vs. escamas lanceoladas, castanho-acinzentadas, raque pardacenta e pinas curvadas e ascendentes, quando comparadas à raque, em $A$. raddianum) (Sylvestre, 2001). Espécie epífita, rupícola ou terrícola (Sylvestre, 2015), não registrada em campo no presente estudo, porém, dados de coleta da espécie no Estado de São Paulo, indicam sua ocorrência em ambientes de interior das florestas em locais sombreados (Splink, 2018).

Material selecionado examinado: BRASIL. São Paulo, Mun. Apiaí, s.d., J. J. Puiggari 629 (SP).

2.12. Asplenium kunzeanum Klotzsch ex Rosenst., Hedwigia 46: 100. 1906.

Difere de $A$. rosenstockianum por apresentar raque não estendendo-se além do último par de pinas e as nervuras são predominantemente furcadas (vs. raque estendendo-se além do último par de pinas e apenas as nervuras proximais furcadas, em $A$. rosenstockianum) (Sylvestre, 2001). Espécie terrícola ou rupícola, crescendo nas trilhas e no interior da floresta, em locais úmidos e sombreados.

Material selecionado examinado: Mazziero \& Soller 852 (UPCB); Mazziero \& Soller 866 (UPCB, CAS); Mazziero \& Soller 870 (UPCB, SP, UNIP, NY); Mazziero 1070 (UPCB, SP, UNIP, RB); Mazziero \& Albiero Jr. 1091 (UPCB).

2.13. Asplenium mucronatum C. Presl, Delic. Prag. 1: 178. 1872.

Esta espécie se assemelha à $A$. pteropus, no entanto, segundo Sylvestre (2001), nesta espécie, a lâmina é lanceolada, com pinas inteiras, serreadas nas margens e a ala é interrompida pela inserção das pinas, enquanto, em $A$. mucronatum, a lâmina é linear-lanceolada, as pinas são pinatífidas, com o ápice dos segmentos mucronado e a ala não é interrompida. Espécie epífita, observada no interior da floresta em locais sombreados e úmidos.

Material selecionado examinado: Mazziero \& Soller 659 (UPCB, CAS, NY); Mazziero et al. 963 (UPCB, SP, UNIP).

2.14. Asplenium oligophyllum Kaulf., Enum. Filc. 166.1824.

Espécie próxima de Asplenium austrobrasiliense (Christ) Maxon, no entanto, esta apresenta lobos arredondados na base das pinas medianas e escamas caulinares lanceoladas, nigrescentes (vs. pinas medianas com base cuneada e escamas oval-lanceoladas, castanho-claras, em $A$. oligophyllum) (Sylvestre, 2001). Espécie epífita, observada no interior da floresta, em locais sombreados.

Material selecionado examinado: Mazziero \& M.E. Engels 1140 (UPCB).

2.15. Asplenium pseudonitidum Raddi, Syn. Fil. Bras. n. 98. 1819.

Assemelha-se à Asplenium wacketii Rosenst., no entanto, seus soros medem 3-5 mm de comprimento, base da lâmina 2-pinada-pinatífida, com segmentos arredondados a obtusos e estipe, na maioria das vezes, com $2 / 3$ do comprimento da lâmina, enquanto, em $A$. wacketii, os soros apresentam 1-2,5 mm de comprimento, base da lâmina 3-pinada, com segmentos deltoides a alongados e pecíolo do mesmo tamanho ou maior que a lâmina (Sylvestre, 2001). Encontrada crescendo sobre troncos em decomposição, no interior da floresta, em locais úmidos e sombreados.

Material selecionado examinado: Mazziero \& Albiero Jr. (UPCB, SP, UNIP, NY).

2.16. Asplenium pteropus Kaulf., Enum. Fil.: 170. 1824.

Espécie semelhante à $A$. mucronatum (ver comentários desta, item 2.13). Espécie epífita, 
encontrada próxima aos córregos no interior da floresta, em locais sombreados.

Material selecionado examinado: Mazziero \& Soller 614 (UPCB, SP); Mazziero \& Soller 615 (UPCB); Mazziero et al. 950 (UPCB); Mazziero 1054 (UPCB, UNIP).

2.17. Asplenium raddianum Gaudch., Voy. Uranie 316. 1828.

Espécie semelhante à $A$. harpeodes e suas diferenças são mostradas nos comentários desta última (item 2.11). Espécie terrícola, encontrada em clareiras, no interior da mata.

Material selecionado examinado: Mazziero \& Soller 661 (UPCB); Mazziero \& Albiero Jr. 1101 (UPCB, SP, UNIP, NY).

2.18. Asplenium scandicinum Kaulf., Enum. Fil.: 177. 1824.

De acordo com Schwartsburd \& Labiak (2007), trata-se de uma espécie caracterizada pela lâmina 3-4-pinada, membranácea, glabra, além da porção distal do pecíolo verde, tornando-se castanho próximo à base. Espécie epífita, observada às margens de córregos, no interior da floresta.

Material selecionado examinado: Mazziero \& Soller 624 (UPCB, SP); Mazziero \& Soller 626 (UPCB, UNIP, CAS, NY).

2.19. Asplenium serra Langsd. \& Fisch., $\mathrm{Pl}$. Voy. Russes Monde 1: 16, t. 19. 1810.

De acordo com Sylvestre (2001), Asplenium incurvatum Fée é uma espécie semelhante à esta, distinguindo-se pela base assimétrica das pinas e escamas caulinares linear-lanceoladas, com ápice longo-caudado (vs. base das pinas simétricas e escamas do caule lanceoladas, com ápice atenuado, em $A$. serra). Espécie rupícola, crescendo ao longo das trilhas, em locais sombreados.
Material selecionado examinado: Mazziero \& A. Soller 838 (UPCB, SP).

2.20. Asplenium serratum L., Sp. Pl. ed. 2. 1709. 1753.

Dentre as espécies do Estado de São Paulo com lâmina simples, assemelha-se a Asplenium stuebelianum Hieron., porém, em $A$. serratum o pecíolo tem $1 / 10$ a $1 / 20$ do comprimento da lâmina, enquanto que, em $A$. stuebelianum, o pecíolo é longo, com $1 / 7$ a $1 / 2$ do comprimento da lâmina (Sylvestre, 2001). Espécie epífita, ocorrendo em locais sombreados e úmidos, no interior da floresta.

Material selecionado examinado: Mazziero \& Soller 587 (UPCB); Mazziero et al. 957 (UPCB, $\mathrm{SP})$.

2.21. Hymenasplenium triquetrum ( $\mathrm{N}$. Murak. \& R. C. Moran) L. Regalado \& Prada, Amer. Fern J. 101(4): 279. 2011 (2012).

Hymenasplenium laetum (Sw.) Regalado \& Prada é uma espécie semelhante à esta, diferindo por apresentar ápice da lâmina pinatífido e a costa sulcada na face adaxial, enquanto, $H$. triquetrum apresenta ápice subconforme e a costa proeminente na face adaxial (Murakami \& Moran, 1993). Espécie rupícola, encontrada às margens de córregos, em trilhas ou no interior da floresta, em locais sombreados.

Material selecionado examinado: Mazziero \& Soller 584 (UPCB, UNIP); Mazziero \& Soller 704 (UPCB, SP).

\section{ATHYRIACEAE}

1. Caule longo-reptante

$1^{\prime}$. Caule ereto.

2. Lâmina inteira

$2^{\prime}$. Lâmina 1-pinado-pinatífida ou mais complexa.

3. Tricomas presentes no tecido laminar entre as nervuras.

3'. Tricomas ausentes no tecido laminar entre as nervuras.

4. Lâmina 1-pinado-pinatífida.

4'. Lâmina 2-pinada ou mais complexa.

5. Indúsio plano, com a margem inteira.

5'. Indúsio bulado, com a margem fimbriada.

3.1. Deparia petersenii. 3.5. Diplazium plantaginifolium.

3.1. Deparia petersenii (Kunze) M. Kato, Bot. Mag. 90(1017): 37. 1977.

Única espécie do gênero no Brasil (Mynssen, 2015), sendo reconhecida por apresentar sulco da raque contínuo, não interrompido na inserção dos segmentos (Mynssen, 2011). Erva terrícola, encontrada em locais sombreados e úmidos, próximo às margens de riachos. 
Material selecionado examinado: Mazziero \& Soller 701 (UPCB).

3.2. Diplazium ambiguum Raddi, Syn. fil. bras. 3: 292. 1819.

Segundo Mynssen (2011), esta espécie assemelha-se à Diplazium striatum (L.) C. Presl que, no entanto, apresenta tecido laminar pubescente, o qual é glabro em $D$. ambiguum. Espécie terrícola, encontrada em locais sombreados e úmidos, ao longo de trilhas ou no interior da floresta.

Material selecionado examinado: Mazziero \& Soller 559 (UPCB, CAS); Mazziero \& Soller 850 (UPCB, SP, UNIP); Mazziero \& Soller 921 (UPCB, NY, CAS); Mazziero 1007 (UPCB, SP, UNIP).

3.3. Diplazium asplenioides (Kunze) C. Presl, Tent. Pterid. 114. 1836.

Espécie semelhante à $D$. striatum, porém, o indúsio é glabro e inteiro em $D$. striatum, enquanto, em $D$. asplenioides, o indúsio é fimbriado e com tricomas (Mynssen, 2011). Espécie terrícola encontrada crescendo nas trilhas, em locais sombreados e úmidos.

Material selecionado examinado: Mazziero \& Soller 696 (UPCB, SP).

3.4. Diplazium cristatum (Desr.) Alston, J. Bot. 74: 173. 1936.

Deparia petersenii assemelha-se à D. cristatum, contudo, D. petersenii apresenta caule Ion- go-reptante e ambas as faces pilosas, diferentemente de $D$. cristatum, com caule ereto e lâmina glabra (Cislinsk, 1996). Espécie terrícola ou rupícola, observada em locais ensolarados e úmidos, nas trilhas e às margens de córregos.

Material selecionado examinado: Mazziero \& Soller 695 (UPCB, SP); Mazziero et al. 932 (UPCB, UNIP).

\subsection{Diplazium plantaginifolium (L.) Urb.,} Symb. Antill. 4: 31. 1903.

Espécie facilmente separada das demais do gênero, verificadas para o Estado de São Paulo, pela presença de lâmina inteira. Espécie terrícola encontrada, geralmente, no interior da floresta em locais sombreados (Mynssen, 2011; 2015).

Material selecionado examinado: BRASIL. São Paulo, Mun. Ribeira, III.1911, A. C. Brade $5161(\mathrm{NY})$.

3.6. Diplazium turgidum Rosenst., Hedwigia 46: 109. 1907.

Segundo Mynssen (2011), esta espécie se assemelha à Diplazium leptocarpon Fée devido à presença de indúsio fimbriado. Entretanto, D. turgidum apresenta a margem das escamas inteiras e maior porte (Mynssen, 2011). Espécie terrícola, encontrada em locais sombreados e úmidos, às margens de córregos.

Material selecionado examinado: Mazziero \& Soller 815 (UPCB, NY, CAS); Mazziero \& Soller 922 (UPCB, SP, UNIP).

\section{BLECHNACEAE}

1. Lâmina 2-pinada; frondes de crescimento indeterminado 4.11. Salpichlaena volubilis.

$1^{\prime}$. Lâmina pinatissecta a 1-pinada; frondes de crescimento determinado.

2. Frondes monomorfas.

3. Caule longo-reptante; lâmina pinada, pinas articuladas à raque..4.12. Telmatoblechnum serrulatum.

3'. Caule curto-reptante, ereto ou arborescente; lâmina pinatissecta próximo ao ápice, pinas não articuladas à raque.

4. Caule ereto e massivo (subarborescente); base do pecíolo com escamas nigrescentes, lineares, com $1,5 \mathrm{~cm}$ de comprimento ou maiores.......................................4.9. Neoblechnum brasiliense. $4^{\prime}$. Caule curto-reptante a ereto, delgado (nunca de aspecto arborescente); escamas da base do pecíolo castanhas, lanceoladas a deltoides, com até $1 \mathrm{~cm}$ de comprimento.

5. Lâmina linear-lanceolado; pinas basais gradualmente reduzidas a aurículas ou lobos semicirculares. 4.5. Blechnum polypodioides.

5'. Lâmina deltoide; pinas basais não reduzidas.

6. Ápice da lâmina subconforme; base basioscópica das pinas proximais cuneada....................................................................4.3. Blechnum ${ }^{x}$ caudatum.

6'. Ápice da lâmina pinatissecto; base basioscópica das pinas proximais corda-

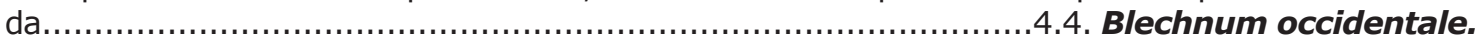

$2^{\prime}$. Frondes dimorfas.

7. Caule ereto, robusto (subarborescente); escamas do caule e base do pecíolo com mais de $1,5 \mathrm{~cm}$ de comprimento, lineares a linear-lanceoladas....

4.8. Lomariocycas schomburgkii.

$7^{\prime}$. Caule ereto, delgado (nunca subarborescente), decumbente ou longo-reptante; escamas do caule e base do pecíolo com menos de $1 \mathrm{~cm}$ de comprimento, lanceoladas a deltoides.

8. Lâmina estéril, nitidamente 1-pinada ao menos na base.................4.10. Parablechnum cordatum. 8'. Lâmina estéril, inteiramente pinatissecta.

9. Base da lâmina truncada. 4.6. Cranfillia sampaioana.

9'. Base da lâmina gradualmente ou abruptamente reduzida. 
10. Base da lâmina gradualmente reduzida. 4.2. Austroblechnum lehmannii.

10'. Base da lâmina abruptamente reduzida.

11. Plantas hemiepífitas; caule longo-reptante.

4.7. Lomaridium plumieri.

$11^{\prime}$. Plantas terrícolas; caule ereto. 4.1. Austroblechnum divergens.

4.1. Austroblechnum divergens (Kunze) Gasper \& V. A. O. Dittrich, Phytotaxa 275(3): 202. 2016.

Apresenta escamas do caule castanho-claras, foscas, pecíolo das frondes estéreis com mais de $2,7 \mathrm{~mm}$ de diâmetro, frondes estéreis com $71 \mathrm{x}$ $13 \mathrm{~cm}$ e 4-8 pares de pinas vestigiais (Dittrich et al., 2017). É uma espécie semelhante à Austroblechnum organense (Brade) V .A. O. Dittrich, mas esta possui escamas do caule nigrescentes, brilhantes, diâmetro do pecíolo até $1,9 \mathrm{~mm}$, dimensão de $31 \times 12 \mathrm{~cm}$ das frondes estéreis e pinas vestigiais entre 0-3 pares (Dittrich et al., 2017). Espécie terrícola, habitando locais sombreados e úmidos, no interior da floresta.

Material selecionado examinado: Mazziero \& Albiero Jr. 1111 (UPCB, SP, UNIP).

4.2. Austroblechnum lehmannii (Kunze) Gasper \& V. A. O. Dittrich, Phytotaxa 275(3): 203. 2016.

Difere de Austroblechnum squamipes (Hieron.) Gasper \& V. A. O. Dittrich por apresentar lâmina estéril maior que $4 \mathrm{~cm}$ de largura, pelo caule longo (maior que $20 \mathrm{~cm}$ ), decumbente, pecíolo predominantemente paleáceo e escamas caulinares lanceoladas (Dittrich et al., 2017). Já, $A$. squamipes, apresenta lâmina estéril menor que $3,5 \mathrm{~cm}$ de largura, caule ereto e curto, menor que $5 \mathrm{~cm}$, pecíolo predominantemente atropurpúreo e escamas do caule oval-lanceoladas (Dittrich et al., 2017). Espécie terrícola, encontrada em locais úmidos e sombreados no interior da floresta.

Material selecionado examinado: Mazziero \& Albiero Jr. 1131 (UPCB, SP, UNIP, NY, CAS).

4.3. Blechnum ${ }^{\times}$caudatum Cav., Descr. PI. 262. 1802.

De acordo com Moran (1995a), trata-se de um híbrido entre Blechnum gracile Kaulf. e $B$. occidentale. Pode ser segregado de seus parentais por apresentar mais de sete pares de pina, lâmina pinatissecta próximo ao ápice, pina apical surcurrente, pina basal basioscopicamente cuneada e ápice da lâmina subconforme (Dittrich et al., 2015). Espécie terrícola, observada nas trilhas, em locais sombreados.

Material selecionado examinado: Mazziero \& Soller 610 (UPCB, SP, UNIP, NY).

4.4. Blechnum occidentale L., Sp. PI. 1077. 1753.
Separa-se de Blechnum austrobrasilianum de la Sota e Blechnum laevigatum Cav., por apresentar o par de pinas proximal acroscópicamente livre, sendo este completa ou parcialmente soldado nas duas outras espécies (Dittrich et al., 2015). Espécie terrícola, encontrada em locais sombreados e úmidos, ás margens das estradas e trilhas.

Material selecionado examinado: Mazziero \& Soller 580 (UPCB, SP, UNIP); Mazziero \& Soller 691 (UPCB).

4.5. Blechnum polypodioides Raddi, Opusc. Sci. Bol. 3: 294. 1819.

Blechnum asplenioides Sw. é semelhante à esta espécie, porém, suas pinas medianas são deltoides, ascendentes e as basais semicirculares, por sua vez, em $B$. polypodioides, as pinas medianas são estreitamente triangulares e patentes, ou pouco ascendentes, e as pinas basais são surcurrentes (Dittrich et al., 2015). Espécie terrícola ou rupícola, habitando desde locais sombreados até ambientes expostos ao sol, em barrancos, borda e interior da floresta.

Material selecionado examinado: Mazziero \& Soller 577 (UPCB); Mazziero \& Soller 653 (UPCB, SP, UNIP); Mazziero \& Soller 821 (UPCB, NY, CAS).

4.6. Cranfillia sampaioana (Fée) V. A. O. Dittrich \& Gasper, Phytotaxa 303(1): 15. 2017.

Além desta espécie, no Brasil, ocorre também Cranfillia caudata (Baker) V. A. O. Dittrich \& Gasper, reconhecida pela lâmina com o ápice e a base gradualmente reduzidos, sendo o ápice flageliforme (vs. lâmina com ápice reduzido, pinatífido e base truncada, em C. sampaioana) (Dittrich et al., 2017). Espécie terrícola, ocorrendo em ambientes sombreados e úmidos, no interior da floresta.

Material selecionado examinado: Mazziero \& Albiero Jr. 1097 (UPCB, NY); Mazziero \& Albiero Jr. 1128 (UPCB, SP, UNIP).

4.7. Lomaridium plumieri (Desv.) Presl, Abh. Königl. Böhm. Ges. Wiss., 5: 515. 1851.

De acordo com Dittrich et al. (2017), trata-se de um gênero com apenas uma espécie na região sudeste e, separa-se das demais espécies da família Blechnaceae com frondes dimorfas desta região, por apresentar caule longo-reptante, com escamas de margem denteada com a porção central negra. Espécie hemiepífita ou epífita, mas 
com alguns indivíduos jovens encontrados como terrícolas, ocorre em locais sombreados, no interior da floresta e trilhas.

Material selecionado examinado: Mazziero \& Soller 612 (UPCB, SP); Mazziero \& Soller 617 (UPCB, UNIP, NY).

4.8. Lomariocycas schomburgkii (Klotzsch) Gasper \& A. R. Sm., Phytotaxa 275(3): 213. 2016.

No Brasil este gênero apresenta apenas uma espécie (Dittrich \& Salino, 2015). Pode ser reconhecida por apresentar lâmina coriácea, com nervuras não proeminentes, pina apical não surcurrente e costa não sulcada (Dittrich et al., 2017). Espécie terrícola, crescendo em locais úmidos a pleno sol, geralmente às margens de riachos ou bordas da floresta.

Material selecionado examinado: Mazziero \& Albiero Jr. 1132 (UPCB, SP, UNIP, NY).

4.9. Neoblechnum brasiliense (Desv.) Gasper \& V. A. O. Dittrich, Phytotaxa 275(3): 214. 2016.

Separa-se das demais espécies da família Blechnaceae da região sudeste, pela presença de escamas nigrescentes na base do pecíolo, lineares, geralmente, maiores que $1-1,5 \mathrm{~cm}$ de comprimento e caule subarborescente (Dittrich et al., 2017). Espécie terrícola, ocorre às margens de regatos e estradas, em locais sombreados e úmidos.

Material selecionado examinado: Mazziero \& Soller 655 (UPCB, SP, UNIP).

4.10. Parablechnum cordatum (Desv.) Gasper \& Salino, Phytotaxa 275(3): 216. 2016.

Difere das demais espécies do gênero encontradas no Brasil, por não apresentar gemas nas pinas distais (vs. presentes, em Parablechnum proliferum Gasper \& Salino), apresentar caule ereto ou decumbente (vs. longo-reptante, em Parablechnum usterianum (Christ) Gasper \& Salino) e por possuir pinas com base cordada ou subcordada (vs. pinas com base cuneada, em Parablechnum glaziovii (Christ) Gasper \& Salino) (Dittrich, 2005). Espécie terrícola, habitando locais expostos ao sol, como a borda da floresta e barrancos às margens das estradas.

Material selecionado examinado: Mazziero \& Soller 692 (UPCB, SP, UNIP, NY, CAS).

4.11. Salpichlaena volubilis (Kaulf.) J. Sm., J. Bot. (Hooker) 4: 168. 1842.

Salpichlaena hookeriana (Kuntze) Alston é a única outra espécie do gênero, distinguindo-se de S. volubilis por possuir lâmina com tricomas glandulares, escamas costais ovais com margem denteado-glandular e apresentar gemas na axila das pinas estéreis (em S. volubilis, não há tricomas glandulares no tecido laminar, as escamas costais são lanceoladas com margem ciliado-glandular e não ocorrem gemas nas axilas das pinas (Giudice et al., 2008). Espécie volúvel, encontrada no interior da floresta, clareiras e borda da floresta, em locais ensolarados e úmidos.

Material selecionado examinado: Mazziero \& Soller 648 (UPCB, SP, UNIP, NY, CAS); Mazziero \& Soller 827 (UPCB).

4.12. Telmatoblechnum serrulatum (Rich.) Pierre, D. J. Ohlsen \& Brownsey, Taxon 63(4): 755. 2014.

Espécie com as pinas articuladas à raque, separada, assim, das demais espécies de Blechnaceae da região sudeste. Espécie terrícola, observada na borda da floresta, exposta ao sol e em solo encharcado.

Material selecionado examinado: Mazziero \& Soller 843 (UPCB, SP, UNIP).

\section{CYATHEACEAE}

1. Escamas da base dos pecíolos com uma seta negra no ápice.

2. Base do pecíolo com aflébias; lâmina com ápice gradual ou abruptamente reduzido, mas não conforme..... 5.1. Alsophila setosa.

2'. Base do pecíolo sem aflébias; lâmina com ápice conforme. 5.2. Alsophila sternbergii.

$1^{\prime}$. Escamas da base dos pecíolos sem seta negra no ápice.

3. Base do pecíolo com escamas ferrugíneas.

4. Soros com indúsio globoso.

4'. Soros sem indúsio.

5. Lâmina com ápice conforme.

$5^{\prime}$. Lâmina com ápice pinatífido.

5.5. Cyathea delgadii.

6. Nervuras secundárias predominantemente simples; paráfises menores ou do mesmo tamanho dos esporângios; escamas buladas alvas, esparsas sobre a costa e cóstula; espinhos do pecíolo e raque entre 3-7 mm de comprimento.....................................................5.3. Cyathea atrovirens.

6'. Nervuras secundárias predominantemente furcadas; paráfises maiores que os esporângios; escamas buladas alvas revestindo densamente a costa e cóstula; espinhos do pecíolo e raque entre $1-3 \mathrm{~mm}$ de comprimento. 5.8. Cyathea phalerata.

3'. Base do pecíolo com escamas alvas ou estramíneas.

7. Margem das escamas da base do pecíolo sem dentes nigrescentes. 5.7. Cyathea leucofolis.

7'. Margem das escamas da base do pecíolo com dentes nigrescentes......... 5.6. Cyathea hirsuta. 
5.1. Alsophila setosa Kaulf., Enum. Fil. 249. 1824.

A espécie brasileira mais semelhante à $A$. setosa é Alsophila capensis (L. f.) J. Sm., contudo, apresenta aflébias sem expansões laminares e nervuras secundárias simples (Schwartsburd \& Labiak, 2007), enquanto, em $A$. setosa, as aflébias apresentam tecido laminar e nervuras secundárias ramificadas. Espécie arborescente, encontrada interior da floresta e ao longo de trilhas, em locais sombreados e úmidos.

Material selecionado examinado: Mazziero \& Soller 881 (UPCB, SP, UNIP).

5.2. Alsophila sternbergii (Sternb.) D. S. Conant, J. Arnold Arbor. 64(3): 371. 1983.

Alsophila cuspidata (Kunze) D. S. Conant é a espécie mais semelhante à esta, mas distingue-se por apresentar indúsio avermelhado, quase negro, opaco, dividindo-se em três partes iguais, por sua vez, em $A$. sternbergii, o indúsio é castanho, esbranquiçado a marrom, brilhante, dividindo-se em fragmentos irregulares (Weigand \& Lehnert, 2016). Espécie arborescente, observada próxima a córregos, no interior da floresta e nas trilhas, em locais sombreados e úmidos.

Material selecionado examinado: Mazziero \& Soller 637 (UPCB, SP, UNIP).

5.3. Cyathea atrovirens (Langsd. \& Fisch.) Domin, Pteridophyta 262. 1929.

De acordo com Fernandes (1997), C. atrovirens pode ser confundida com Cyathea villosa Willd., contudo, a segunda apresenta escamas da base do pecíolo com margem hialina estreita e ápice helicoidalmente torcido, além de pinas ascendentes (vs. escamas concolores, de ápice não torcido e pinas patentes ou quase, em $C$. atrovirens). Espécie arborescente, encontradas em locais ensolarados, como beira de estradas, trilhas, às margens de córregos ou no interior da floresta.

Material selecionado examinado: Mazziero \& Soller 860 (UPCB, SP, UNIP); Mazziero \& Albiero Jr. 1103 (UPCB, NY, CAS).

5.4. Cyathea corcovadensis (Raddi) Domin, Pteridophyta 262, 1929.

Espécie com lâmina bipinada, ápice conforme, pínulas inteiras a levemente lobadas, cerca de cinco vezes mais compridas que largas e soros mediais a inframediais (Weigand \& Lehnert, 2016), o que a separa das espécies do gênero encontradas no Estado de São Paulo. Espécie arborescente, encontrada nas trilhas ou no interior da floresta, em locais úmidos e sombreados.

Material selecionado examinado: Mazziero \& Soller 686 (UPCB, SP, UNIP); Mazziero et al. 946 (UPCB).
5.5. Cyathea delgadii Sternb., Vers. Fl. Vorwelt 1: 47 , t. B. 1820.

C. delgadii apresenta indúsio abrangendo todo o receptáculo e lâmina 2-pinado-pinatífida (Weigand \& Lehnert, 2016), o que a difere das demais espécies encontradas no Estado de São Paulo. Espécie arborescente, encontrada em clareiras, bordas, trilhas e no interior da floresta, em locais sombreados ou ensolarados, úmidos.

Material selecionado examinado: Mazziero \& Albiero Jr. 1109 (UPCB, SP, UNIP).

5.6. Cyathea hirsuta C. Presl, Delic. Prag. 190. 1822.

Separa-se de Cyathea rufa (Fée) Lellinger por apresentar escamas nitidamente bicolores, ao menos às da base do pecíolo, com dentículos negros nas margens (vs. escamas concolores, com a margem desprovida de dentes ou poucos e marrons, em C. rufa) (Weigand \& Lehnert, 2016). Espécie arborescente, crescendo em trilhas, margens de estradas e córregos, em locais sempre ensolarados.

Material selecionado examinado: Mazziero \& Soller 882 (UPCB, NY, CAS); Mazziero et al. 986 (UPCB, SP, UNIP).

5.7. Cyathea leucofolis Domin, Pteridophyta 262. 1929.

Pode ser reconhecida por apresentar escamas, geralmente, concolores e alvas, receptáculos nunca subtendidos por escâmulas subuladas e paráfises menores ou do mesmo tamanho que os esporângios (Weigand \& Lehnert, 2016). Espécie arborescente, habitando o interior da floresta, em locais úmidos e sombreados.

Material selecionado examinado: Mazziero \& Soller 858 (UPCB, SP, UNIP).

5.8. Cyathea phalerata Mart., Denkschr. Bayer. Bot. Ges. Regensberg. 2: 146, t. 2, f. 3. 1822.

Assemelha-se à C. delgadii, mas esta apresenta indúsio globoso (vs. soros exindusiados, em C. phalerata); pode também ser confundida com C. villosa, mas esta apresenta as escamas da base do pecíolo ferrugíneas, com margem hialina e ápice helicoidalmente torcido, além de pinas ascendentes (cerca de $45^{\circ}$ em relação à raque), diferentemente de C. phalerata, em que as escamas são inteiramente ferrugíneas, com ápice não torcido e pinas quase patentes (Fernandes, 1997). Espécie arborescente, ocorre próximo aos córregos, trilhas e no interior da floresta, em locais sombreados.

Material selecionado examinado: Mazziero \& Soller 636 (UPCB); Mazziero \& Soller 656 (UPCB, NY, CAS); Mazziero \& Soller 856 (UPCB, $\mathrm{SP}, \mathrm{UNIP})$.

Rev. Biol. Neotrop. / J. Neotrop. Biol., Goiânia, v. 15, n. 1, p. 22-72, jan.-jun. 2018 


\section{DENNSTAEDTIACEAE}

1. Duas ou mais nervuras por soro. 6.8. Pteridium arachnoideum.

$1^{\prime}$. Uma única nervura por soro.

2. Pecíolo e raque muricados ou com acúleos.

3. Pecíolo e raque com acúleos conspícuos, maiores que $1,5 \mathrm{~mm}$ de comprimento; porção distal do pecíolo e raque castanho-claros a castanho-escuros..........................................6.6. Hypolepis acantha.

3'. Pecíolo e raque com acúleos inconspícuos, menores que $1 \mathrm{~mm}$ de comprimento; porção distal do pecíolo e raque estramíneos. 6.7. Hypolepis mitis. $2^{\prime}$. Pecíolo e raque inermes.

4. Caule densamente revestido por tricomas avermelhados; ala dos penúltimos segmentos decurrente aos segmentos terminais 6.4. Dennstaedtia globulifera.

4'. Caule glabro ou, se revestido por tricomas, então esses são hialinos a alvos; ala dos penúltimos segmentos não decurrente aos segmentos terminais.

5. Indúsios com cerca de 1-2 mm de largura, mais largos do que longos; ápice do caule ascendente...

6.2. Dennstaedtia cornuta.

5'. Indúsios com no máximo $1 \mathrm{~mm}$ de largura, tão largos quanto longos; ápice do caule prostrado ou subterrâneo.

6. Pínulas pecioluladas, sendo as basais acroscópicas mais desenvolvidas que as basioscópicas.

6.1. Dennstaedtia cicutaria.

6'. Pínulas sésseis, sendo as basais acroscópicas menos desenvolvidas que as basioscópicas.

7. Lâmina 2-pinado-pinatífida; ápice dos últimos segmentos arredondado e crenado..... 6.5. Dennstaedtia obtusifolia.

7'. Lâmina 3-pinado-pinatífida (ao menos na base); ápice dos últimos segmentos truncado e denticulado. 6.3. Dennstaedtia dissecta.

6.1. Dennstaedtia cicutaria (Sw.) T. Moore, Index Fil. 97. 1857.

Pode ser separada de $D$. dissecta e D. globulifera por estas duas apresentarem as pínulas basais acroscópicas menores que as basioscópicas, enquanto, em $D$. cicutaria, as pínulas basais são maiores no lado acroscópico (Navarrete \& $\varnothing$ Ølgaard, 2000). Espécie terrícola, encontrada na borda da floresta e margens de estradas, em locais a pleno sol até pontos sombreados no interior da floresta.

Material selecionado examinado: Mazziero \& Soller 598 (UPCB, SP); 9.IV.2012, Mazziero 1042 (UPCB, UNIP, NY); Mazziero 1047 (UPCB); Mazziero \& Albiero Jr. 1118 (UPCB, CAS).

6.2. Dennstaedtia cornuta (Kaulf.) Mett., Ann. Sci. Nat., Bot., sér. 5, 2: 260. 1864.

De acordo com Navarrete \& Øllgaard (2000), esta espécie não apresenta raízes na base do pecíolo, o caule é longo-reptante com ápice ascendente, além de apresentar frondes férteis 3-pinado-pinatissectas a 4-pinadas e soros com 1-2 mm de largura, geralmente mais largos que compridos. Espécie terrícola, observada nas triIhas, em locais sombreados e úmidos.

Material selecionado examinado: Mazziero \& Albiero Jr. 1102 (UPCB, SP, UNIP).

6.3. Dennstaedtia dissecta (Sw.) T. Moore, Index Fil. 305. 1861.

Assemelha-se à $D$. obtusifolia, mas esta apresenta lâmina 2-pinado-pinatífida, segmen- tos terminais oblongos com ápice arredondado e crenado, além de soros com 1-1,2 mm de comprimento, enquanto, em $D$. dissecta, a lâmina é 3-pinado-lobada, os últimos segmentos são oblongos com ápice truncado e denticulado e os soros têm 0,8-1 mm de comprimento (Navarrete \& Øllgaard, 2000). Espécie terrícola, observada às margens de córregos, em locais sombreados e úmidos.

Material selecionado examinado: Mazziero \& Soller 816 (UPCB, SP, UNIP); Mazziero 990 (UPCB, NY, CAS).

6.4. Dennstaedtia globulifera (Poir.) Hieron., Bot. Jahrb. Syst. 34. 455. 1904.

Separa-se das demais espécies do gênero no Estado de São Paulo pelos caracteres apresentados na chave. Espécie terrícola, cresce em locais úmidos e sombreados, especialmente às margens de córregos.

Material selecionado examinado: Mazziero \& Soller 660 (UPCB).

6.5. Dennstaedtia obtusifolia (Willd.) T. Moore, Index Filic. 306. 1861.

Semelhante à $D$. dissecta, mas distingue-se pelas características apresentadas nos comentários referentes à mesma (item 6.3). Espécie terrícola, encontrada no interior da floresta, em locais sombreados e úmidos.

Material selecionado examinado: Mazziero \& Albiero Jr. 1106 (UPCB, SP). 
6.6. Hypolepis acantha Schwartsb., Kew Bull. 67(4): 816-818, f. 1A-C, 3A-B, map. 1. 2012.

Espécie semelhante à $H$. mitis, da qual difere pela presença conspícua de acúleos no pecíolo e raque, ambos desprovidos de tubérculos, tecido laminar hirsuto, tricomas aciculares e eretos (vs. pecíolo e raque com tubérculos e acúleos esparsos, tecido laminar estrigoso, tricomas esparsos, decumbentes e catenado-aciculares, em $H$. mitis) (Schwartsburd \& Prado, 2015). Espécie terrícola, encontrada nas trilhas, em pontos sombreados e úmidos.

Material selecionado examinado: Mazziero \& Albiero Jr. 1117 (UPCB, SP, UNIP, NY).

6.7. Hypolepis mitis Kunze ex Kuhn, Linnea 36: 105. 1869.
Assemelha-se à $H$. acantha, da qual difere pelas características apresentadas nos comentários referentes à mesma (item 6.6). Espécie terrícola, encontrada em local ensolarado, na margem de córrego.

Material selecionado examinado: Mazziero \& Soller 909 (UPCB).

6.8. Pteridium arachnoideum (Kaulf.) Maxon, J. Wash. Acad. Sci. 14: 89. 1924.

A única outra espécie do gênero no Brasil é Pteridium caudatum (L.) Maxon que, segundo Tryon \& Stolze (1989b), não apresenta lobos nos segmentos terminais, os quais estão presentes em $P$. arachnoideum. Espécie terrícola, encontrada às margens das estradas, exposta ao sol, formando grandes populações.

Material selecionado examinado: Mazziero \& Soller 689 (UPCB).

\section{DICKSONIACEAE}

1. Face abaxial da lâmina glauca; soros abaxiais, sem indúsio

$1^{\prime}$. Face abaxial da lâmina não glauca; soros marginais, com indúsio.

7.2. Lophosoria quadripinnata. 7.1. Dicksonia sellowiana.

7.1. Dicksonia sellowiana Hook., Sp. Fil. 1: 67. 1844.

Trata-se de uma espécie morfologicamente muito variável (Tryon \& Tryon, 1982). No entanto, é a única do gênero no Brasil (Condack, 2015) e pode ser reconhecida pelos caracteres apresentados na chave. Planta arborescente, encontrada nas encostas à beira das estradas, em locais sombreados.

Material selecionado examinado: Mazziero \& Soller 684 (UPCB, SP).

7.2. Lophosoria quadripinnata (J. F. Gmel.) C. Chr. in Skottsb., Nat. Hist. Juan Fernández 2: 16. 1920.

Difere das demais espécies de Dicksoniaceae e também de Cyatheaceae pela ausência de escamas no caule e na base do pecíolo, possuindo apenas tricomas, além da ausência de indúsio e face abaxial da lâmina glauca (Riba, 1995). Espé- cie terrícola, crescendo em barrancos sombreados e úmidos.

Material selecionado examinado: Mazziero \& Soller 920 (UPCB, SP, UNIP, NY); Mazziero \& A/biero Jr. 1108 (UPCB, SP, RB, CAS).

\section{DIDYMOCHLAENACEAE}

8.1. Didymochlaena truncatula (Sw.) J. Sm., J. Bot. (Hooker) 4: 196. 1841.

Única espécie do gênero e pode ser reconhecida por apresentar pínulas dimidiadas, hidatódios presentes no ápice das nervuras, soros lineares, revestidos por indúsio aderido à nervura pela porção central, expondo os esporângios de ambos os lados (Garcia \& Salino, 2008). Espécie terrícola, encontrada no interior da floresta ou em trilhas, em locais úmidos e sombreados.

Material selecionado examinado: Mazziero \& Soller 562 (UPCB).

\section{DRYOPTERIDACEAE}

1. Frondes dimorfas.

2. Lâmina estéril inteira.

3. Nervuras ligando-se a uma nervura coletora marginal.

$3^{\prime}$. Nervuras livres.

4. Pecíolo com escamas subuladas.

5. Escamas do pecíolo castanho-claras; frondes férteis não ultrapassando a 1/2 do tamanho das frondes estéreis. 9.8. Elaphoglossum glaziovii.

5'. Escamas do pecíolo marrom-avermelhadas a nigrescentes; frondes férteis do mesmo tamanho ou sutilmente maiores que as frondes estéreis.

4'. Pecíolo desprovido de escamas subuladas. 
6. Caule longo-reptante.

7. Ápice da lâmina arredondado a obtuso; escamas do caule nigrescentes.............................................................................10. Elaphoglossum lingua.

7'. Ápice da lâmina agudo; escamas do caule castanho-claras...........9.16. Elaphoglossum vagans.

6'. Caule curto-reptante ou ereto.

8. Pecíolo, costa e tecido laminar densamente escamosos; escamas ciliadas, sendo as do pecíolo e as da costa marrom-avermelhadas e as do tecido laminar castanho-claras........

9.15. Elaphoglossum strictum.

8'. Pecíolo, costa e tecido laminar glabrescentes (se escamosos, então com escamas inteiras ou apenas levemente denticuladas); escamas, quando presentes, de coloração parecida no pecíolo, costa e tecido laminar.

9. Lâmina estéril oblanceolada, com a porção mais larga maior que $5 \mathrm{~cm}$.

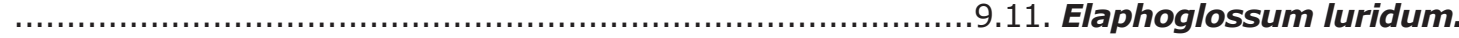

9'. Lâmina estéril linear, lanceolada ou oval, com a porção mais larga menor que $4 \mathrm{~cm}$.

10. Lâmina estéril com a base cuneada e contorno oval-lanceolado; pecíolo das frondes estéreis com $1 / 3$ ou mais do tamanho da fronde.

9.9. Elaphoglossum iguapense.

10'. Lâmina estéril com base atenuada e contorno linear-lanceolado; pecíolo das frondes estéreis com $1 / 5$ ou menos do tamanho da fronde.

11. Caule densamente escamoso; lâmina coriácea, com margem revoluta...................................................................... . Elaphoglossum glabellum.

11'. Caule glabrescente; lâmina cartácea, com margem plana.................................................................13. Elaphoglossum nigrescens.

2'. Lâmina estéril 1-pinada ou mais complexa.

12. Lâmina estéril 3-pinado-pinatífida................................................9.24. Polybotrya cylindrica.

12'. Lâmina estéril 1-pinada.

13. Nervuras anastomosadas desde a costa.

9.21. Mickelia scandens.

13'. Nervuras livres até próximo à margem, onde se unem a uma nervura coleto-

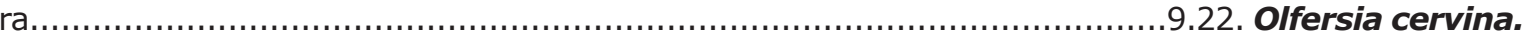

$1^{\prime}$. Frondes monomorfas.

14. Lâmina 1-pinada a 1-pinado-pinatissecta.

15. Caule curto-reptante; tecido laminar com glândulas translúcidas.

16. Incisões das pinas ultrapassando $2 / 3$ da distância entre a costa e a margem; segmentos com 9-13 pares de nervuras; sinus em forma de " $\mathrm{U} "$....................................9.27. Stigmatopteris caudata.

16'. Incisões das pinas nunca ultrapassando $1 / 2$ da distância entre a costa e a margem; segmentos com 3-6 pares de nervuras; sinus em forma de "V".

17. Incisões atingindo $1 / 4$ da distância entre a margem e a costa..9.28. Stigmatopteris heterocarpa.

$17^{\prime}$. Incisões atingindo $1 / 3$ da distância entre a margem e a costa...9.26. Stigmatopteris brevinervis.

15'. Caule ereto; tecido laminar sem glândulas translúcidas.

18. Ápice da lâmina conforme....

9.2. Ctenitis aspidioides.

$18^{\prime}$. Ápice da lâmina pinatífido.

19. Incisões da pina nunca ultrapassando $1 / 2$ da distância entre a costa e a margem; 2-3 nervuras por segmento atingindo o sinus............................................................9.5. Ctenitis pedicellata.

$19^{\prime}$. Incisões da pina geralmente ultrapassando $2 / 3$ da distância entre a costa e a margem; 1 nervura por segmento atingindo o sinus.

20. Escamas da costa e cóstula oval-deltoides, com a base cordada e ciliada, alvas, às vezes com o ápice mais escurecido....................................................................1. Ctenitis anniesii.

20 '. Escamas da costa e cóstula linear-lanceoladas a lanceoladas, com a base truncada, inteira a denticulada, sem cílios, amarelo-douradas a avermelhadas ou castanho-escuras a nigrescentes.

21. Caule com escamas rijas, castanho-escuras a nigrescentes, menores que $1,5 \mathrm{~cm}$ de comprimento.................................................................................... 9.4. Ctenitis falciculata.

$21^{\prime}$. Caule com escamas macias, amarelas, douradas ou marrom-alaranjadas, maiores que $1,5 \mathrm{~cm}$ de comprimento.

22. Tricomas glandulares ausentes no tecido laminar; escamas da costa e cóstula amarelas, alaranjadas ou avermelhadas; indúsios ausentes ou inconspícuos.....9.6. Ctenitis submarginalis.

22 '. Tricomas glandulares presentes no tecido laminar; escamas da costa e cóstula castanho-escuras; indúsios presentes. 9.3. Ctenitis distans.

14'. Lâmina 2-pinada ou mais complexa.

23. Caule ereto; primeira nervura basioscópica surgindo da costa.

24. Superfície abaxial da lâmina com tricomas glandulares; raque e raquíola conspicuamente escamosas, com escamas lanceoladas castanhas......................................... 9.20. Megalastrum umbrinum.

24 '. Tricomas glandulares ausentes; raque e raquíola sem escamas ou, se presentes, filiformes, inconspícuas, alaranjadas a castanho-claras.

25. Tecido laminar abaxial pubescente entre as nervuras.

9.18. Megalastrum albidum.

Rev. Biol. Neotrop. / J. Neotrop. Biol., Goiânia, v. 15, n. 1, p. 22-72, jan.-jun. 2018 
$25^{\prime}$. Tecido laminar abaxial glabro entre as nervuras 9.19. Megalastrum connexum. 23'. Caule curto a longo-reptante; primeira nervura basioscópica surgindo da cóstula.

26. Sulco da raque glabro; indúsio peltado. 9.25. Rumohra adiantiformis. 26 '. Sulco da raque pubescente; indúsio ausente ou reniforme.

27. Gemas presentes na porção distal da lâmina; indúsio ausente.....9.23. Parapolystichum effusum.

27 '. Gemas ausentes; indúsio presente. 9.17. Lastreopsis amplissima.

9.1. Ctenitis anniesii (Rosenst.) Copel., Gen. Fil. (Copeland) 124. 1947.

Ctenitis anniesii apresenta a margem das escamas da cóstula e costa inteira ou levemente denteada, às vezes, a porção basal com alguns cílios (Christensen, 1913). Assemelha-se à Ctenitis deflexa (Kaulf.) Copel., que possui cílios em toda a extensão da margem (Christensen, 1913). Espécie terrícola, crescendo nas trilhas e no interior da floresta, em locais úmidos e sombreados.

Material selecionado examinado: Mazziero \& Soller 571 (UPCB, SP, UNIP, NY); Mazziero 1000 (UPCB, RB, MBM); Mazziero 1025 (UPCB, SP, UNIP, NY, CAS).

9.2. Ctenitis aspidioides (C. Presl) Copel., Gen. Fil. (Copeland) 124. 1947.

Ctenitis laetevirens (Rosenst.) Salino \& P.O. Morais é semelhante à esta espécie, mas difere por apresentar segmentos desprovidos de tricomas catenados nas margens e lâmina com ápice pinatífido, enquanto que, em C. aspidioides, o ápice da lâmina é conforme e há tricomas catenados na margem dos segmentos (Salino \& Morais, 2003). Espécie terrícola, encontrada nas trilhas e interior da floresta, em locais úmidos e sombreados.

Material selecionado examinado: Mazziero \& Soller 594 (UPCB, UNIP); Mazziero \& Soller 595 (UPCB); Mazziero \& Soller 596 (UPCB, NY, CAS); Mazziero \& Soller 687 (UPCB, SP); Mazziero et al. 959 (UPCB, RB).

9.3. Ctenitis distans (Brack.) Ching, Bull. Fan Mem. Inst. Biol. Bot. 8: 277. 1938.

Segundo Christensen (1913), C. falciculata é a espécie que mais se assemelha à $C$. distans, separando-se por apresentar 5-10 pares de nervuras por segmento e escamas costais ovais, por sua vez, C. distans apresenta 12-15 pares de nervuras por segmento e escamas linear-lanceoladas. Espécie terrícola ou rupícola sobre afloramentos de calcário, encontrada no interior da floresta ou nas trilhas, em locais sombreados ou exposta ao sol.

Material selecionado examinado: Mazziero \& Soller 561 (UPCB, UNIP, NY); Mazziero \& Soller 673 (UPCB, SP); Mazziero \& Soller 674 (UPCB, CAS); Mazziero \& Soller 822 (UPCB, RB); Mazziero et al. 975 (UPCB).
9.4. Ctenitis falciculata (Raddi) Ching, Sunyatsenia 5(4): 250. 1940.

Espécie semelhante à C. pedicellata, mas difere por apresentar um único par de nervuras atingindo o sinus e pela presença de indúsio, enquanto, em $C$. pedicellata, 4-5 pares de nervuras atingem o sinus e o indúsio é ausente (Christensen, 1913). Espécie terrícola, encontrada no interior da floresta, em locais sombreados e úmidos.

Material selecionado examinado: Mazziero et al.935 (UPCB, SP, UNIP, NY); Mazziero 1021 (UPCB, SP, CAS).

9.5. Ctenitis pedicellata (H. Christ.) Copel., Gen. Fil. 124. 1947.

Espécie semelhante à C. falciculata. A distinção entre elas é apresentada nos comentários acerca da mesma (item 9.4). Espécie terrícola, habitando às margens dos córregos no interior da floresta, em locais sombreados.

Material selecionado examinado: Mazziero \& Soller 854 (UPCB, SP, UNIP); Mazziero et al.944 (UPCB, NY, CAS); Mazziero 1022 (UPCB, RB); Mazziero 1029 (UPCB).

9.6. Ctenitis submarginalis (Langsd. \& Fisch.) Ching, Sunyatsenia 5: 240. 1940.

Dentre as espécies glabras ou com tricomas catenados, baciliformes ou glandulares, no tecido laminar (e.g., Ctenitis christensenii R.S. Viveros \& Salino, C. falciculata, Ctenitis glandulosa R.S. Viveros e Ctenitis paranaensis (C. Chr.) Lellinger), difere pelo apículo no ápice dos segmentos (Viveros \& Salino, 2017). Espécie terrícola, encontrada no interior da floresta, em locais sombreados e úmidos.

Material selecionado examinado: Mazziero \& Soller 667 (UPCB, SP); Mazziero 1023 (UPCB, SP, UNIP).

9.7. Elaphoglossum glabellum J. Sm., London J. Bot. 1: 197. 1842.

Espécie com a lâmina alcançando até $1,5 \mathrm{~cm}$ de largura, de consistência coriácea e nervuras com ápice não espessado, atingindo a margem da lâmina, por sua vez, em Elaphoglossum brachyneuron (Fée) J.Sm., a lâmina tem consistência membranácea, até $1 \mathrm{~cm}$ de largura, o ápice das nervuras é espesso e não atinge a margem da lâmina (Alston, 1958). Espécie epífita, crescendo em locais sombreados e úmidos, nas trilhas. 
Material selecionado examinado: Mazziero \& Engels 1171 (UPCB, SP).

9.8. Elaphoglossum glaziovii (Fée) Brade, Sellowia 18: 99. 1966.

Elaphoglossum amorimii F.B. Matos \& Mickel e E. prestonii são semelhantes à E. glaziovii, no entanto, apresentam escamas marrom-escuras a negras no pecíolo e na costa, as quais são estramíneas ou marrom-claras, em E. glaziovii (Matos \& Mickel, 2014). Espécie rupícola, observada nas trilhas, em locais sombreados e úmidos.

Material selecionado examinado: Mazziero \& Soller 865 (UPCB, SP, UNIP); Mazziero \& Soller 901 (UPCB); Mazziero \& Soller 923 (UPCB); Mazziero 1067 (UPCB, NY); Mazziero \& Albiero Jr. 1113 (UPCB).

9.9. Elaphoglossum iguapense Brade, Arq. Inst. Biol. Veg. 3: 6. 1936.

Separa-se de Elaphoglossum actinotricum (Mart.) T. Moore e Elaphoglossum tectum (Humb. \& Bonpl. ex Willd.) T. Moore pela lâmina com 4,5 $\mathrm{cm}$ de largura e base decurrente; as duas espécies aqui mencionadas apresentam lâmina com a base cuneada e até 1,5-2 cm de largura (Alston, 1958). Espécie rupícola, crescendo às margens de riachos, em locais sombreados e úmidos.

Material selecionado examinado: Mazziero \& Soller 836 (UPCB, SP); Mazziero \& Soller 898 (UPCB); Mazziero 1065 (UPCB, UNIP).

9.10. Elaphoglossum lingua (C. Presl) Brack., U. S. Expl. Exped. Filic. 16: 74. 1854.

Elaphoglossum lingua se assemelha à E. vagans e Elaphoglossum paulistanum Rosenst., no entanto, estas duas espécies apresentam ápice das frondes estéreis acuminado, enquanto, em $E$. lingua, o ápice é obtuso (Alston, 1958). Espécie epífita ou rupícola, em locais sombreados e úmidos, nas trilhas e no interior da floresta.

Material selecionado examinado: Mazziero \& Soller 625 (UPCB, NY, CAS); Mazziero \& Soller 885 (UPCB, SP, UNIP).

9.11. Elaphoglossum Iuridum (Fée) Christ, Neue. Denkschr. Allg. Schweiz. Ges. Gesammten Naturwiss 36(1): 33. 1899.

Em Elaphoglossum crassinerve (Kunze) T. Moore, a lâmina estéril é glabra em ambas às faces e, em E. luridum, a costa abaxial, principalmente do terço inferior, apresenta escamas nigrescentes, com margem denteado-uncinadas (Brade, 1961). Espécie epífita, encontrada em locais sombreados, no interior da floresta.

Material selecionado examinado: Mazziero et al. 985 (UPCB, SP, UNIP, NY).
9.12. Elaphoglossum macrorhizum (Baker) C. Chr., Index Filic. 310. 1905.

De acordo com Alston (1958), esta espécie apresenta frondes com até $60 \mathrm{~cm}$ de comprimento, o que a separa de Elaphoglossum blanchetii (Mett.) C. Chr. e Elaphoglossum rigidum Urb., nas quais o comprimento da fronde não ultrapassa $35 \mathrm{~cm}$. Espécie epífita, crescendo no interior da floresta, em locais sombreados e úmidos.

Material selecionado examinado: Mazziero 1044 (UPCB); Mazziero \& Albiero Jr. 1121 (UPCB, SP, UNIP, NY).

9.13. Elaphoglossum nigrescens (Hook.) T. Moore ex Diels, Nat. Pflanzenfam. 1(4): 332. 1899.

De acordo com Vasco et al. (2009), que revisaram o grupo de Elaphoglossum ciliatum (C. Presl) T. Moore, esta espécie apresenta a lâmina afunilando-se até alcançar o filopódio e pelas escamas dissectas na margem da lâmina. Estas características estão ausentes em Elaphoglossum burchellii (Baker) C. Chr. e Elaphoglossum huacsaro (Ruiz) H. Christ, as demais espécies do grupo que ocorrem no Brasil (Vasco et al., 2009). Espécie epífita, encontrada no interior da floresta, em locais úmidos e sombreados.

Material selecionado examinado: Mazziero \& Soller 924 (UPCB, SP).

9.14. Elaphoglossum prestonii (Baker) J. Sm., Ferns Brit. For. (Ed. 2) 298. 1877.

Separa-se de E. amorimii por apresentar escamas da margem da lâmina de coloração marrom a castanha, pela lâmina coloração verde escura (em material herborizado) e pelo hábito rupícola ou terrícola, raro epífita (vs. escamas estramíneas, lâmina verde-amarelada em material herborizado e habito exclusivamente epífita, em E. amorimii) (Matos \& Mickel, 2014). Espécie rupícola, crescendo em locais sombreados e úmidos, nas trilhas.

Material selecionado examinado: Mazziero \& Soller 897 (UPCB, SP).

9.15. Elaphoglossum strictum (Raddi) T. Moore, Index Filic., 158. 1857.

Espécie reconhecida pela mistura de escamas castanho-claras e escuras na costa, frondes estéreis com até $2 \mathrm{~cm}$ de largura e escamas lanceoladas com margem ciliadas encontrada no tecido laminar adaxial (Alston, 1958; Brade, 1961). Espécie epífita, habitando locais sombreados e úmidos, no interior da floresta.

Material selecionado examinado: Mazziero \& Engels 1159 (UPCB, SP).

9.16. Elaphoglossum vagans (Mett.) Hieron., Bot. Jahrb. Syst. 34: 543. 1904. 
Semelhante à $E$. paulistanum, porém, com lâmina estéril cerca de 3 vezes mais longa do que larga e de mesmo comprimento que a fértil (vs. lâmina cerca de 6 vezes mais longa que larga e maior que a fértil, em E. paulistanum) (Alston, 1958). Espécie terrícola, observada em locais sombreados e úmidos, no interior da floresta.

Material selecionado examinado: Mazziero \& Albiero Jr. 1099 (UPCB, NY); Mazziero \& Albiero Jr. 1134 (UPCB, SP, UNIP).

9.17. Lastreopsis amplissima (C. Presl) Tindale, Vict. Nat. 73: 185. 1957.

Segundo Prado \& Hirai (2010a), Parapolystichum acutum (Hook.) Labiak, Sundue \& R. C. Moran diferencia-se por apresentar gema prolífera e lâmina catádroma (vs. gema ausente e lâmina anádroma, em L. amplissima). Espécie terrícola, encontrada em locais sombreados e úmidos, no interior da floresta, trilhas ou margens de estradas.

Material selecionado examinado: Mazziero \& Soller 693 (UPCB); Mazziero 1038 (UPCB, UNIP, CAS); Mazziero 1039 (UPCB, SP, NY).

9.18. Megalastrum albidum R. C. Moran, J. Prado \& Labiak, Amer. Fern J. 99(1): 1-44. 2009.

Semelhante à Megalastrum canescens (Kunze ex Mett.) A. R. Sm. \& R. C. Moran, mas esta apresenta pinas basais 2-pinado-pinatífidas e as medianas 2-pinado-pinatissectas, com tricomas glandulares, enquanto, M. albidum possui lâmina 3-pinado-pinatissecta (pinas basais) e 2-pinado-pinatífida (pinas medianas), desprovida de tricomas glandulares (Moran et al., 2009). Espécie terrícola, encontrada em locais sombreados e úmidos, na borda da floresta.

Material selecionado examinado: Mazziero et al. 956 (UPCB, SP).

9.19. Megalastrum connexum (Kaulf.) A. R. Sm. \& R. C. Moran, Amer. Fern J. 77: 128. 1987.

De acordo com Moran et al. (2009), é uma espécie semelhante à Megalastrum brevipubens R. C. Moran, J. Prado \& Labiak, mas esta última apresenta tricomas com cerca de $0,1 \mathrm{~mm}$ de comprimento no tecido laminar, sendo este glabro em M. connexum. Espécie terrícola, ocorrendo em locais sombreados e úmidos.

Material selecionado examinado: Mazziero \& Soller 554 (UPCB); Mazziero \& Soller 555 (UPCB, UNIP); Mazziero \& Soller 557 (UPCB, UNIP); Mazziero \& Soller 668 (UPCB, CAS); Mazziero et al. 934 (UPCB, SP).

9.20. Megalastrum umbrinum (C. Chr.) A. R. Sm. \& R. C. Moran, Amer. Fern J. 77: 129. 1987.

A espécie mais semelhante é Megalastrum adenopteris (C. Chr.) A. R. Sm. \& R. C. Moran, mas esta apresenta indúsio caduco e tecido laminar adaxial uniformemente pubescente, enquanto $M$. umbrinum não apresenta indúsio e o tecido laminar adaxial é glabro (ou com tricomas esparsos próximos a margem) (Moran et al., 2009). Espécie terrícola, encontrada nas margens de córregos e trilhas, em locais sombreados.

Material selecionado examinado: Mazziero \& Soller 672 (UPCB); Mazziero \& Soller 916 (UPCB, UNIP, CAS); Mazziero et al. 940 (UPCB, SP, NY).

9.21. Mickelia scandens (Raddi) R. C. Moran, Labiak \& Sundue, Brittonia 62(4): 354. 2010.

Mickelia pradoi R. C. Moran, Labiak \& Sundue é uma espécie semelhante, mas apresenta rizoma nigrescente, lâmina com ápice abruptamente reduzido e de $9-13$ pares de pinas, enquanto, $M$. scandens apresenta coloração do rizoma marrom a marrom-avermelhado, lâmina com ápice gradualmente reduzido e 22-25 pares de pinas (Moran et al. 2010). Espécie hemiepífita, terrícola ou rupícola, encontrada em locais sombreados e úmidos, no interior da floresta e às margens de córregos.

Material selecionado examinado: Mazziero \& Soller 643 (UPCB, CAS); Mazziero et al. 943 (UPCB, SP, UNIP, NY).

9.22. Olfersia cervina (L.) Kunze, Flora 7: 312. 1824.

Única espécie do gênero no Brasil, reconhecida das espécies de Dryopteridaceae encontradas no Estado de São Paulo, pelas características apresentadas nas chaves. Espécie rupícola, crescendo junto às margens de córregos e rios, em locais sombreados.

Material selecionado examinado: Mazziero \& Soller 845 (UPCB, SP, UNIP).

9.23. Parapolystichum effusum (Sw.) Ching, Sunyatsenia 5(4): 239. 1940.

Separa-se de Lastreopsis amplissima, por apresentar lâmina catádroma e gemas nas pinas distais (Prado e Hirai, 2010a). Espécie terrícola, encontrada em locais sombreados e úmidos, no interior da floresta e às margens de pequenos riachos.

Material selecionado examinado: Mazziero \& Soller 844 (UPCB, NY, CAS); Mazziero et al.939 (UPCB, SP, UNIP).

9.24. Polybotrya cylindrica Kaulf., Enum. Fil. 56. 1824.

Segundo Moran (1987), P. cylindrica separa-se das demais espécies brasileiras, pelas escamas marrons, opacas, com a base espessada e curvada, além da presença de tricomas articulados $(<0,1 \mathrm{~mm})$ na margem dos segmentos. Espécie hemiepífita, observada em trilhas ou no 
interior da floresta, em locais úmidos e sombreados.

Material selecionado examinado: Mazziero \& Soller 579 (UPCB, UNIP, NY); Mazziero \& Soller 647 (UPCB, SP); Mazziero 1020 (UPCB).

9.25. Rumohra adiantiformis (G. Forst.) Ching, Sinesia 5: 70. 1934.

Difere das outras duas espécies do gênero encontradas no Brasil, por apresentar lâmina mais ampla na porção mediana, pinas basais 3-pinado- pinatífidas, escamas da base do pecíolo ciliadas, com cílios maiores que $0,5 \mathrm{~mm}$, e tricomas glandulares ausentes ou, se presentes, apenas de um tipo (vs. dois tipos de tricomas glandulares, sempre presentes em Rumohra glandulosissima Sundue \& J. Prado e lâmina mais ampla na base, pinas basais 2-pinado-pinatífidas e escamas fracamente denteadas em Rumohra quadrangularis (Fée) Brade) (Sundue et al., 2013). Espécie terrícola, rupícola ou epífita, crescendo em locais expostos ao sol e úmidos.

Material selecionado examinado: Mazziero \& Soller 703 (UPCB).

9.26. Stigmatopteris brevinervis (Fée) R. C. Moran, Ann. Missouri Bot. Gard., 78(4): 871. 1991.

Espécie semelhante à Stigmatopteris tyucana (Raddi) C. Chr., no entanto, em S. brevinervis as incisões das pinas atingem $1 / 2$ até $2 / 3$ da distância entre a costa e a margem (vs. incisões das pinas atingindo $1 / 3$ até $1 / 2$ da distância entre a costa e a margem, em S. tyucana) (Moran, 1991). Espécie terrícola, encontrada no interior da floresta, em locais úmidos e sombreados.

Material selecionado examinado: Mazziero et al.984 (UPCB, SP, UNIP).

9.27. Stigmatopteris caudata (Raddi) C. Chr., Bot. Tidsskr. 29: 302. 1909.
Segundo Moran (1991), esta espécie se assemelha à Stigmatopteris ichthiosma (Sodiro) C. Chr. que apresenta indúsio escamiforme, os quais são ausentes em S. caudata. Espécie terrícola, crescendo próximo aos córregos, em locais ensolarados e úmidos.

Material selecionado examinado: Mazziero et al. 973 (UPCB, SP, UNIP, NY).

9.28. Stigmatopteris heterocarpa (Fée) Rosenst., Repert. Spec. Nov. Regni Veg. 21: 347. 1925.

De acordo com Moran (1991), a melhor característica para distinguir esta espécie de Stigmatopteris tyucana (Raddi) C. Chr. é o grau de incisão das pinas, sendo que em $S$. heterocarpa a margem das pinas pode ser serreada, crenada ou com incisões atingindo, no máximo, 1/4 da distância da costa e a margem, enquanto em $S$. tyucana a pina é sempre incisa e as incisões alcançam 1/3-1/2 da distância entre a margem e a costa. Espécie terrícola, observada em locais úmidos e sombreados, nas trilhas e no interior da floresta.

Material selecionado examinado: Mazziero et al.947 (UPCB, SP, UNIP); Mazziero et al.969 (UPCB, NY, CAS).

\section{EQUISETACEAE}

10.1. Equisetum giganteum L., Syst. Nat. (10. Ed.) 2: 1318. 1759 .

Única espécie do gênero no Brasil (Nóbrega \& Prado, 2017), sendo prontamente reconhecida pelas características apresentadas na chave. Espécie terrícola (Nóbrega \& Prado, 2017) que ocorre, preferencialmente, em locais alagados e abertos (Tryon \& Stolze, 1994).

Material selecionado examinado: BRASIL. São Paulo, Mun. Apiaí, 1.IV.1882, A. Lofgren S.n. (P).

\section{GLEICHENIACEAE}

1. Gemas protegidas por escamas; nervuras uma vez furcadas.

2. Aflébias ausentes; nervuras e tecido laminar densamente revestidos por escamas aracnoides al-

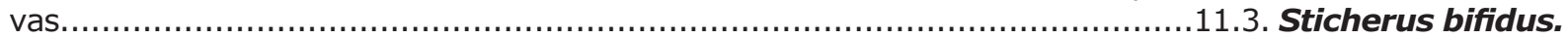

2 '. Aflébias presentes; nervuras e tecido laminar glabros ou com escamas esparsas.

3. Costa com escamas patentes, marrom-escuras a negras...................11.4. Sticherus nigropaleaceus.

$3^{\prime}$. Costa com escamas adpressas, hialino-alaranjadas...........................11.5. Sticherus squamosus.

$1^{\prime}$. Gemas protegidas por tricomas; nervuras 2-4 vezes furcadas.

4. Pinas acessórias presentes nas bifurcações.

$4^{\prime}$. Pinas acessórias ausentes.

11.1. Dicranopteris flexuosa.

11.1. Dicranopteris flexuosa (Schrad.) Underw., Bull. Torrey Bot. Club 34: 254. 1907.

Dicranopteris linearis (Burm. f.) Underw. apresenta face abaxial com nervuras proeminentes e segmentos lineares, com ápice agudo e margem fortemente revoluta (vs. nervuras proeminentes em ambas as faces com as nervuras proeminentes e segmentos elípticos com ápice arredondado e margem nada ou pouco revoluta, em D. flexuosa) (Prado \& Labiak, 2003). Espécie 
rupícola ou terrícola, crescendo em locais abertos, exposta ao sol.

Material selecionado examinado: Mazziero \& Soller 694 (UPCB, SP, UNIP).

11.2. Gleichenella pectinata (Willd.) Ching, Sunyatsenia 5: 276. 1940.

Pertencente a um gênero monotípico e tem em $D$. flexuosa a espécie brasileira de Gleicheniaceae mais semelhante e da qual se diferencia facilmente, por não apresentar pinas acessórias nas bifurcações. Espécie terrícola, que cresce em barrancos nas estradas, em locais abertos, exposta ao sol.

Material selecionado examinado: Mazziero \& Soller 650 (UPCB, SP, UNIP, NY).

11.3. Sticherus bifidus (Willd.) Ching, Sunyatsenia 5: 282. 1940.

Gonzales \& Kessler (2011) separam esta espécie das demais do gênero, principalmente, por não apresentar aflébias, pelos ramos terminais sem os segmentos proximais internos, pelas nervuras secundárias pouco proeminentes na face abaxial e pelas escamas da gema lanceoladas e ciliadas. Espécie terrícola, observada em barrancos nas estradas, trilhas ou borda da floresta, em locais abertos e ensolarados.

Material selecionado examinado: Mazziero \& Soller 819 (UPCB, SP, UNIP); Mazziero 993 (UPCB, NY, CAS); Mazziero 994 (UPCB).

11.4. Sticherus nigropaleaceus (J.W. Sturm) J. Prado \& Lellinger, Amer. Fern J. 86(3): 98-101, f. 1 A-B. 1996.

A espécie mais semelhante à $S$. nigropaleaceus é Sticherus interjectus (Jeremy \& T. Walker) J. Gonzales, no entanto, na primeira, as escamas da gema ficam escurecidas do ápice em direção à base, enquanto na segunda, o escurecimento começa a partir da base em direção ao ápice (Gonzales \& Kessler, 2011). Espécie terrícola, encontrada crescendo em barrancos nas estradas e trilhas, a pleno sol e junto à Gleichenella pectinata e Sticherus bifidus.

Material selecionado examinado: Mazziero \& Soller 651 (UPCB, SP, UNIP); Mazziero \& Soller 820 (UPCB).

11.5. Sticherus squamosus (Fée) J. Gonzales, Phytotaxa 31: 47. 2011.

Esta espécie pode ser reconhecida por apresentar escamas costais alaranjado-escuras a castanho-escuras, além de apresentar ramos proximais curtos, que se distanciam em ângulo aproximado de $90^{\circ}$, com dois segmentos por centímetro (Gonzales \& Kessler, 2011). Espécie terrícola, observada em barrancos, sombreados e úmidos, na beira das estradas, junto à Sticherus bifidus.

Material selecionado examinado: Mazziero 1035 (UPCB, SP, UNIP).

\section{HEMIDICTYACEAE}

12.1. Hemidictyum marginatum (L.) C. Presl, Tent. Pterid. 111, t. 3, f. 24. 1836.

Trata-se da única espécie do gênero (PPG I, 2016) e, devido aos soros lineares, pode ser confundida, principalmente, com espécies do gênero Asplenium e Diplazium, porém, H. marginatum pode ser facilmente reconhecida pelas características evidenciadas na chave. Espécie terrícola, encontrada no interior da floresta, próxima aos córregos, em locais sombreados.

Material selecionado examinado: Mazziero 1050 (UPCB).

\section{HYMENOPHYLLACEAE}

1. Invólucros bivalves.

2. Lâmina glabra.

3. Pecíolo não alado

13.5. Hymenophyllum asplenioides.

3'. Pecíolo alado.

4. Frondes com 12-20 cm de comprimento; lâmina deltoide a oval-deltoide; algumas pinas com ápice alongado. 13.6. Hymenophyllum caudiculatum.

4'. Frondes menores que $12 \mathrm{~cm}$ de comprimento; lâmina oblongo-lanceolada; pinas sem ápice alongado .13.11. Hymenophyllum polyanthos.

2'. Lâmina pilosa.

5. Raque não alada, ou alada somente a partir do segundo par de pinas.

6. Lâmina com crescimento indeterminado; lâmina com predomínio de tricomas estrelados na margem.

13.12. Hymenophyllum pulchellum.

6'. Lâmina com crescimento determinado; lâmina com predomínio de tricomas simples e/ou furcados na margem.

7. Pinas basais pecioluladas.

13.9. Hymenophyllum lineare.

7'. Pinas basais sésseis

13.7. Hymenophyllum elegans.

$5^{\prime}$. Raque inteiramente alada.

8. Caule espesso (>0,5 mm de diâmetro); pecíolo não alado ou alado apenas próximo à lâmina. .13.10. Hymenophyllum microcarpum. 
8'. Caule delgado (< 0,3 mm de diâmetro); pecíolo alado em toda sua extensão.......

$1^{\prime}$. Invólucros cônicos, bilabiados.

9. Tecido laminar com falsas nervuras, frequentemente paralelas às nervuras verdadeiras.

10. Invólucros presentes nos segmentos laterais e apicais, completamente imersos no tecido laminar. 13.3. Didymoglossum krausii.

10'. Invólucros presentes apenas nos segmentos apicais, somente com a porção basal imersa no tecido laminar.

13.4. Didymoglossum hymenoides.

9'. Tecido laminar sem falsas nervuras.

11. Caule ereto.

12. Raque cilíndrica, às vezes levemente alada próximo ao ápice; pinas proximais pediceladas......

13.1. Abrodictyum rigidum.

$12^{\prime}$. Raque quadrangular, amplamente alada próximo ao ápice; pinas adnatas;

$11^{\prime}$. Caule curto a longo-reptante.

13.18. Trichomanes elegans.

13. Margem da lâmina com tricomas.

14. Caule curto-reptante; lâmina pinatissecta a 1-pinada.

15. Pecíolo alado, desde a porção mediana até a distal

15'. Pecíolo não alado.

16. Frondes arqueadas, deltoides a largo-lanceoladas.

13.19. Trichomanes pellucens.

$16^{\prime}$. Frondes eretas, lineares a linear-lanceoladas.

14'. Caule longo-reptante; lâmina pinatífida.

17. Lâmina com venação anádroma; soros surgindo predominantemente na axila acroscópica dos segmentos.... 13.16. Trichomanes anadromum.

17'. Lâmina com venação catádroma; soros surgindo predominantemente no ápice dos segmentos. 13.21. Trichomanes polypodioides.

13'. Margem da lâmina glabra.

18. Plantas epífitas ou rupícolas; caule delgado $(<0,8 \mathrm{~mm}$ de diâmetro) com raízes ausentes ou escassas e delicadas.

19. Raque não alada.

19'. Raque alada.

20. Caule coberto por tricomas negros; tecido laminar dos segmentos distais revoluto, formando sulcos paralelos à nervura principal....

20 '. Caule coberto por tricomas castanhos; tecido laminar plano.

21. Pecíolo inteiramente alado; ala da raque fortemente ondulada e mais larga que a própria raque......

13.14. Polyphlebium diaphanum.

$21^{\prime}$. Pecíolo alado apenas próximo às pinas, geralmente, $1 / 2$ - $1 / 3$ distais; ala da raque plana a levemente ondulada, de mesma largura ou mais estreita do que a raque........................................................13.15. Polyphlebium hymenophylloides.

18'. Plantas hemiepífitas; caule espesso ( $>1 \mathrm{~mm}$ de diâmetro), sempre com raízes numerosas e robustas.

22. Caule com tricomas esparsos; lâmina 1-pinado-pinatífida na porção mediana........................................................................13.23. Vandenboschia rupestris.

22 '. Caule densamente coberto por tricomas; lâmina 2-pinado-pinatífida ou mais complexa na porção mediana.

13.22. Vandenboschia radicans.

13.1. Abrodictyum rigidum (Sw.) Ebihara \& Dubuisson, Blumea 51(2): 23. 2006.

Abrodictyum rigidum pode ser separada de Trichomanes elegans Rich. (espécie com a qual mais se assemelha no PETAR), pelo pecíolo não alado, raque cilíndrica, pinas pecioladas e costa não alada (vs. pecíolo alado, ao menos, na porção distal, raque quadrangular, pinas adnatas e costa alada, em T. elegans) (Pacheco, 1995; Tryon \& Stolze, 1989a). Espécie terrícola, encontrada no interior da floresta, em locais sombreados.

Material selecionado examinado: Mazziero et al. 983 (UPCB, SP); Mazziero \& Albiero Jr.
1087 (UPCB, UNIP); Mazziero \& Albiero Jr. 1120 (UPCB).

13.2. Crepidomanes pyxidiferum (L.) Dubuisson \& Ebihara, Acta Bot. Gallica Bot. Lett. 160(2): 186. 2013.

Única espécie do gênero no Brasil (Windisch, 2015), pode ser reconhecida por apresentar caule com tricomas negros e tecido laminar, dos segmentos terminais, revoluto e formando sulcos (Mickel \& Smith, 2004; Tryon \& Stolze, 1989a). Espécie rupícola ou epífita, observada no interior da floresta em locais sombreados e úmidos. 
Material selecionado examinado: Mazziero \& Soller 572 (UPCB); Mazziero \& Soller 896 (UPCB); Mazziero \& Soller 900 (UPCB); Mazziero 1033 (UPCB, SP); Mazziero \& Albiero Jr. 1125 (UPCB, SP, UNIP, RB, NY, CAS).

13.3. Didymoglossum krausii (Hook. \& Grev.) C. Presl, Hymenophyllaceae 115. 1843.

Segundo Boer (1962), esta espécie pode ser confundida com Didymoglossum reptans (Sw.) C. Presl que apresenta invólucros não imersos no tecido laminar e muitas falsas vênulas presentes no tecido laminar, mas poucas destas paralelas às nervuras verdadeiras (vs. invólucros parcialmente ou completamente imersos no tecido laminar e falsas vênulas, em sua maioria, paralelas às nervuras verdadeiras, em $D$. krausii). Espécie rupícola, crescendo sobre rochas às margens dos córregos, a pleno sol e em locais sombreados.

Material selecionado examinado: Mazziero \& Soller 583 (UPCB, NY, CAS); Mazziero \& Soller 895 (UPCB); Mazziero \& Soller 905 (UPCB, SP); Mazziero \& Soller 908 (UPCB, SP, UNIP, NY); Mazziero 1059 (UPCB).

13.4. Didymoglossum hymenoides (Hedw.) Copel., Phillp. J. Sci. 67: 77. 1938.

Assemelha-se à $D$. krausii, sendo prontamente diferenciada pelos caracteres indicados na chave. Espécie epífita ou rupícola em ambientes florestais sombreados e úmidos (Windisch, 2014; 2015).

Material selecionado examinado: BRASIL. São Paulo, Mun. Apiaí, s.d., J. J. Puiggari 2405 (P).

13.5. Hymenophyllum asplenioides (Sw.) Sw., J. Bot. (Schrader) 1800(2): 98. 1801(1802).

De acordo com Hirai \& Prado (2011), esta espécie pode ser caracterizada pela presença de pecíolo alado e glabro. Espécie epífita, observada no interior da floresta, em locais sombreados e úmidos.

Material selecionado examinado: Mazziero \& Albiero Jr. 1119 (UPCB).

13.6. Hymenophyllum caudiculatum Mart., Icon. PI. Crypt. 102, t. 67. 1834.

Difere de Hymenophyllum microcarpum e $\mathrm{H}$. polyanthos, por apresentar quase todas as pinas com ápice caudado e lâmina glabra (Hirai \& Prado, 2011). Espécie epífita, encontrada no interior da floresta, em locais sombreados e úmidos.

Material selecionado examinado: Mazziero 1026 (UPCB, SP, UNIP, NY, CAS).

13.7. Hymenophyllum elegans Spreng., Syst. Veg. 4: 133. 1827.
Segundo Morton (1947), diferencia-se das demais espécies do gênero, que possuem tricomas junto às nervuras e nas margens dos segmentos, por apresentar tricomas do pecíolo simples ou furcados, tricomas marginais furcados na base (sendo a maioria duas vezes furcados) e pinas com 4,5-8 $\mathrm{mm}$ de comprimento com 1-2 pares de segmentos. Espécie rupícola, crescendo às margens dos córregos a pleno sol.

Material selecionado examinado: Mazziero \& Soller 987 (UPCB).

13.8. Hymenophyllum hirsutum (L.) Sw., J. Bot. (Schrader) 1800(2): 99. 1801.

Esta espécie caracteriza-se pelo pecíolo alado na metade superior e tricomas estrelados no pecíolo, raque, nervuras, margem do indúsio e nas duas faces do tecido laminar (Hirai \& Prado, 2011). Espécie rupícola ou epífita, em locais sombreados, às margens de córregos e no interior da floresta.

Material selecionado examinado: Mazziero \& Soller 669 (UPCB, SP, UNIP, NY); Mazziero \& Soller 886 (UPCB); Mazziero \& Soller 911 (UPCB); Mazziero \& Albiero Jr. 1080 (UPCB).

13.9. Hymenophyllum lineare (Sw.) Sw., J. Bot. (Schrader) 1800(2): 100. 1801.

Dentre as demais que possuem tricomas exclusivamente nas margens dos segmentos e sobre as nervuras, esta espécie pode ser reconhecida por apresentar frondes de crescimento determinado, ovais a oblongas, com tricomas simples ou furcados na base, restrito às margens dos segmentos (Morton, 1947). Espécie epífita ou rupícola (Windisch, 2015), não encontrada recentemente na área de estudo, no entanto, dados da literatura indicam sua ocorrência em locais sombreados no interior da floresta (Stolze, 1976).

Material selecionado examinado: BRASIL. São Paulo, Mun. Apiaí, s.d., J. J. Puiggari s.n. (RB).

13.10. Hymenophyllum microcarpum Desv., Mém. Soc. Linn. Paris 6: 333. 1827.

Segundo Tryon \& Stolze (1989a), Hymenophyllum valvatum Hook. \& Grev., é uma semelhante à $H$. microcarpum, porém, a primeira apresenta segmentos terminais e ala da raque leve a fortemente ondulados e ausência de tricomas estrelados no pecíolo, enquanto, em $H$. microcarpum, os segmentos terminais e a ala da raque são pouco ou nada ondulados e apresenta tricomas estrelados no pecíolo. Espécie rupícola, crescendo às margens de cursos d'água, em locais expostos ao sol.

Material selecionado examinado: Mazziero \& Soller 891 (UPCB, SP, UNIP, NY).

13.11. Hymenophyllum polyanthos (Sw.) Sw., J. Bot. (Schrader) 1800 (2): 102. 1801. 
De acordo com Tryon \& Stolze (1989a), esta espécie é semelhante à Hymenophyllum myriocarpum Hook., contudo, esta espécie apresenta invólucro, geralmente, subgloboso e os segmentos basais das pinas sobrepondo à raque, enquanto, em $H$. polyanthos, os invólucros são ovais e os segmentos são afastados da raque, podendo, algumas vezes, toca-la. Espécie epífita, observada no interior da floresta, em locais sombreados e úmidos.

Material selecionado examinado: Mazziero et al. 964 (UPCB); Mazziero 1027 (UPCB, SP); Mazziero 1056 (UPCB, UNIP).

13.12. Hymenophyllum pulchellum Schltdl. \& Cham., Linnaea 5: 618. 1830.

Espécie semelhante à Hymenophyllum rufum Fée, porém, apenas as nervuras e margem dos segmentos apresentam tricomas (em $H$. rufum, ocorrem tricomas em todo tecido laminar) (Schwartsburd \& Labiak, 2007). Espécie epífita, encontrada no interior da floresta, em locais sombreados e úmidos.

Material selecionado examinado: Mazziero \& Engels 1163 (UPCB).

13.13. Polyphlebium angustatum (Carmich.) Ebihara \& Dubuisson, Blumea 51(2): 20. 2006.

Segundo Mickel \& Smith (2004), P. angustatum é relacionada com Polyphlebium capillaceum (L.) Ebihara \& Dubuisson, integrando um complexo de espécies. De acordo com esses autores, tais espécies podem ser distinguidas por $P$. angustatum apresentar segmentos terminais com $0,5-0,7 \mathrm{~mm}$ de largura e costa alada até a raque (vs. segmentos com 0,1-0,4 mm e costa não alada, em $P$. capillaceum). Espécie epífita, crescendo sobre Cyatheaceae, em locais sombreados e úmidos do interior da floresta ou margens de córregos.

Material selecionado examinado: Mazziero \& Soller 575 (UPCB); Mazziero \& Soller 605 (UPCB, CAS); Mazziero \& Soller 658 (UPCB, UNIP); Mazziero et al.970 (UPCB, SP, NY).

13.14. Polyphlebium diaphanum (Kunth) Ebihara \& Dubuisson, Blumea 51(2): 20. 2006.

Polyphlebium hymenophylloides (Bosch) Ebihara \& Dubuisson é uma espécie semelhante à $P$. diaphanum, sendo as características propostas na chave as que melhor as diferenciam. Espécie epífita, observada no interior da floresta, em pontos sombreados e úmidos.

Material selecionado examinado: Mazziero \& Soller 609 (UPCB); Mazziero \& Soller 925 (UPCB).

13.15. Polyphlebium hymenophylloides (Bosch) Ebihara \& Dubuisson, Blumea 51(2): 20. 2006.
Polyphlebium hymenophylloides é semelhante à $P$. diaphanum e as diferenças entre elas são tratadas na chave. Espécie epífita, encontrada em ambientes úmidos e sombreados no interior da floresta.

Material selecionado examinado: Mazziero \& Soller 904 (UPCB, SP).

13.16. Trichomanes anadromum Rosenst., Repert. Spec. Nov. Regni Veg. 21(21-25): 344. 1925.

Esta espécie é semelhante à T. polypodioides, porém, $T$. anadromum apresenta invólucros axilares solitários e venação anádroma, enquanto que, em T. polypodioides, 2-4 invólucros estão presentes no ápice dos segmentos e a venação é catádroma (Pacheco, 1995; Windisch, 2014). Espécie epífita, observada sobre Cyatheaceae no interior da floresta, em locais sombreados e úmidos.

Material selecionado examinado: Mazziero \& Albiero Jr. 1086 (UPCB).

13.17. Trichomanes cristatum Kaulf., Enum. Filic. 265. 1824.

Assemelha-se à $T$. pilosum, a qual, apresenta frondes arqueadas, com 3-25 cm de comprimento, deltoides ou largo-lanceoladas (vs. frondes eretas e maiores, com $15-54 \mathrm{~cm}$ de comprimento, lineares a linear-lanceoladas, em T. cristatum) (Windisch, 1992b). Espécie terrícola, crescendo em local sombreado e solo seco, no interior da floresta.

Material selecionado examinado: Mazziero et al. 951 (UPCB); Mazziero et al.968 (UPCB).

13.18. Trichomanes elegans Rich., Actes Soc. Hist. Nat. Paris 1: 114. 1792.

Assemelha-se à $A$. rigidum, sendo as suas diferenças evidenciadas nos comentários desta (item 13.1). Espécie terrícola, encontrada no interior da floresta, em locais sombreados e úmidos.

Material selecionado examinado: Mazziero \& Soller 564 (UPCB); Mazziero \& Soller 565 (UPCB, CAS); Mazziero et al.930 (UPCB, SP, UNIP, NY).

13.19. Trichomanes pellucens Kunze, Linnaea 9: 104. 1834.

Trichomanes plumosum Kunze e Trichomanes robustum E. Fourn., são as espécies brasileiras que mais se assemelham à esta, no entanto, difere por apresentar 1/3-1/2 do pecíolo alado, característica ausente nas outras duas espécies (Windisch, 1992b). Espécie terrícola ou epífita, encontrada em áreas florestais e barrancos às margens de rios (Tryon \& Stolze, 1989a; Windisch 1992b). 
Material selecionado examinado: BRASIL. São Paulo, Mun. Apiaí, Estrada Iporanga-Apiaí, 22.III.1991, P. G. Windisch 6080 (UNISINOS).

13.20. Trichomanes pilosum Raddi, Opusc. Sci. 3: 296. 1819.

Assemelha-se à T. cristatum e suas diferenças são apresentadas nos comentários dessa espécie (item 13.17). Espécie epífita, não encontrada em campo no presente estudo, no entanto, dados disponíveis no Splink (2018) sugerem a ocorrência desta espécies, no Estado de São Paulo, em paredões de arenito, próximos ou não a riachos.

Material selecionado examinado: BRASIL. São Paulo, Mun. Apiaí, s.d., J. J. Puiggari s.n. (RB).

13.21. Trichomanes polypodioides L., Sp. Pl. 2: 1098.1753.

Espécie semelhante à $T$. anadromum e suas diferenças são evidenciadas nos comentários desta última (item 13.16). Espécie epífita, crescendo sobre Cyatheaceae, no interior da floresta, em locais úmidos e sombreados.

Material selecionado examinado: Mazziero \& Soller 639 (UPCB, UNIP, NY); Mazziero \& Soller 670 (UPCB, SP).
13.22. Vandenboschia radicans (Sw.) Copel., Philipp. J. Sci. 67(1): 54. 1938.

As duas espécies do gênero encontradas no Brasil (Windisch, 2015) foram também encontradas no PETAR. São prontamente separadas por $V$. radicans apresentar as pinas bi-pinatissectas ou mais decompostas (vs. pinatífidas a pinatissectas, em $V$. rupestris) e segmentos terminais lineares (vs. levemente flabelados) (Windisch, 2014). Espécie epífita, observada em trilhas e no interior da floresta, em pontos sombreados e úmidos.

Material selecionado examinado: Mazziero \& Soller 566 (UPCB, CAS); Mazziero \& Soller 573 (UPCB); Mazziero \& Soller 582 (UPCB); Mazziero et al. 933 (UPCB, SP, UNIP, NY); Mazziero 1053 (UPCB).

13.23. Vandenboschia rupestris (Raddi) Ebihara \& K. Iwats., Blumea 51(2): 242. 2006.

As diferenças entre esta espécie e $V$. radicans podem ser verificadas nos comentários sobre a última (item 13.22). Espécie epífita, crescendo no interior da floresta, em locais sombreados e úmidos.

Material selecionado examinado: Mazziero \& Soller 604 (UPCB, SP, UNIP, NY).

\section{LINDSAEACEAE}

1. Pecíolo e raque cilíndricos abaxialmente.... 14.1. Lindsaea divaricata.

$1^{\prime}$. Pecíolo e raques angulosos abaxialmente.

2. Porção proximal do pecíolo castanho-escura, porções mediana e distal castanho-claras a estramíneas; pínulas medianas semilunares. 14.2. Lindsaea lancea.

2'. Pecíolo castanho-escuro a nigrescente em toda sua extensão; pínulas medianas trapeziformes. 14.3. Lindsaea quadrangularis.

14.1. Lindsaea divaricata Klotzsch, Linnaea 18: 547. 1844.

Segundo Kramer (1957), esta espécie é caracterizada pelo pecíolo e raque cilíndricos na face abaxial, de coloração castanho-avermelhada, além disso, ocorrem aletas de coloração castanho-clara na raque e raquíola, o tecido laminar apresenta vênulas pouco elevadas e o segmento terminal é amplo e quase sempre estéril. Espécie terrícola, encontrada em locais sombreados no interior da floresta.

Material selecionado examinado: Mazziero \& Albiero Jr. 1075 (UPCB).

14.2. Lindsaea lancea (L.) Beed., Suppl. Ferns S. Ind. 6. 1876.

O material encontrado no PETAR corresponde à $L$. lancea var. lancea. Este, segundo Kramer (1957), separa-se de Lindsaea falcata Dryand. por apresentar pínulas $2-2,5$ vezes mais compri- das do que largas, sendo, as superiores, cerca da metade do comprimento das inferiores e, geralmente, a pínula apical mais longa do que larga (vs. pínulas 3 vezes mais longas do que largas, as superiores pouco ou não reduzidas e pínula apical tão longa quanto larga, em $L$. falcata). Espécie terrícola, encontrada em locais sombreados e úmidos, em barrancos, nas margens de córregos ou no interior da floresta.

Material selecionado examinado: Mazziero \& Soller 657 (UPCB, CAS); Mazziero \& Soller 876 (UPCB, NY); Mazziero et al. 960 (UPCB, SP, UNIP).

14.3. Lindsaea quadrangularis Raddi, Opusc. Sci. 3: 294. 1819.

Kramer (1957) reconhece várias subespécies em Lindsaea quadrangularis. Duas ocorrem no Brasil: L. quadrangularis subsp. antillensis K.U. Kramer e $L$. quadrangularis subsp. quadrangularis Raddi (Prado, 2015). Na área de estudo ocorre L. quadrangularis subsp. terminalis, a qual pode 
ser reconhecida por apresentar as pínulas terminais pouco ou não reduzidas e pínula apical não confluente com as laterais e de tamanho igual ou superior a estas (Kramer, 1957). Espécie terrícola, observada no interior da floresta, em locais sombreados e úmidos.

Material selecionado examinado: Mazziero \& Soller 813 (UPCB, NY); Mazziero \& Soller. 833 (UPCB); Mazziero et al. 927 (UPCB, SP, UNIP); Mazziero 1052 (UPCB).

\section{LOMARIOPSIDACEAE}

15.1. Lomariopsis marginata (Schrad.) Kuhn in Decken, Reis Ost-Afr. Bot. 3(3): 22. 1879.
Segundo Moran (2000), assemelha-se à Lomariopsis japurensis (Mart.) J. Sm., sendo que esta apresenta escamas do caule opacas e entre 8-12 pares de pinas (vs. escamas lustrosas e 1020 pares de pinas, em L. marginata). Espécie hemiepífita (indivíduos férteis), porém, indivíduos estéreis foram registrados como terrícola, epífita ou hemiepífita, nas trilhas ou no interior da floresta, em ambientes sombreados e úmidos.

Material selecionado examinado: Mazziero \& Soller 812 (UPCB, UNIP, NY); Mazziero et al. 948 (UPCB, SP).

\section{LYCOPODIACEAE}

1. Caule ereto ou pendente, ramificado isotomicamente; microfilos não agrupados em estróbilos.

2. Caule ereto; microfilos com a margem denticulada...............................16.9. Phlegmariurus reflexus.

2 '. Caule pendente; microfilos com a margem inteira.

3. Caule nitidamente flexuoso.

16.6. Phlegmariurus flexibilis.

$3^{\prime}$. Caule distintamente reto ou quase reto.

4. Base do caule avermelhada...... 16.7. Phlegmariurus fontinaloides.

$4^{\prime}$. Base do caule de coloração variada, mas nunca avermelhada.

5. Porção basal do caule com microfilos expandidos

5'. Microfilos expandidos ausentes.

6. Microfilos lanceolados.

6'. Microfilos aciculares.

7. Espessura do caule (incluindo os microfilos) diminuindo em direção ao ápice dos ramos........................................................................ Phlegmariurus comans. 7'. Espessura do caule (incluindo os microfilos) igual, desde a base até 0 ápice............................................................................ Phlegmariurus acerosus.

$1^{\prime}$. Caule longo-reptante, ramificado anisotomicamente; microfilos agrupados em estróbilos.

8. Estróbilos surgindo no ápice dos ramos.

9. Estróbilos sésseis.

16.3. Palhinhaea cernua.

9'. Estróbilos longo-pedicelados. 16.2. Lycopodium clavatum.

$8^{\prime}$. Estróbilos surgindo na porção dorsal dos ramos.

10. Microfilos laterais lanceolados.

$10^{\prime}$. Microfilos laterais aciculares. 16.11. Pseudolycopodiella meridionalis. 16.1. Lycopodiella longipes.

16.1. Lycopodiella longipes (Hook. \& Grev.) Holub, Folia Geobot. Phytotx. 26: 93. 1991.

Difere de Lycopodiella tupiana (B. Øllg. \& Windisch) B. Øllg. devido à presença de esporofilos com 5-7 mm de comprimento, linear-lanceolados, laxos, estróbilos com 8-15 mm de largura (esporofilos inclusos) e microfilos com a margem ciliada a denteada nos ramos horizontais (vs. esporofilos com 3,5-6 mm, ovais e cuspidados, estróbilos com 5-10 mm e microfilos dos ramos horizontais com margem finamente denteada, em L. tupiana) (Øllgaard \& Windisch, 2016). Espécie terrícola, encontrada em locais abertos, a pleno sol e solo encharcado.

Material selecionado examinado: Mazziero \& Albiero Jr. 1104 (UPCB, SP, UNIP).

16.2. Lycopodium clavatum L., Sp. PI. 2: 1101. 1753.
Única espécie do gênero no Brasil, e dentre as espécies da subfamília Lycopodioideae, se assemelha à Austrolycopodium erectum (Phillip) Holub, mas difere por apresentar ápice do microfilo incolor e esporofilos subpeltados com uma aurícula basioscópica (vs. ápice foliar verde e esporofilo peltado sem aurículas, em $A$. erectum) (Øllgaard \& Windisch, 2014). Espécie terrícola, observada em locais abertos, exposta ao sol.

Material selecionado examinado: Mazziero \& Albiero Jr. 1107 (UPCB, SP, UNIP, NY, CAS).

16.3. Palhinhaea cernua (L.) Franco \& Vasc., Bol. Soc. Brot., sér. 2, 41: 25. 1967.

Separa-se de Palhinhaea eichleri (Fée) Holub, por esta apresentar os ramos terminais esparsos, longos e pêndulos, bem como microfilos coriáceos (ou quase), curvados e esporofilos denticulados a denteados (vs. ramos terminais agregados, pa- 
tentes, com apenas o ápice curvado, microfilos membranáceos e esporofilos com margens irregularmente denteadas a erosas, em $P$. cernua) (Øllgaard \& Windisch, 2016). Espécie terrícola, encontrada em barrancos nas estradas ou borda da floresta, exposta ao sol, em solo encharcado.

Material selecionado examinado: Mazziero \& Soller 654 (UPCB, SP, UNIP, NY, CAS); Mazziero 991 (UPCB); Mazziero 1046 (UPCB, SP, UNIP).

16.4. Phlegmariurus acerosus (Sw.) B. Øllg., Rodriguésia 63(2): 480. 2012.

Esta espécie assemelha-se à Phlegmariurus comans (Herter ex Nessel) B. Øllg., a qual se distingue por apresentar os ramos afinando em direção às extremidades férteis (vs. ramos com a mesma espessura da base às extremidades, em P. acerosus) (Nessel, 1955; Ramos \& Sylvestre, 2010). Espécie epífita, crescendo no interior da floresta, em locais úmidos.

Material selecionado examinado: Mazziero \& Soller 599 (UPCB, SP).

16.5. Phlegmariurus comans (Herter ex. Nessel) B. Øllg., Rodriguésia 63(2): 480. 2012.

Espécie semelhante à $P$. acerosus, e suas diferenças podem ser vistas nos comentários desta (item 16.4). Espécie epífita, encontrada no interior da floresta, em locais sombreados e úmidos.

Material selecionado examinado: Mazziero \& Engels 1148 (UPCB, SP).

16.6. Phlegmariurus flexibilis (Fée) B. Øllg., Rodriguésia 63(2): 480. 2012.

De acordo com Øllgaard (1992), trata-se de uma espécie semelhante à Phlegmariurus linifolius (L.) B. Øllg., sendo distinguida pelo caule flexuoso (em ziguezague). Espécie epífita, observada no interior da floresta, em locais sombreados.

Material selecionado examinado: Mazziero 1049 (UPCB).

16.7. Phlegmariurus fontinaloides (Spring) B. Øllg., Rodriguésia 63(2): 480. 2012.

Separa-se de $P$. quadrifariatus, sobretudo, por esta apresentar porção basal dos ramos nitidamente quadrangular, a qual é circular em $P$. fontinaloides (Prado \& Hirai, 2008). Espécie epífita, não registrada recentemente no PETAR, mas dados de coletas desta espécies para o Brasil, sugerem sua ocorrência em locais sombreados e úmidos, no interior da floresta (Splink, 2018).

Material selecionado examinado: BRASIL. São Paulo, Mun. Apiaí, I.IX.1881, A. Glaziou 2959 (P).
16.8. Phlegmariurus heterocarpon (Fée) B. Øllg., Rodriguésia 63(2): 480. 2012.

Esta espécie se assemelha à Phlegmariurus loefgrenianus (Silveira) B. Øllg. (Nessel, 1955), no entanto, apresenta microfilos lanceolados, com ápice acuminado e 1-2 mm de largura (vs. microfilos linear-lanceolados atingindo, no máximo, $1 \mathrm{~mm}$ de largura e ápice caudado, em $P$. heterocarpon) (Ramos \& Sylvestre, 2010). Espécie epífita, crescendo em locais sombreados e úmidos, no interior da floresta.

Material selecionado examinado: Mazziero 1048 (UPCB).

16.9. Phlegmariurus reflexus (Lam.) B. Øllg., Rodriguésia 63(2): 481. 2012.

Espécie caracterizada pelo caule ereto, dicotômico e pela margem denteada dos microfilos e esporofilos, os quais são reflexos (Prado \& Hirai, 2008; Ramos \& Sylvestre, 2010). Espécie terrícola, encontrada em barrancos à beira das estradas, em locais úmidos e a pleno sol.

Material selecionado examinado: Mazziero \& Soller 702 (UPCB, SP, UNIP); Mazziero 996 (UPCB, NY).

16.10. Phlegmariurus quadrifariatus (Bory) B. Øllg., Rodriguésia 63(2): 481. 2012.

Espécie semelhante à Phlegmariurus hexastichus (B. Øllg. \& P.G. Windisch) B. Øllg., mas apresenta a porção basal do caule arredondada (microfilos inclusos) e ápice dos esporofilos não conduplicados (vs. caule quadrangular em toda sua extensão e esporofilos com ápice conduplicado, em $P$. quadrifariatus) (Ramos \& Sylvestre, 2010). Espécie epífita, pode ser encontrada em florestas úmidas (Øllgaard \& Windisch, 1987; Windisch et al., 2015).

Material selecionado examinado: BRASIL. São Paulo, Mun. Apiaí, s.d., J. J. Puiggari 102 (P).

16.11. Pseudolycopodiella meridionalis (Underw. \& L. E. Lloyd) Holub, Folia Geobot. Phytotax. 18: 442. 1983.

Separa-se das demais espécies do gênero, encontradas no Brasil, por apresentar a porção do caule prostrada ao solo com mais de $7 \mathrm{~mm}$ de largura, além de microfilos laterais lanceolados a subulados, com 3-7 mm de comprimento e microfilos dorsais subulados a largo-lanceolados (Øllgaard \& Windisch, 2016). Espécie terrícola, encontrada em áreas abertas, a pleno sol e solo encharcado.

Material selecionado examinado: Mazziero \& Albiero Jr. 1105 (UPCB, SP, UNIP, NY).

\section{LYGODIACEAE}

1. Pínulas proximais e distais com o mesmo tamanho 17.2. Lygodium volubile. 
1'. Pínulas gradualmente reduzidas em direção ao ápice da pina (pínula apical com $1 / 2$ do tamanho das proximais)....... 17.1. Lygodium venustum.

17.1. Lygodium venustum Sw., J. Bot. (Schrader) 1801(2): 303. 1803.

Segundo Tryon \& Stolze (1989a) L. venustum assemelha-se à L. volubile, da qual difere pelos pares de pínulas mais numerosos, cujo tamanho reduz em direção ao ápice (vs. pínulas com aproximadamente mesmo tamanho e em menor número de pares, em $L$. volubile). Espécie escandente, observada na borda da mata ou em triIhas, a pleno sol.

Material selecionado examinado: Mazziero \& Soller 879 (UPCB, SP, UNIP).
17.2. Lygodium volubile Sw., J. Bot. (Schrader) 1801(2): 303. 1803.

Semelhante à $L$. venustum, sendo as diferenças entre as duas apresentadas anteriormente (item 17.1). Espécie escandente, encontrada na borda da floresta ou em barrancos junto à beira de estradas, a pleno sol.

Material selecionado examinado: Mazziero \& Soller 878 (UPCB, SP); Mazziero 1055 (UPCB, UNIP).

\section{MARATTIACEAE}

1. Lâmina 1-pinada; frondes dimorfas; sinângios imersos no tecido laminar.

2. Caule curto-reptante, frondes com distribuição dorsiventral; pecíolo sem nós; ápice das pinas com margem crenulada. 18.3. Danaea nodosa.

$2^{\prime}$. Caule ereto, frondes com distribuição radial; pecíolo com 1-3 nós, raro ausente ( $D$. moritziana); ápice das pinas inteiro a denteado.

3. Pinas ovais a lanceoladas; ápice das pinas nitidamente serreado a denteado

.....................................................................................18.2. Danaea moritziana.

3'. Pinas elíptico-oblonga a oblanceolada; ápice das pinas inteiro ou apenas levemente sinuoso.

18.1. Danaea geniculata.

1'. Lâmina 2-pinada ou mais complexa; frondes monomorfas; sinângios na superfície do tecido laminar.

4. Lâmina 2-pinada; sinângios sésseis.....

18.5. Marattia cicutifolia.

4'. Lâmina 3-pinado-pinatífida; sinângios pedicelados.... 18.4. Eupodium kaulfussii.

18.1. Danaea geniculata Raddi, Syn. Fil. Bras. 1: 3 (no. 14). 1819.

Danaea geniculata difere de $D$. moritziana e $D$. nodosa pelas características apresentadas na chave. Além destas três espécies, ocorre no Estado de São Paulo Danaea excurrens Rosenst. (Labiak, 2015), que se separa das demais por apresentar pinas estéreis linear-oblanceoladas, com ápice agudo-acuminado e espatulado, fortemente serreado (características ausentes em $D$. geniculata, D. moritiziana e D. nodosa) (Christenhusz, 2010a). Espécie terrícola, encontrada ao longo de trilhas e no interior da floresta, em locais sombreados e úmidos.

Material selecionado examinado: Mazziero \& Soller 649 (UPCB, NY); Mazziero et al. 936 (UPCB, SP, UNIP).

18.2. Danaea moritziana C. Presl, Abh. Königl. Böhm Ges. Wiss. 5(4): 35. 1845.

A distinção entre as espécies é apresentada na chave e no item 18.1. Espécie terrícola, encontrada nas trilhas e no interior da floresta, em locais sombreados e úmidos.

Material selecionado examinado: Mazziero \& Soller 893 (UPCB, UNIP); Mazziero et al. 968 (UPCB); Mazziero et al. 971 (UPCB, SP).
18.3. Danaea nodosa (L.) Sm., Mém. Acad. Roy. Sci. (Turin) 5: 420. 1793.

Ver os comentários de D. geniculata (item 18.1) para a separação desta espécie das demais do gênero encontradas no Estado de São Paulo. Espécie terrícola, observada em locais úmidos e sombreados no interior da floresta.

Material selecionado examinado: Mazziero \& Soller 851 (UPCB, UNIP, NY, CAS); Mazziero et al. 949 (UPCB, SP).

18.4. Eupodium kaulfussii (J. Sm.) Hook., Sec. Cent. Ferns t. 95. 1870.

Eupodium kaulfussii apresenta lacínios na lâmina em ambas as superfícies (abaxial e adaxial), além disso, o tecido laminar sem escamas ou estas são esparsas e concentradas apenas nas bases dos segmentos primários (Christenhusz, 2010b). Eupodium laevis (Sm.) Murdock é uma espécie semelhante, porém, apresenta lacínios apenas na face adaxial da lâmina e tecido laminar moderadamente escamoso (Christenhusz, 2010b). Espécie terrícola, que cresce no interior da floresta, em pontos sombreados e úmidos.

Material selecionado examinado: Mazziero \& Soller 688 (UPCB, SP); Mazziero et al. 972 (UPCB). 
18.5. Marattia cicutifolia Kaulf., Enum. Filic. 32. 1824.

Segundo Lavalle (2003), esta espécie pode ser reconhecida por apresentar pínula terminal de mesmo tamanho que as laterais, nervuras predo- minantemente geminadas e sinângios supramedianos. Espécie terrícola, encontrada no interior da floresta, em locais úmidos e sombreados.

Material selecionado examinado: Mazziero \& Albiero Jr. 1110 (UPCB, SP, UNIP).

\section{NEPHROLEPIDACAE}

1. Indúsio reniforme, com um sinus estreito e inconspícuo 19.3. Nephrolepis rivularis.

$1^{\prime}$. Indúsio semilunar, sem sinus.

2. Escamas do caule dicromáticas, com a porção central marrom-escura a negra e margem hialina......

19.2. Nephrolepis pendula.

2'. Escamas do caule monocromáticas, ferrugíneas. 19.1. Nephrolepis cordifolia.

19.1. Nephrolepis cordifolia (L.) C. Presl, Tent. Pterid. 79. 1836.

De acordo com Mickel \& Smith (2004), N. cordifolia apresenta caule com ou sem tubérculos, com escamas alaranjadas e inteiras; pecíolo marrom-claro, opaco, com escamas persistentes e fibrosas; raque com escamas bicolores. Já em $N$. pendula, o caule não apresenta tubérculos e suas escamas são castanhas, lustrosas e com margem longamente ciliada; o pecíolo é marrom, lustroso e com poucas escamas persistentes; a raque é glabra ou com esparsas escamas concolores na base das pinas. Espécie epífita, encontrada ao longo das trilhas, em locais úmidos e ensolarados.

Material selecionado examinado: Mazziero 1068 (UPCB, SP).

19.2. Nephrolepis pendula (Raddi) J. Sm., J. Bot. (Hooker) 4: 197. 1841.
Semelhante à $N$. cordifolia, suas características principais estão mostradas nos comentários dessa espécie (item 19.1). Espécie epífita ou terrícola, crescendo em locais abertos e expostos ao sol, em trilhas e às margens de córregos.

Material selecionado examinado: Mazziero \& Soller 613 (UPCB); Mazziero \& Soller 635 (UPCB, $\mathrm{SP})$.

19.3. Nephrolepis rivularis (Vahl) Mett. ex Krug in Urban, Bot. Jahrb. Syst. 24: 122. 1897.

Separa-se das outras espécies do gênero, pelo indúsio reniforme, castanho-escuro a marrom, com sinus estreito, dando aspecto peltado ao indúsio e raque densamente coberta por escamas persistentes (Hovenkamp \& Miyamoto, 2005). Espécie epífita, crescendo em ambientes ensolarados e úmidos, nas trilhas.

Material selecionado examinado: Mazziero \& Soller 855 (UPCB, SP).

\section{OPHIOGLOSSACEAE}

1. Plantas epífitas; frondes pendentes, com dois ou mais sinângios; lâmina sulcada

1'. Plantas terrícolas; frondes eretas, com um único sinângio; lâmina inteira

20.1. Cheiroglossa palmata. 20.2. Ophioglossum reticulatum.

20.1. Cheiroglossa palmata (L.) C. Presl, Suppl. Tent. Pterid. 56. 1845(1846).

Trata-se de uma espécie de fácil reconhecimento, por apresentar hábito epifítico e pela lâmina palmatilobada, com sinângios reunidos em sua base (Prado, 2004). Espécie epífita, encontrada no interior da floresta, em locais sombreados e úmidos.

Material selecionado examinado: Mazziero 999 (UPCB).

20.2. Ophioglossum reticulatum L., Sp. PI. 2: 1063. 1753.
Difere de Ophioglossum nudicaule L.f. pela base cordada ou truncada da lâmina estéril, raro abruptamente cuneada e aréolas primárias englobando aréolas secundárias ou vênulas livres, enquanto, $O$. nudicaule apresenta base da lâmina estéril cuneada e sem vênulas ou aréolas inclusas nas aréolas primárias (Tryon \& Stolze, 1989a). Espécie terrícola, associada a ambientes abertos e solo úmido.

Material selecionado examinado: BRASIL. São Paulo, Mun. Apiaí, 1.III.1883, A. Lofgren $2848(P)$. 


\section{OSMUNDACEAE}

1. Frondes hemidimorfas; lâmina 2-pinada.....

21.1. Osmunda regalis.

1'. Frondes dimorfas; lâmina 1-pinado-pinatífida. 21.2. Osmundastrum cinnamomeum.

21.1. Osmunda regalis L., Sp. PI. 2: 10651066. 1753.

Esta espécie separa-se de 0 . cinnamomeum pelas características da chave. Espécie rupícola ou terrícola, encontrada em locais abertos, como barranco de estradas, a pleno sol e em solo encharcado.

Material selecionado examinado: Mazziero \& Soller 690 (UPCB); Mazziero 1004 (UPCB, SP).
21.2. Osmundastrum cinnamomeum (L.) C. Presl, Gefässbündel Farrn 18. 1847.

Distingue-se de $O$. regalis pelas características propostas na chave. Espécie terrícola, ocorre em locais sombreados ou exposta ao sol, com solo úmido a encharcado.

Material selecionado examinado: BRASIL. São Paulo, Mun. Apiaí, 14.IV.1977, H.F. Leitão FiIho 4746 (MBM).

\section{POLYPODIACEAE}

1. Frondes contínuas ao caule, sem filopódio.

2. Lâmina com até $0,5 \mathrm{~cm}$ de largura.

3. Escamas do caule clatradas; soros presentes em toda extensão da lâmina; porção fértil da lâmina plana..... 22.10. Leucotrichum schenckii.

3'. Escamas do caule não clatradas; lâmina fértil apenas na porção distal; porção fértil da lâmina conduplicada.

4. Porção estéril da lâmina pinatissecta.

22.8. Cochlidium serrulatum. $4^{\prime}$. Porção estéril da lâmina inteira.

22.7. Cochlidium punctatum.

$2^{\prime}$. Lâmina com mais de $1 \mathrm{~cm}$ de largura.

5. Lâmina com crescimento indeterminado; frondes pendentes.

22.1. Alansmia reclinata.

$5^{\prime}$. Lâmina com crescimento determinado; frondes eretas.

6. Setas castanhas ausentes no pecíolo e lâmina.

22.9. Lellingeria apiculata.

$6^{\prime}$. Setas castanhas presentes no pecíolo e tecido laminar.

7. Escamas do caule clatradas.

22.11. Melpomene peruviana.

$7^{\prime}$. Escamas do caule não clatradas.

$1^{\prime}$. Frondes articuladas ao caule, com filopódio.

8. Lâmina inteira.

9. Soros dispostos em duas ou mais fileiras entre a costa e a margem.

10. Aréolas formando uma fileira entre as nervuras secundárias............22.18. Niphidium crassifolium. 10 . Aréolas formando duas ou mais fileiras entre as nervuras secundárias.

11. Lâmina coriácea.

12. Tecido laminar com nervuras secundárias imersas; 2-3 fileiras de aréolas entre a costa e a margem ....................................................................22.6. Campyloneurum rigidum.

12 '. Tecido laminar com nervuras proeminentes, ao menos, na face abaxial; 4-7 fileiras de aréolas entre a costa e a margem

22.5. Campyloneurum nitidum.

11'. Lâmina membranácea a cartácea.

13. Nervuras secundárias sinuosas, partindo da costa em ângulo menor que 650; 3-6 aréolas entre a costa e a margem

22.2. Campyloneurum atlanticum.

13'. Nervuras secundárias retilíneas, partindo da costa em ângulo maior que $65^{\circ} ; 7-12$ aréolas entre a costa e a margem.

22.3. Campyloneurum crispum.

9'. Soros dispostos em uma fileira entre a costa e a margem.

14. Frondes hemidimorfas.

15. Face abaxial da lâmina densamente coberta por escamas, distribuídas de maneira uniforme por toda sua extensão. 22.15. Microgramma tecta.

15'. Face abaxial da lâmina com escamas esparsas, presentes em maior número próximo à costa, raras sobre o tecido laminar.

16. Soros surgindo sobre apenas uma vênula; escamas costais filiformes ou aracnoides..........................................................................22.16. Microgramma vacciniifolia.

16 '. Soros surgindo sobre 2-3 vênulas; escamas costais lanceoladas.......................................................................22.14. Microgramma squamulosa.

$14^{\prime}$. Frondes monomorfas.

17. Escamas do caule não clatradas; soros arredondados.

18. Lâmina lanceolada, com ápice agudo; face abaxial glabra ou apenas com escamas filiformes esparsas presentes na costa. 
18'. Lâmina linear, com ápice longamente atenuado; face abaxial com escamas orbiculares a circulares. 22.13. Microgramma percussa.

17 . Escamas do caule clatradas; soros lineares, oblongos ou arredondados.

19. Escamas do caule lanceoladas, dicromáticas (porção central negra e margem alva), glabra; soros arredondados. 22.28. Pleopeltis macrocarpa.

19'. Escamas do caule circulares a ovais, monocromáticas (castanho-escuras), com cílios longos na porção central; soros lineares a oblongos.

22.25. Pleopeltis astrolepis.

8'. Lâmina pseudodicotomicamente furcada, pinatissecta a 1-pinada.

20. Soros lineares.....

22.26. Pleopeltis furcata.

$20^{\prime}$. Soros circulares.

21. Raque adaxialmente cilíndrica.

22. Base da lâmina truncada, sem pinas basais reduzidas.

22.21. Pecluma recurvata.

22 '. Base da lâmina gradualmente reduzida.

23. Nervuras predominantemente simples.

24. Segmentos patentes, com até $0,2 \mathrm{~cm}$ de largura....

22.23. Pecluma sicca.

24 '. Segmentos ascendentes, com até $0,5 \mathrm{~cm}$ de largura.

22.24. Pecluma truncorum.

23'. Nervuras predominantemente furcadas.

25. Tricomas na face abaxial da lâmina em maior concentração próximo aos soros; nervuras proximais 2-furcadas..... 22.22. Pecluma robusta.

25'. Tricomas distribuídos igualmente por toda a face abaxial da lâmina; nervuras proximais 1-furcadas. 22.20. Pecluma pectinatiformis.

$21^{\prime}$. Raque adaxialmente sulcada.

26. Soros imaturos densamente cobertos por escamas.

27. Lâmina 1-pinada; aeróforos presentes na base acroscópica da pina.

22. 27 . Pleopeltis hirsutissima.

27'. Lâmina pseudodicotomicamente furcada a pinatissecta; aeróforos ausentes.

28. Inserção dos segmentos na raque formando um ângulo agudo.............................................................................22.30. Pleopeltis pleopeltifolia.

$28^{\prime}$. Inserção dos segmentos na raque formando um ângulo reto.....22.29. Pleopeltis pleopeltidis.

$26^{\prime}$. Soros imaturos não cobertos por escamas.

29. Nervuras livres.

22.19. Pecluma chnoophora.

29 . Nervuras anastomosadas.

30. Aréolas medianas com 2-3 vênulas inclusas.

22.4. Campyloneurum decurrens.

$30^{\prime}$. Aréolas medianas com apenas uma vênula inclusa.

31. Lâmina 1-pinada.

32. Pinas lineares; costa abaxial com escamas ovais........22.34. Serpocaulon menisciifolium.

32'. Pinas lanceoladas; costa abaxial com escamas lineares a glabra..................................................................22.32. Serpocaulon fraxinifolium.

31'. Lâmina pinatissecta.

33. Caule com depósitos de cera branca; escamas costais lineares, ramificadas e não clatradas. 22.31. Serpocaulon catharinae.

33'. Caule sem depósitos de cera; escamas costais linear-lanceoladas, inteiras e clatradas. 22.33. Serpocaulon latipes.

22.1. Alansmia reclinata (Brack.) Moguel \& $M$. Kessler, Brittonia 63(2): 241. 2011.

Espécie semelhante à Alansmia cultrata (Bory ex Willd.) Moguel \& M. Kessler, porém, esta apresenta escamas do caule com até $0,1 \mathrm{~cm}$ de comprimento e base dos segmentos simétrica ou pouco assimétrica (vs. escamas com 0,2-0,3 cm de comprimento e base dos segmentos nitidamente assimétrica, em $A$. reclinata) (Labiak \& Prado, 2005a). Espécie epífita, encontrada no interior da floresta, em locais úmidos e sombreados.

Material selecionado examinado: Mazziero \& Albiero Jr. 1130 (UPCB).

22.2. Campyloneurum atlanticum R. C. Moran \& Labiak, Am. Fern J. 107: 3. 2017.
Pode ser reconhecida pela lâmina com 2-4,3 $\mathrm{cm}$ de largura, pecíolo com 3,5-10 cm de comprimento e caule longo-reptante com escamas ovais, castanho-claras a quase alaranjadas (Labiak et al., 2017). Espécie rupícola ou epífita, encontrada nas trilhas e no interior da floresta, em locais sombreados e úmidos.

Material selecionado examinado: Mazziero \& Soller 589 (UPCB); Mazziero \& Soller 883 (UPCB, CAS); Mazziero \& Soller 884 (UPCB, UNIP, NY); Mazziero et al. 982 (UPCB, SP).

22.3. Campyloneurum crispum Fée, Mém. Foug. 5. Gen. Filic. 259. 1852.

Pode ser confundida com C. atlanticum e Campyloneurum herbaceum (Christ) Ching, porém, C. crispum apresenta frondes, geralmente, 
maiores que $120 \mathrm{~cm}$ de comprimento e caule curto-reptante (vs. caules longo-reptantes e lâminas atingindo, no máximo, $43 \mathrm{~cm}$ em $C$. herbaceum e $51 \mathrm{~cm}$ em C. atlanticum) (Labiak et al., 2017). Espécie terrícola ou epífita, encontrada ao longo das trilhas no interior da floresta, em locais sombreados e úmidos.

Material selecionado examinado: Mazziero \& Soller 592 (UPCB, UNIP, NY, CAS); Mazziero et al. 962 (UPCB, SP).

22.4. Campyloneurum decurrens (Raddi) C. Presl, Tent. Pterid. 190. 1836.

Moran \& Labiak (2016) indicaram a presença de lâmina 1-pinada em três espécies, sendo uma delas $C$. decurrens. Ainda de acordo com estes autores, esta espécie difere de Campyloneurum pentaphyllum (Willd.) Pic. Serm., por apresentar pinas distais sésseis e amplamente decurrentes, em contraposição à presença de pinas distais sésseis, pouco ou nada decurrentes (C. pentaphyllum). Espécie rupícola, encontrada crescendo às margens de córregos, em local sombreado.

Material selecionado examinado: Mazziero \& Soller 919 (UPCB, SP, UNIP, NY).

22.5. Campyloneurum nitidum (Kaulf.) C. Presl, Tent. Pterid. 190. 1836.

Segundo León (1992), Campyloneurum phyllitidis (L.) C. Presl é uma espécie semelhante, diferindo principalmente pelo caule com diâmetro variando entre 6-15 mm, com escamas de ápice acuminado e lâmina subcaudada a acuminada no ápice, ao passo que, C. nitidum apresenta caule com 3-4 mm de diâmetro, ápice das escamas do caule obtuso e ápice da lâmina atenuado. Espécie terrícola ou epífita, observada nas trilhas e no interior da floresta, em locais úmidos e sombreados.

Material selecionado examinado: Mazziero \& Soller 601 (UPCB); Mazziero \& Soller 664 (UPCB); Mazziero \& Soller 611 (UPCB, CAS); Mazziero et al. 977 (UPCB, SP, UNIP, NY); Mazziero 1037 (UPCB, SP, UNIP, CAS).

22.6. Campyloneurum rigidum J. Sm., Cat. Kew Ferns 2. 1856.

De acordo com Vasques \& Prado (2011), em Campyloneurum fallax Fée o caule é longo-reptante e apresenta 4-5 aréolas entre a costa e a margem da lâmina, por sua vez, $C$. rigidum apresenta caule curto-reptante e 2-3 aréolas entre a costa e a margem da lâmina. Espécie epífita, crescendo ao longo das trilhas e no interior da floresta, em ambientes sombreados e úmidos.

Material selecionado examinado: Mazziero \& Soller 846 (UPCB, SP); Mazziero et al. 981 (UPCB).
22.7. Cochlidium punctatum (Raddi) L.E. Bishop, Amer. Fern J. 68(3): 86. 1978.

Segundo Labiak \& Prado (2003), esta espécie é semelhante à Cochlidium pumilum C. Chr., da qual difere por apresentar nervuras 1-furcadas e lâmina com 3-4 mm de largura (em C. pumilum, as nervuras são simples e a lâmina tem aproximadamente 1,5 mm de largura). Espécie epífita, encontrada em locais úmidos e ensolarados, das trilhas e estradas.

Material selecionado examinado: Mazziero 1028 (UPCB).

22.8. Cochlidium serrulatum (Sw) L.E. Bishop, Amer. Fern J. 68(3): 80. 1978.

Dentre as espécies brasileiras que exibem porção fértil da lâmina conduplicada, C. serrulatum separa-se pela porção estéril da lâmina pinatissecta, a qual é inteira nas demais espécies (Labiak \& Prado, 2003). Espécie epífita, crescendo em locais sombreados e úmidos, no interior da floresta.

Material selecionado examinado: Mazziero 1057 (UPCB).

22.9. Lellingeria apiculata (Kunze ex Klotzsch) A. R. Sm. \& R. C. Moran, Amer. Fern J. 81(3): 83. 1991.

Dentre as espécies brasileiras de Lellingeria, a mais semelhante é Lellingeria hirsuta A. R. Sm. \& R. C. Moran, porém, esta espécie apresenta raque glabra ou com tricomas esparsos na face abaxial, enquanto, L. apiculata apresenta a raque pubescente em ambas as faces (Labiak \& Prado, 2005b). Espécie epífita, encontrada no interior de florestas, em locais sombreados e úmidos (Labiak \& Prado, 2005b).

Material selecionado examinado: BRASIL. São Paulo, Mun. Apiaí, s.d., J. J. Puiggari s.n. (RB).

22.10. Leucotrichum schenckii (Hieron.) Labiak, Taxon 59(3): 920, f. 3I-L. 2010.

Duas espécies são encontradas no Brasil, sendo separadas de Leucotrichum organense (Gardner) Labiak por apresentar a lâmina pinatífida, com até $0,6 \mathrm{~cm}$ de largura e incisões atingindo $1 / 3$ a 1/4 da distância entre a margem e a raque (vs. lâmina pinatissecta, com até $0,4 \mathrm{~cm}$ de largura e incisões alcançando $2 / 3$ a 3/4 da distância entre a margem e a raque, em $L$. schenckii) (Labiak et al., 2010). Espécie epífita, observada no interior da floresta, em locais sombreados e úmidos.

Material selecionado examinado: Mazziero \& Albiero Jr. 1123 (UPCB).

22.11. Melpomene peruviana (Desv.) A. R. Sm. \& R. C. Moran, Novon 2(4): 430. 1992. 
Assemelha-se à Melpomene flabeliformis (Poir.) A. R. Sm. \& R. C. Moran., porém, apresenta a raque com setas na face adaxial, as quais são ausentes em M. flabeliformis (Labiak \& Prado, 2005c). Espécie rupícola, encontrada em áreas montanhosas de Floresta Atlântica (Labiak \& Prado, 2005c).

Material selecionado examinado: BRASIL. São Paulo, Mun. Apiaí, s.d., J. J. Puiggari 2408 (P).

22.12. Microgramma geminata (Schrad.) R.M. Tryon \& A. F. Tryon, Rhodora 84: 129. 1982.

Separa-se de Microgramma thurnii (Baker) R.M. Tryon. por apresentar soros impressos, frondes com ápice agudo a acuminado e nervuras pouco evidentes a obscurecidas (vs. soros não impressos, ápice das frondes caudado, raro acuminado e nervuras evidentes, em $M$. thurnii) (Almeida, 2017). Espécie epífita, encontrada às margens das estradas, em local seco e ensolarado.

Material selecionado examinado: Mazziero 1066 (UPCB, SP, UNIP).

22.13. Microgramma percussa (Cav.) de la Sota, Physis (Buenos Aires) 44 (106C): 28. 1986.

Espécie caracterizada pela lâmina com ápice longo acuminado, de consistência coriácea, com escamas arredondadas e paráfises filiformes em grande quantidade nos soros (Mickel \& Smith, 2004). Espécie rupícola ou epífita, encontrada no interior da floresta, em pontos sombreados ou ensolarados, úmidos.

Material selecionado examinado: Mazziero \& Soller 606 (UPCB); Mazziero \& Soller 641 (UPCB, SP, UNIP); Mazziero \& Soller 642 (UPCB, NY, CAS).

22.14. Microgramma squamulosa (Kaulf.) de la Sota, Opera Lilloana 5: 59, fig. 2, 3, 6, 7. 1961.

Separa-se de M. vacciniifolia por esta apresentar escamas caulinares com margem denteada, lâmina com base cuneada a truncada e soros crescendo sobre apenas uma vênula, enquanto, em M. squamulosa, as escamas caulinares possuem margem ciliada, lâmina com base truncada e soros crescendo sobre 2-3 vênulas (Prado et al., 2010; Sota, 1960). Espécie epífita, encontrada na borda da floresta, em locais ensolarados e úmidos.

Material selecionado examinado: Mazziero \& Soller 697 (UPCB).

22.15. Microgramma tecta (Kaulf.) Alston, $\mathrm{J}$. Wash. Acad. Sci. 48: 232. 1958.

Espécie semelhante à Microgramma pilosseloides (L.) Copel., a qual apresenta lâmina fértil elíptica (vs. oblonga, em M. tecta) e Microgramma reptans (Cav.) A. R. Sm., que apresenta os soros projetando-se para fora do tecido laminar, o que não ocorre em M. tecta (Mickel \& Smith, 2004). Espécie rupícola ou epífita, observada na borda da floresta, beiras de estradas e trilhas, em locais úmidos e expostos ao sol.

Material selecionado examinado: Mazziero \& Soller 608 (UPCB, UNIP); Mazziero \& Soller 888 (UPCB, SP).

22.16. Microgramma vacciniifolia (Langsd. \& Fisch.) Copel., Gen Fil. (Copeland) 185. 1947.

Microgramma vacciniifolia é uma espécie semelhante à $M$. squamulosa, sendo as diferenças entre elas indicadas nos comentários sobre a segunda (item 22.15). Espécie epífita, encontrada na beira das estradas, em locais sombreados e úmidos.

Material selecionado examinado: Mazziero \& Engels 1172 (UPCB).

22.17. Moranopteris achilleifolia (Kaulf.) R.Y. Hirai \& J. Prado, Taxon 60(4): 1128. 2011.

De acordo com Labiak \& Hirai (2015), esta espécie caracteriza-se pelos segmentos com mais de dois soros, lâminas pinatissecto-pinatífidas até 2-pinatissecta, venação pinada, terminando em hidatódio e caule curto-reptante, com escamas de margem inteira. Espécie epífita, encontrada em áreas florestais, associadas, geralmente, a líquens e briófitas (Labiak \& Prado, 2005a).

Material selecionado examinado: BRASIL. São Paulo, Mun. Apiaí, V.1885, J. J. Puiggari s.n. (SP).

22.18. Niphidium crassifolium (L.) Lellinger, Amer. Fern J. 62: 106. 1972.

Segundo Lellinger (1972), esta espécie distingue-se de Niphidium rufosquamatum Lellinger, por apresentar escamas nitidamente clatradas, bicolores e de margem inteira, enquanto, em $N$. rufosquamatum, as escamas são fracamente clatradas, concolores e com margem denteada a erosa. Espécie epífita, observada nas trilhas e no interior da floresta, em locais úmidos e sombreados.

Material selecionado examinado: Mazziero \& Soller 662 (UPCB, SP, UNIP, NY).

22.19. Pecluma chnoophora (Kunze) Salino \& Costa-Assis, Darwiniana 45(2): 239. 2007.

Espécie reconhecida pela presença de lâmina membranácea, com pinas patentes e revestidas por tricomas hialinos articulados (Sehnem, 1970). Espécie terrícola, habitando locais sombreados e úmidos, nas trilhas ou às margens de riachos.

Material selecionado examinado: Mazziero \& Soller 585 (UPCB, SP); Mazziero \& Soller 828 (UPCB); Mazziero 1058 (UPCB). 
22.20. Pecluma pectinatiformis (Lindm.) $M$. G. Price, Amer. Fern J. 73(4): 115. 1983.

Assemelha-se à Pecluma paradiseae (Langsd. \& Fisch) M. G. Price, que possui frondes maiores que $70 \mathrm{~cm}$ de comprimento, com segmentos falcados, fortemente crenados e soros marginais (em $P$. pectinatiformis, as frondes atingem até $65 \mathrm{~cm}$ de comprimento, os segmentos são reflexos, com margem inteira e soros supramedianos) (Evans, 1969). Espécie epífita, encontrada no interior da floresta, em locais ensolarados e úmidos.

Material selecionado examinado: Mazziero et al. 953 (UPCB).

22.21. Pecluma recurvata (Kaulf.) M. G. Price, Amer. Fern J. 73(4): 115. 1983.

Segundo Evans (1969), esta espécie é semelhante à Pecluma hygrometrica (Splitg.) M. G. Price, que não ocorre no Brasil. Das principais diferenças entre as espécies, estão a presença de vênulas 1 -furcadas e segmentos obtusos em $P$. hygrometrica (vs. vênulas 2-furcadas e segmentos acuminados, em $P$. recurvata) (Evans, 1969). Espécie epífita, encontrada nas trilhas, exposta ao sol.

Material selecionado examinado: Mazziero \& Soller 621 (UPCB, UNIP, NY, CAS); Mazziero \& Soller 918 (UPCB, SP).

22.22. Pecluma robusta (Fée) M. Kessler \& $A$. R. Sm., Candollea 60(1): 281. 2005.

Pode ser separada de Pecluma pilosa (A.M. Evans) M. Kessler \& A. R. Sm., por apresentar segmentos maiores $(4,2-9,8 \times 0,48-0,97 \mathrm{~cm})$, com ápice arredondado ou cuneado (vs. segmentos menores, 1,4-3,9 x 0,31-0,46 cm, com ápice arredondado, em $P$. pilosa) (Assis \& Salino, 2017). Espécie terrícola, sendo encontrada em locais ensolarados, nas bordas e trilhas da floresta.

Material selecionado examinado: Mazziero \& Soller 830 (UPCB, SP, UNIP); Mazziero 1040 (UPCB, NY, CAS).

22.23. Pecluma sicca (Lindm.) M. G. Price, Amer. Fern J. 73(4): 115. 1983.

Espécie semelhante à $P$. truncorum, porém, distingue-se por apresentar segmentos patentes, com 1-2 mm de largura e escamas do caule marrom-avermelhadas (em $P$. truncorum, os segmentos são ascendentes, $65^{\circ}-75^{\circ}$ em relação à raque, mais largos que $2 \mathrm{~mm}$ e as escamas do caule são marrom-escuras; Evans, 1969). Espécie epífita que, apesar de não ter sido encontrada recentemente na área de estudo, dados de coletas no Estado de São Paulo indicam sua ocorrên- cia para áreas úmidas no interior das florestas (Splink, 2018).

Material selecionado examinado: BRASIL. São Paulo, Mun. Apiaí, s.d., J. J. Puiggari 2341 (RB).

22. 24. Pecluma truncorum (Lindm.) M. G. Price, Amer. Fern J. 73(4): 115. 1983.

Espécie que lembra $P$. sicca, sendo suas diferenças evidenciadas nos comentários desta última (item 22.24). Espécie epífita, encontradas em locais sombreados e úmidos, nas trilhas e no interior da floresta.

Material selecionado examinado: Mazziero \& Soller 607 (UPCB, CAS); Mazziero \& Soller 917 (UPCB, SP, UNIP, NY).

22. 25. Pleopeltis astrolepis (Liebm.) E. Fourn., Mex. PI. 1: 87. 1872.

Dentre as espécies de Pleopeltis com lâmina inteira, difere por apresentar soros oblongos e pecíolo curto ou ausente (Mickel \& Smith, 2004). Segundo Rolim \& Salino (2008), esta espécie pode ser distinguida de $P$. macrocarpa pela presença de escamas ciliadas concolores no caule, obscurecidas por tricomas, por sua vez, P. macrocarpa apresenta o caule com escamas bicolores, desprovidas de cílios e não obscurecidas por tricomas. Espécie epífita, observada em trilhas, bordas, margens de estradas e no interior da floresta, em locais sombreados até expostos ao sol e úmidos.

Material selecionado examinado: Mazziero \& Soller 574 (UPCB); Mazziero \& Soller 887 (UPCB); Mazziero 1013 (UPCB).

22.26. Pleopeltis furcata (L.) A. R. Sm., Bot. Sci. 92(1): 46. 2014.

Semelhante à Pleopeltis desvauxii (Klotzsch) Salino, contudo, esta última apresenta a porção estéril dos segmentos com nervuras anastomosadas, as quais são livres em $P$. furcata (Smith, 1995). Espécie epífita, encontrada no interior da floresta, em pontos sombreados.

Material selecionado examinado: Mazziero \& Soller 841 (UPCB); Mazziero \& Soller 849 (UPCB).

22. 27. Pleopeltis hirsutissima (Raddi) de la Sota, Darwiniana 45: 239. 2007.

Segundo Assis \& Labiak (2009), Pleopeltis bombycina (Maxon) A. R. Sm. é semelhante à $P$. hirsutissima, no entanto, possui lâmina apenas com escamas gonfóides (vs. escamas gonfóides e lanceoladas, em $P$. hirsutissima). Espécie epífita, encontrada nas trilhas e borda da floresta, exposta ao sol ou na sombra.

Material selecionado examinado: Mazziero \& Soller 567 (UPCB); Mazziero \& Soller 600 (UPCB, $\mathrm{SP})$; Mazziero \& Soller 640 (UPCB). 
22.28. Pleopeltis macrocarpa (Bory ex Willd.) Kaulf., Berlin. Jahrb. Pharm. Verbundenen Wiss. 21: 41.1821.

Espécie semelhante à $P$. astrolepis, principalmente devido à presença de lâmina simples (ver distinção entre elas no comentário sobre esta última, item 22.26). Espécie epífita, observada em trilhas e no interior da floresta, em pontos úmidos e ensolarados.

Material selecionado examinado: Mazziero 1006 (UPCB, SP); Mazziero 1031 (UPCB).

22.29. Pleopeltis pleopeltidis (Fée) de la Sota, Darwiniana 45(2): 239. 2007.

Espécie semelhante à $P$. pleopeltifolia, da qual pode ser separada, segundo Schwartsburd \& Labiak (2007), por apresentar os segmentos patentes à raque (cerca de $70-90^{\circ}$ ) e a lâmina não palmatilobada (em $P$. pleopeltifolia, os segmentos são oblíquos à raque, formando ângulo de aproximadamente $45^{\circ}$ e a lâmina é palmatilobada). Espécie epífita, encontrada no interior da floresta e às margens de estradas, em locais sombreados e úmidos.

Material selecionado examinado: Mazziero 1019 (UPCB, SP, UNIP, NY); Mazziero \& Albiero Jr. 1088 (UPCB).

22.30. Pleopeltis pleopeltifolia (Raddi) Alston, Bol. Soc. Brot. 30: 21. 1956.

Pleopeltis pleopeltifolia é semelhante à $P$. pleopeltidis, sendo as diferenças entre as duas evidenciadas nos comentários desta última (item 22.30). Espécie epífita, encontrada nas trilhas, no interior e nas e bordas da floresta, em locais úmidos, sombreados ou a pleno sol.

Material selecionado examinado: Mazziero \& Soller 646 (UPCB, SP, UNIP); Mazziero 989 (UPCB, NY, CAS); Mazziero 1032 (UPCB, SP).

22.31. Serpocaulon catharinae (Langsd. \& Fisch.) A. R. Sm., Taxon 55(4): 928. 2006.

Serpocaulon catharinae pode ser confundida com Serpocaulon latipes (Langsd. \& Fisch.) A. R. Sm., distinguindo-se por apresentar rizoma rugoso (depois de seco), com depósito de cera branca, escamas do caule marrom-escuras e opacas (em S. latipes, o rizoma não é rugoso depois de seco, não apresenta depósitos cerosos e as escamas são marrom-claras e brilhantes) (Labiak \& Prado, 2008). Espécie epífita, encontradas nas trilhas ou no interior da floresta, em ambientes úmidos e expostos ao sol.

Material selecionado examinado: Mazziero \& Soller 652 (UPCB, NY); Mazziero \& Soller 814
(UPCB, SP, UNIP); Mazziero \& Albiero Jr. 1084 (UPCB).

22.32. Serpocaulon fraxinifolium (Jacq.) A. R. Sm., Taxon 55(4): 928, f. 3C,G,F, f. 4G-K. 2006.

Trata-se de uma espécie semelhante à Serpocaulon triseriale (Sw.) A. R. Sm. e S. menisciifolium, das quais se separa pelas pinas medianas sésseis, mas não adnatas, enquanto as outras duas apresentam as pinas adnatas à raque, pelo menos, no lado acroscópico (Labiak \& Prado, 2008). Espécie epífita, em locais sombreados e úmidos, no interior da floresta.

Material selecionado examinado: Mazziero 1024 (UPCB); Mazziero 1136 (UPCB).

22.33. Serpocaulon latipes (Langsd. \& Fisch.) A. R. Sm., Taxon 55(4): 928. 2006.

Espécie semelhante à $S$. catharinae e a distinção entre elas já fora apresentada nos comentários desta última (item 22.32). Pode também ser confundida com Serpocaulon vacillans (Link) A. R. Sm., que, no entanto, apresenta tricomas na superfície laminar, ausentes em $S$. latipes (Labiak \& Prado, 2008). Espécie terrícola, ocorrendo no interior da floresta, em ambientes sombreados e úmidos.

Material selecionado examinado: Mazziero \& Albiero Jr. 1114 (UPCB, SP).

22.34. Serpocaulon menisciifolium (Langsd. \& Fisch.) A. R. Sm., Taxon 55(4): 928. 2006.

Espécie semelhante à Serpocaulon triseriale (Sw.) A. R. Sm. e Serpocaulon rex Schwartsb. \& A. R. Sm. (Schwartsburd \& Smith, 2013). Da primeira se separa pela presença de tricomas e escamas ovais a lanceoladas na face abaxial da raque e da costa e, na face adaxial, apresenta tricomas hialinos (vs. ambas as faces glabras, ou apenas escamas lineares e tricomas marrom-avermelhados esparsos na face abaxial, em $S$. triseriale) (Labiak \& Prado, 2008). De S. rex, difere por ser epífita, ter frondes arqueadas, pinas basioscopicamente séssil e acroscopicamente adnatas, além de 1-3 fileiras de soros de cada lado da costa (vs. hábito terrícola, frondes eretas, pinas basioscopicamente pecioluladas e acroscopicamente sésseis, além de 4-6 fileiras de soros de cada lado da costa, em S. rex) (Schwartsburd \& Smith, 2013). Espécie rupícola ou epífita, encontrada nas trilhas, crescendo a pleno sol.

Material selecionado examinado: Mazziero \& Engels, 1154 (UPCB).

\section{PSILOTACEAE}

23.1. Psilotum nudum (L.) P. Beauv., Prodr. Aethéogam. 106, 112. 1805.

Separa-se de Psilotum complanatum Sw., por esta última apresentar ramos achatados e mais largos que $2 \mathrm{~mm}$, enquanto, em $P$. nudum, os ramos são 3-angulados e com 1-2 mm de largura 
(Tryon \& Stolze, 1994). Espécie epífita, rupícola ou terrícola (Gissi, 2017) que ocorre em locais úmidos nas florestas (Palacios-Rios, 1987).
Material selecionado examinado: BRASIL. São Paulo, Mun. Iporanga, Gruta das areias, Lajeado - Vale do Ribeira, X.1996, D. P. Saridakis et al. s.n. (FUEL).

\section{PTERIDACEAE}

1. Soros abaxiais.

2. Soros percorrendo toda a extensão das nervuras secundárias.

3. Face abaxial desprovida de substância cerosa branca.

24.31. Tryonia myriophylla.

3'. Face abaxial conspicuamente coberta por uma cera branca.

4. Pinas distais 1 -pinadas, lineares.

24.19. Pityrogramma trifoliata.

4'. Pinas distais 1-pinado-pinatífidas, deltoides. 24.18. Pityrogramma calomelanos.

$2^{\prime}$. Soros lineares, paralelos à nervura central.

5. Duas fileiras de soros de cada lado da costa.

24.20. Polytaenium lineatum.

5'. Uma fileira de soros de cada lado da costa.

6. Frondes com pecíolos conspícuos; célula apical das paráfises infundibuliforme..................................................................24.30. Radiovittaria stipitata.

6'. Frondes sésseis ou curtamente pecioladas; célula apical das paráfises claviforme.

7. Paráfises castanho-claras, com célula apical filiforme...........................24.33. Vittaria lineata.

7'. Paráfises castanho-escuras a avermelhadas, com célula apical clavifor-

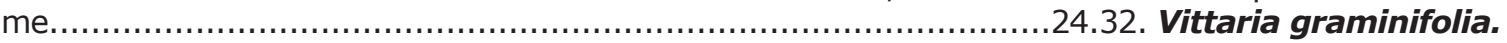

$1^{\prime}$. Soros marginais.

8. Lâmina simples.

9. Lâmina inteira, lobada apenas na base; lanceolada; lobos basais inteiros, voltados para trás, dando aspecto sagitado a lâmina...............................................24.25. Doryopteris sagittifolia.

9'. Lâmina amplamente lobada (segmentada), não apenas na base, mas também nas porções medianas e distais; deltoide a pentagonal; lobos basais, geralmente, 1-2-lobados, se inteiros, então, base da lâmina truncada a obtusa, com os lobos nunca voltados para a trás e dando aspecto sagitado a lâmina.

10. Base da lâmina com gemas.

24.13. Doryopteris patula.

10'. Base da lâmina sem gemas.

11. Margem da lamina esclerificada abaxialmente.

11'. Margem da lâmina não esclerificada.

12. Nervuras livres.

24.17. Lytoneuron Iomariaceum.

12 '. Nervuras anastomosadas.

13. Pecíolo castanho-claro, lustroso e glabro, às vezes, com tricomas esparsos na porção dis-

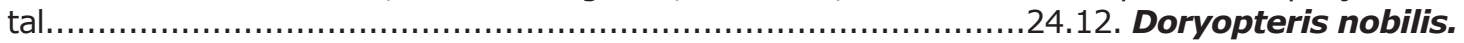

13'. Pecíolo marrom-escuro a nigrescente, opaco e pubescente....24.14. Doryopteris pentagona.

8'. Lâmina 1-pinada ou mais complexa.

14. Pseudoindúsio com nervuras; esporângios surgindo sobre a porção revoluta do tecido laminar.

15. Lâmina 1-pinada.

16. Pinas oval-deltoides; pinas com apenas dois soros, um do lado acroscópico e um basioscópico. 24.5. Adiantum macrophyllum.

16'. Pinas lanceoladas; pinas com 3 ou mais soros em ambos os lados, acroscópico e basioscópico ....

24.8. Adiantum obliquum.

15'. Lâmina 2-pinada ou mais complexa.

17. Lâmina 2-pinada.

18. Indúsio glabro; frondes com apenas um par de pinas laterais.

.24.8. Adiantum obliquum.

18'. Indúsio com tricomas; frondes com 2-3 pares de pinas laterais....24.11. Adiantum terminatum.

17'. Lâmina 3-pinada ou mais complexa.

19. Pínulas flabeladas.

20. Incisões dos últimos segmentos atingindo aproximadamente a $1 / 2$ da pínula, formando lobos arredondados. 24.10. Adiantum raddianum.

20'. Incisões dos últimos segmentos atingindo aproximadamente $2 / 3$ da pínula, formando lobos lineares. 24.4. Adiantum lorentzii. 19'. Pínulas trapeziformes ou quadrangulares.

21. Cor do peciólulo não ultrapassando para o segmento 24.6. Adiantum mathewsianum.

$21^{\prime}$. Cor do peciólulo ultrapassando para o segmento.

22. Pecíolo e raque glabros.

24.9. Adiantum pentadactylon.

22'. Pecíolo e raque pilosos, ao menos na porção distal.

23. Indúsio glabro.

23'. Indúsio com tricomas. 24.3. Adiantum curvatum. 
14'. Pseudoindúsio sem nervuras; esporângios surgindo sobre a porção regular do tecido laminar.

24. Soros interrompidos ao longo da margem. 24.1. Adiantopsis chlorophylla.

$24^{\prime}$. Soros contínuos, nunca interrompidos, ao longo da margem.

25. Lâmina 1-pinada.

26. Nervuras livres......

24.29. Pteris vittata.

$26^{\prime}$. Nervuras anastomosadas.

27. Pecíolo coberto por escamas castanho-avermelhadas em toda sua extensão...

$27^{\prime}$. Pecíolo glabro ou apenas com tricomas alvos esparsos. 24.27. Pteris schwackeana. 25'. Lâmina 1-pinado-pinatissecta ou mais complexa.

28. Nervuras anastomosadas.

29. Três ou mais aréolas entre cóstulas adjacentes.

30. Base adaxial da cóstula com aristas. 24.21. Pteris altissima.

30 '. Base adaxial da cóstula sem aristas. 24.22. Pteris angustata.

$29^{\prime}$. Duas aréolas entre cóstulas adjacentes.

31. Tecido laminar conspicuamente revestido por tricomas alvos 24.25. Pteris lechleri.

$31^{\prime}$. Tecido laminar glabro 24.23. Pteris decurrens. $28^{\prime}$. Nervuras livres.

32. Pina proximal 1-pinado-pinatífida e 1-furcada no lado basioscópico.

24.26. Pteris plumula. 32 '. Pina proximal 2-pinado-pinatífida e não furcada. 24.24. Pteris deflexa.

24.1. Adiantopsis chlorophylla (Sw.) Fée, Mém. Foug. 2: 145. 1852.

Espécie semelhante à Adiantopsis cheilanthoides R.M. Senna, porém, esta última apresenta frondes eretas e rígidas, com até $24 \mathrm{~cm}$ de comprimento, segmentos circulares, não contíguos e com a margem revoluta, portando 1-3 soros (vs. frondes de 40-80 cm de comprimento, segmentos pinatissectos a pinatífidos, contíguos e com 4-10 soros em A. chlorophylla) (Senna, 2004). Espécie terrícola, não encontrada recentemente no PETAR, no entanto, dados de coleta registram esta espécie no Estado de São Paulo, em locais abertos e expostos ao sol, como barrancos e margens de estradas (Splink, 2018).

Material selecionado examinado: BRASIL. São Paulo, Mun. Apiaí, XII.1880, J. J. Puiggari s.n. (P).

24.2. Adiantum abscissum Schrad., Gott. Gel. Anz. 87: 872. 1824.

Difere de Adiantum curvatum Kaulf. por apresentar pseudoindúsio glabro (vs. pubescentes, em ) e, de Adiantum mynsseniae Prado, por apresentar a porção distal adaxial do pecíolo e raque com escamas e tricomas (vs. escamas ausentes, em A. mynsseniae) (Winter et al., 2011). Espécie terrícola, encontrada nas trilhas, em ambientes sombreados e úmidos.

Material selecionado examinado: Mazziero \& Soller 871 (UPCB, SP, UNIP).

24.3. Adiantum curvatum Kaulf., Enum. Fil. 202. 1824.

Espécie com tricomas presentes no pseudoindúsio, sendo esta a principal característica para a sua distinção de $A$. abscissum, que, por sua vez, apresenta pseudoindúsio glabro (Winter et al.,
2011). Espécie terrícola, encontrada nas trilhas, bordas e interior da floresta, em locais sombreados e úmidos.

Material selecionado examinado: Mazziero \& Soller 826 (UPCB, SP, UNIP); Mazziero et al. 978 (UPCB); Mazziero 1073 (UPCB, SP).

24.4. Adiantum Iorentzii Hieron., Bot. Jahrb. Syst. 22: 393. 1896.

Assemelha-se à Adiantum raddianum C. Presl, da qual se separa por apresentar incisões das pínulas formando lobos lineares e estes nun$\mathrm{ca}$ atingindo a metade de seu comprimento (Winter et al., 2011). Espécie terrícola ou rupícola, crescendo às margens de riachos e cachoeiras no interior da floresta, a pleno sol.

Material selecionado examinado: Mazziero \& Soller 615 (UPCB); Mazziero \& Soller 616 (UPCB, SP); Mazziero 1036 (UPCB).

24.5. Adiantum macrophyllum Sw., Prodr. 135. 1788 .

Pode ser reconhecida pela lâmina 1-pinada, com pinas opostas e apenas um soro em cada margem, além da face abaxial glauca (Tryon \& Stolze, 1989b). Espécie terrícola, observada em locais sombreados e úmidos no interior da floresta.

Material selecionado examinado: Mazziero \& Soller 867 (UPCB, SP).

24.6. Adiantum mathewsianum Hook., Sp. Fil. 2: 35. 1851.

Apresenta lâmina subcoriácea, com segmentos terminais das penúltimas divisões assimetricamente rômbicos e pseudoindúsio oblongo a semilunar, o que a difere de Adiantum trapeziforme L. que possui lâmina membranácea, segmentos 
terminais das penúltimas divisões obovados-angulados e pseudoindúsio oblongo (Prado, 2003). Espécie rupícola, crescendo nas trilhas, em locais sombreados e secos.

Material selecionado examinado: Mazziero \& Soller 825 (UPCB, SP).

24.8. Adiantum obliquum Willd., Sp. PI. 5: 429. 1810.

Semelhante à Adiantum petiolatum Desv. e Adiantum lucidum Cav., com as quais pode formar híbridos (Prado \& Lellinger, 2002). Stolze (1981) indica que em $A$. obliquum a raque e as vênulas das pinas são pubescentes, enquanto, em $A$. petiolatum, a raque é esparsamente pubescente e as vênulas são glabras. Espécie terrícola, encontrada em áreas abertas próximas as bordas da floresta, em locais sombreados.

Material selecionado examinado: Mazziero \& Soller 874 (UPCB, SP, UNIP, NY, CAS).

24.9. Adiantum pentadactylon Langsd. \& Fisch. Ic. Fil., 22, tab. 25. 1810.

De acordo com Winter et al. (2011), é uma espécie semelhante à $A$. trapeziforme, mas apresenta pínulas não articuladas, com a cor do peciólulo ultrapassando para o tecido laminar e face abaxial não glauca (vs. pinas articuladas, com a cor do peciólulo não ultrapassando para o tecido laminar e face abaxial glauca, em A. trapeziforme). Espécie terrícola, encontrada às margens de rios, riachos e trilhas, em locais sombreados.

Material selecionado examinado: Mazziero \& Soller 894 (UPCB, SP, UNIP, NY); Mazziero 1069 (UPCB, SP).

24.10. Adiantum raddianum C. Presl, Tent. Pterid., 158. 1836.

Espécie muito semelhante à Adiantum lorentzii Hieron. (ver comentários acerca da mesma, item 24.4). Adiantum poiretii Wikstr. é outra espécie semelhante, que, no entanto, apresenta caule longo-reptante, pínulas orbiculares, sem incisões e substância cerosa amarela entre os esporângios, enquanto, $A$. raddianum apresenta caule curto-reptante, pínulas flabeliformes incisas e esporângios sem substancia cerosa (Winter et al., 2011). Espécie rupícola, encontrada nos paredões rochosos no interior da floresta, em locais úmidos e expostos ao sol.

Material selecionado examinado: Mazziero \& Soller 706 (UPCB, SP, UNIP).

24.11. Adiantum terminatum Kunze ex Miq., Verslagen Meded. Vier KI. Kon. Ned. Inst. Wetensch. Letterk. Schonne Kunsten 1842: 187. 1843.

Segundo Stolze (1981), pode ser separada das demais espécies de Adiantum que possuem lâmina 2-pinada e pínulas sésseis a subsésseis, por apresentar seguimentos conspicuamente pilosos. Espécie terrícola, encontrada no interior da floresta, em locais sombreados.

Material selecionado examinado: Mazziero \& Soller 829 (UPCB, SP, UNIP); Mazziero \& Soller 873 (UPCB, NY, CAS); Mazziero 1060 (UPCB).

24.12. Doryopteris nobilis ( $T$. Moore) C. Chr., Index Filic. 244. 1905.

Espécie semelhante à $D$. patula, porém separa-se facilmente por não apresentar gemas na base da lâmina. Espécie rupícola ou terrícola, encontrada no interior da floresta, em locais sombreados e úmidos.

Material selecionado examinado: Mazziero \& Soller 629 (UPCB, SP, UNIP).

24.13. Doryopteris patula Fée, Crypt. Vasc. Brésil 2: 30, pl. 89, f. 2, 1872.

Espécie semelhante à $D$. nobilis, separando-se, principalmente por apresentar gemas na base da lâmina. Espécie terrícola, ocorrendo em clareiras no interior da floresta, crescendo a pleno sol.

Material selecionado examinado: Mazziero \& Engels 1153 (UPCB).

24.14. Doryopteris pentagona Pic. Serm., Webbia 60(1): 231, f. 42. 2005.

Segundo Pichi-Sermolli \& Bizzarri (2005), é uma espécie que se assemelha à Doryopteris stierii Rosenst., mas esta última apresenta o pecíolo glabro e os segmentos basais primários com 3-4 segmentos secundários inteiros no lado basioscópico e lado acroscópico inteiro (vs. pecíolo piloso e segmentos basais primários com segmentos secundários acroscópicos e basioscópicos, em $D$. pentagona). Espécie terrícola ou rupícola, observada nas trilhas e no interior da floresta, em locais úmidos, sombreados ou ensolarados.

Material selecionado examinado: Mazziero \& Soller 700 (UPCB, CAS); Mazziero et al. 941 (UPCB, SP, UNIP); Mazziero et al. 980 (UPCB, NY).

24.15. Doryopteris sagittifolia (Raddi) J. Sm., J. Bot. (Hooker) 4: 163. 1841.

Espécie reconhecida por apresentar lâminas férteis e estéreis inteiras, lanceoladas, com base sagitada (Tryon, 1942). De acordo com este mesmo autor, a forma 5-lobada desta espécie pode ser confundida com $D$. nobilis, que, no entanto, apresenta todos os lobos com tamanho aproximado, enquanto, em $D$. sagittifolia, os segmentos laterais são menores que o segmento central. Espécie terrícola, encontrada no interior da floresta, em locais sombreados e úmidos. 
Material selecionado examinado: Mazziero \& Soller 902 (UPCB).

24.16. Lytoneuron crenulans (Fée) Yesilyurt, Phytotaxa 221(2): 117. 2015.

Assemelha-se à Lytoneurum itatiaiense (Fée) Yesilyurt, porém, em $L$. crenulans, as frondes férteis e estéreis são semelhantes, apesar de dimorfas (vs. frondes férteis e estéreis conspicuamente distintas, em $L$. itatiaiense), as frondes férteis também são menos divididas (vs. frondes férteis muito divididas), com segmentos terminais oblongos a lineares (vs. segmentos terminais deltoides a oblongos) e as escamas do caule longas e estreitas (vs. escamas do caule lanceoladas e atenuadas) (Tryon, 1942). Espécie rupícola ou terrícola, não encontrada recentemente na área de estudo, porém, segundo dados de coletas realizadas no Estado de São Paulo, ocorre em ambientes abertos e expostos ao sol, como barrancos ou margens de estradas (Splink, 2018).

Material selecionado examinado: BRASIL. São Paulo, Mun. Apiaí, II. 1881, J. J. Puiggari s.n. (P).

24.17. Lytoneuron Iomariaceum (Klotzsch) Yesilyurt, Phytotaxa 221(2): 117. 2015.

Espécie semelhante à Doryopteris acutiloba (Prantl) Diels., entretanto, esta última apresenta lâmina membranácea, com segmentos terminais inteiros e amplos, com ápice agudo a acuminado, por outro lado, L. Iomariaceum apresenta lâmina coriácea, com segmentos terminais estreitos, levemente crenulados, com ápice arredondado (Tryon, 1942). Espécie terrícola, não registrada recentemente no PETAR, mas ocorre em locais abertos e expostos ao sol, muitas vezes em solo encharcado, de acordo com os dados de coletas da espécie, para o Estado de São Paulo, disponíveis no Splink (2018).

Material selecionado examinado: BRASIL. São Paulo, Mun. Apiaí, XIII.1888, J. J. Puiggari s.n. (P).

24.18. Pityrogramma calomelanos (L.) Link, Handbuch 3: 20. 1833.

De acordo com Tryon \& Stolze (1989b), Pityrogramma ebenea (L.) Proctor é a espécie mais semelhante, no entanto, em $P$. calomelanos as pinas são equilaterais com pínulas ascendentes em relação à raque, enquanto, $P$. ebenea apresenta pinas inequilaterais e pínulas patentes. Espécie terrícola, encontrada às margens das estradas, em locais úmidos e exposta ao sol.

Material selecionado examinado: Mazziero \& Soller 619 (UPCB, SP, UNIP).

24.19. Pityrogramma trifoliata (L.) R.M. Tryon, Contr. Gray Herb. 189: 68. 1962.
Segundo Tryon \& Stolze (1989b), esta espécie apresenta base do pecíolo com feixes vasculares formando um " $C$ ", além das pinas inteiras a 3-folioladas. Espécie terrícola, crescendo às margens de estradas, em locais ensolarados e úmidos.

Material selecionado examinado: Mazziero \& Soller 699 (UPCB, SP).

24.20. Polytaenium lineatum (Sw.) J. Sm., J. Bot. (Hooker) 4: 68. 1841.

Polytaenium feei (W. Schaffn. ex Fée) Maxon é uma espécie semelhante à $P$. lineatum, mas apresenta soros irregulares, superficiais ou pouco imersos no tecido laminar, além da ausência das aletas marginais dos sulcos (em $P$. lineatum, os soros são perfeitamente lineares, dispostos em sulcos profundos e com uma ala marginal) (Mickel \& Smith, 2004; Nonato \& Windisch, 2004). Espécie epífita, observada no interior da floresta, em locais sombreados e úmidos.

Material selecionado examinado: Mazziero 1030. (UPCB).

24.21. Pteris altissima Poir., Encycl. 5: 722. 1804.

Pteris propinqua J. Agardh é uma espécie semelhante à $P$. altissima, mas difere por apresentar entre cóstulas adjacentes uma aréola alongada, enquanto, $P$. altissima possui duas a três aréolas (Prado \& Windisch, 2000). Espécie terrícola, encontrada às margens de córregos no interior da floresta, em locais sombreados.

Material selecionado examinado: Mazziero \& Soller 671 (UPCB, SP, UNIP).

24.22. Pteris angustata (Fée) C.V. Morton, Contr. U.S. Natl. Herb. 38: 72. 1967.

Espécie reconhecida pela presença, entre cóstulas adjacentes, de 4-8 aréolas, bem como pelo sinus amplo (Prado \& Windisch, 2000). Espécie terrícola, encontrada no interior da floresta, em locais úmidos e sombreados.

Material selecionado examinado: Mazziero \& Albiero Jr. 1089 (UPCB).

24.23. Pteris decurrens C. Presl, Delic. Prag. 1: 183.1822.

Segundo Prado \& Windisch (2000), Pteris lechleri Mett. e Pteris biaurita L. podem ser confundidas com $P$. decurrens, contudo, a primeira difere de $P$. decurrens por apresentar indumento seríceo e a segunda por apresentar cóstulas adjacentes com uma aréola. Espécie terrícola, crescendo no interior da floresta, em locais sombreados e úmidos.

Material selecionado examinado: Mazziero et al. 948 (UPCB, SP, UNIP, NY); Mazziero \& Albiero Jr. 1090 (UPCB, RB). 
24.24. Pteris deflexa Link, hort. Berol. 2: 30. 1833.

Pteris deflexa pode ser confundida $\operatorname{com} P$. altissima, porém, $P$. deflexa tem nervuras livres, e $P$. altissima apresenta venação areolada, com duas a três aréolas entre as costas adjacentes (Prado \& Windisch, 2000). Espécie terrícola, observa em trilhas e estradas que cortam a floresta, em locais sombreados e úmidos.

Material selecionado examinado: Mazziero \& Soller 880 (UPCB, SP); Mazziero et al. 976 (UPCB, UNIP); Mazziero 1045 (UPCB, SP, NY, CAS).

24.25. Pteris lechleri Mett., Fil. Lechl. 2: 13. 1859.

Espécie semelhante à $P$. decurrens e Pteris biaurita L., mas separa-se facilmente por apresentar indumento seríceo, característica ausente nas outras duas (Prado \& Windisch, 2000). Espécie terrícola, crescendo no interior da floresta, em locais sombreados e úmidos.

Material selecionado examinado: Mazziero \& Albiero Jr. 1115 (UPCB, SP).

24.26. Pteris plumula Desv., Mém. Soc. Linn. Paris 6: 297. 1827.

De acordo com Prado \& Windisch (2000), esta espécie assemelha-se à Pteris biaurita L. e Pteris pungens Willd., contudo, a primeira apresenta as nervuras parcialmente anastomosadas e a segunda tem espinhos no pecíolo e raque, características ausentes em $P$. plumula. Erva terrícola, observada no interior da floresta, em locais úmidos e sombreados.

Material selecionado examinado: Mazziero \& Soller 623 (UPCB, SP, UNIP).

24.27. Pteris schwackeana Christ, Pl. Nov. Min. 26. 1900.

Esta espécie se assemelha à Pteris splendens Kaulf., no entanto, a última apresenta lâmina subcoriácea, pecíolo e raque glabros, com escamas concentradas apenas no caule e na base do pecíolo (vs. lâmina membranácea e escamas dispersas por todo o pecíolo) (Prado \& Windisch, 2000). Espécie terrícola, observada nas trilhas e no interior da floresta, em locais sombreados e úmidos.

Material selecionado examinado: Mazziero \& Soller 861 (UPCB, SP, UNIP).

24.28. Pteris splendens Kaulf., Enum. Filic. 186. 1824.

Semelhante à $P$. schwackeana, da qual se separa principalmente pelas características propostas na chave de identificação e nos comentários acerca da espécie anterior (item 24.27). Espécie terrícola, encontrada no interior da floresta, em locais úmidos e sombreados.
Material selecionado examinado: Mazziero \& Albiero Jr. 1098 (UPCB, SP, UNIP, NY).

24. 29. Pteris vittata L., Sp. PI. 2: 1074. 1753.

Separa-se de outras espécies brasileiras com lâmina 1-pinada, pela presença de pinas articuladas à raque e nervuras livres (Prado \& Windisch, 2000). Espécie rupícola, encontrada em barrancos às margens de estradas, em pontos ensolarados.

Material selecionado examinado: Mazziero \& Soller 698 (UPCB).

24.30. Radiovittaria stipitata (Kunze) E.H. Crane, Syst. Bot. 22(3): 514. 1997 (1998).

Separada de Radiovittaria gardneriana (Fée) E.H. Crane, a única outra espécie do gênero no Brasil, pela base das escamas caulinares com 1-2 células de largura, lineares e pela base do pecíolo cilíndrico (vs. base das escamas caulinares com 3-8 células, lanceoladas, e base do pecíolo achatado, em R. gardneriana) (Nonato \& Windisch, 2004). Espécie epífita, encontrada no interior da floresta ou em trilhas, em locais sombreados e úmidos.

Material selecionado examinado: Mazziero \& Soller 590 (UPCB, NY, CAS); Mazziero \& Soller 837 (UPCB, SP, UNIP); Mazziero \& Soller 899 (UPCB); Mazziero et al. 965 (UPCB); Mazziero \& Soller 698 (UPCB).

24.31. Tryonia myriophylla Schuettp., J. Prado \& A.T. Cochran, Phytokeys 35: 40. 2014.

Pode ser separada da única outra espécie do gênero no Estado de São Paulo, Tryonia areniticola (Schwartsb. \& Labiak) Schuettp., J. Prado \& A.T. Cochran, pela raque desprovida de tricomas glandulares e por possuir frondes de até $1 \mathrm{~m}$ de comprimento (vs. tricomas glandulares presentes e frondes de até $15 \mathrm{~cm}$, em $T$. areniticola) (Schwartsburd \& Labiak, 2008). Espécie terrícola, não encontrada em campo no presente estudo, mas dados de sua coleta para o Estado de São Paulo indicam sua ocorrência em locais abertos e expostos ao sol, como barrancos às margens de estradas (Splink, 2018).

Material selecionado examinado: BRASIL. São Paulo, Mun. Apiaí, s.d., J. J. Puiggari 2393 (P).

24.32. Vittaria graminifolia Kaulf., Enum. Filic. 192. 1824.

Vittaria scabrida Klotzsch ex Fée é uma espécie semelhante, distinguindo-se pelas frondes com 10-12 cm de comprimento e paráfises cuculiformes castanho-claras (vs. $10-50 \mathrm{~cm}$ e paráfises claviformes avermelhadas, em $V$. graminifolia) (Labiak \& Prado, 1998). Espécie epífita, é encontrada em locais sombreados e úmidos, no interior da floresta. 
Material selecionado examinado: Mazziero et al. 942 (UPCB, SP, UNIP, NY); Mazziero \& Albiero Jr. 1137 (UPCB, RB, CAS).

24.33. Vittaria lineata (L.) Sm., Mém. Acad. Roy. Soc. (Turin) 5 (1790-1791): 421, pl. 9, f. 5. 1793.

No Estado de São Paulo também ocorre Vittaria graminifolia (Prado, 2015b), sendo estas espécies separadas, principalmente, pelas características indicadas na chave de identificação. Espécie epífita, encontrada nas trilha, às margens de córregos e no interior da floresta, em locais sombreados e úmidos.

Material selecionado examinado: Mazziero \& Soller 638 (UPCB); Mazziero \& Soller 832 (UPCB, $\mathrm{SP})$.

\section{SACCOLOMATACEAE}

1. Lâmina 1-pinada.

25.2. Saccoloma elegans.

1'. Lâmina 2-pinado-pinatífida. 25.1. Saccoloma brasiliense.

25.1. Saccoloma brasiliense (C. Presl) Mett., Ann. Sci. Nat., Bot., sér. 4, 15: 80. 1861.

Esta espécie se separa de Saccoloma inaequale (Kunze) Mett., por apresentar soros surgindo nos dentes dos segmentos, enquanto que, em S. inaequale, os soros surgem nos sinus (Schwartsburd, 2015). Espécie terrícola, encontrada no interior da floresta, em locais sombreados e úmidos.

Material selecionado examinado: Mazziero \& Albiero Jr. 1135 (UPCB, SP, UNIP).

25.2. Saccoloma elegans Kaulf., Berlin. Jahrb. Pharm. Verbundenen Wiss. 21: 51. 1820.

Segundo Rojas-Alvarado (2010), S. elegans separa-se das espécies neotropicais do gênero, pela lâmina 1-pinada (vs. 2-4-pinadas nas outras espécies). Espécie terrícola, encontrada em triIhas e no interior da floresta, em locais sombreados e úmidos.

Material selecionado examinado: Mazziero \& Soller 811 (UPCB, CAS); 14.II-2012, Mazziero et al. 926 (UPCB, SP, UNIP, NY).

\section{SALVINIACEAE}

26.1. Azolla filiculoides Lam., Encycl. 1(1): 343. 1783
Separa-se de Azolla cristata Kaulf., única outra espécie do gênero encontrada no Brasil, segundo Salino \& Almeida (2015), pela presença de ramificação pinada, com 2-6 cm de comprimento e folhas de $1 \mathrm{~mm}$ de comprimento, enquanto, A. cristata é, geralmente, menor que $2 \mathrm{~cm}$ de comprimento, dicotomicamente ramificada e apresenta folhas menores que $1 \mathrm{~mm}$ de comprimento (Tryon \& Stolze, 1994). Espécie aquática flutuante, encontrada em lagos e lagoas (Salino \& Almeida, 2015; Kessler \& Smith, 2017).

Material selecionado examinado: BRASIL. São Paulo, Mun. Apiaí, s.d., J. J. Puiggari s.n. (RB).

\section{SCHIZAEACEAE}

27.1. Schizaea elegans (Vahl) Sw., J. Bot. (Schrader) 1800(2): 103. 1801.

No Estado de São Paulo também ocorre Schizaea fluminensis Miers ex J.W. Sturm, na qual a lâmina apresenta até $1 \mathrm{~cm}$ de largura, com contorno linear (vs. lâmina com 15-35 cm de largura e flabeliforme, em S. elegans) (Silva et al., 2015). Espécie terrícola, observada no interior da floresta, em locais sombreados.

Material selecionado examinado: Mazziero et al. 961 (UPCB, SP, UNIP, NY).

\section{SELAGINELLACEAE}

1. Rizóforos dorsais; base do microfilo axilar com duas aurículas longas.......28.6. Selaginella sulcata.

$1^{\prime}$. Rizóforos ventrais; base do microfilo axilar sem aurículas.

2. Microfilos adpressos ao caule... 28.4. Selaginella microphylla.

2'. Microfilos não adpressos ao caule.

3. Microfilos com margem ciliada.

3'. Microfilos com margem inteira ou levemente denteada.

4. Estróbilos complanados; esporofilos dimorfos; microfilos laterais ovais, patentes................................................................................

4'. Estróbilos quadrangulares; esporofilos monomorfos; microfilos laterais oval-lanceolados, ascendentes.

5. Caule ereto; microfilos laterais ascendentes e lanceolados....28.1. Selaginella decomposita.

5 '. Caule prostrado; microfilos laterais patentes e oblongos............28.2. Selaginella flexuosa. 
28.1. Selaginella decomposita Spring, Fl. Bras. 1(2): 123. 1840.

Separa-se das demais espécie encontradas no Estado de São Paulo, por apresentar caule ereto, o ápice dos microfilos dorsais aristado e microfilos laterais ascendentes, espaçados e com margens denticuladas (Hirai \& Prado, 2000). Espécie terrícola, encontrada em locais úmidos e sombreados ou a pleno sol, próxima a corpos d'água ou barrancos (Hirai \& Prado, 2000; Hirai, 2015).

Material selecionado examinado: BRASIL. São Paulo, Mun. Apiaí, s.d., J. J. Puiggari s.n. (RB).

28.2. Selaginella flexuosa Spring, Flora 21: 197. 1838.

Distingue-se das demais espécies de Selaginella do Estado de São Paulo, por seus microfilos apresentarem textura rugosa na face adaxial ( $\mathrm{Hi}-$ rai \& Prado, 2000). Espécie terrícola, habitando o interior da floresta, trilhas e às margens de riachos, em locais úmidos e sombreados.

Material selecionado examinado: Mazziero \& Soller 576 (UPCB); Mazziero \& Soller 877 (UPCB); Mazziero \& Soller 889 (UPCB); Mazziero et al. 929 (UPCB, SP, UNIP, NY); Mazziero 1014 (UPCB, CAS); Mazziero, 1071 (UPCB).

28.3. Selaginella macrostachya (Spring) Spring, Bull. Acad. Roy. Sci. Brux. 10(1): 144. 1843.

Pode ser reconhecida dentre as demais espécies do gênero com microfilos ciliados, encontradas no Estado de São Paulo, pela base cordada dos microfilos axilares e microfilos laterais de contorno oval (Hirai \& Prado, 2000). Espécie terrícola, observada no interior da floresta e às margens de córregos, em locais sombreados.

Material selecionado examinado: Mazziero \& Soller 890 (UPCB); Mazziero \& Soller 906 (UPCB, NY); Mazziero \& Soller 907 (UPCB, SP, UNIP); Mazziero 1072 (UPCB, CAS).
28.4. Selaginella microphylla (Kunth) Spring, Bull. Acad. Roy. Sci. Brux. 10(1): 234. 1843.

Espécie caracterizada pelos microfilos laterais adpressos ao caule e por todos os microfilos apresentarem às margens longamente ciliadas (Hirai \& Prado, 2000). Espécie rupícola ou terrícola, ocorrendo em ambientes sombreados e úmidos, próximos a córregos e quedas d'água ou em afloramentos rochosos (Hirai \& Prado, 2000; Hirai, 2015).

Material selecionado examinado: BRASIL. São Paulo, Mun. Apiaí, s.d., J. J. Puiggari 271 (P).

28.5. Selaginella muscosa Spring, Fl. Bras. 1(2): 120. 1840.

Difere de Selaginella tenuissima Fée, pela presença de microfilos axilares ovais, desprovidos de dentes longos e base externa arredondada (vs. microfilos axilares oblongos, com a base truncada e a margem com dentes longos, em $S$. tenuissima) (Hirai \& Prado, 2000). Espécie terrícola ou rupícola, que cresce às margens dos córregos, exposta ao sol.

Material selecionado examinado: Mazziero \& Soller 875 (UPCB, SP UNIP); Mazziero \& Soller 892 (UPCB); Mazziero \& Soller 910 (UPCB).

28.6. Selaginella sulcata (Desv. ex Poir.) Spring, Flora 20(2): 126. 1837.

Segundo Alston et al. (1981), esta espécie distingue-se das demais, que também possuem caule prostrado e articulado, por apresentar microfilos axilares com duas aurículas longas, retas e não ciliadas. Espécie terrícola, encontrada em barrancos na beira das estradas e no interior da floresta, em locais sombreados e úmidos.

Material selecionado examinado: Mazziero \& Soller 824 (UPCB, SP, UNIP, NY); Mazziero \& Soller 903 (UPCB); Mazziero 1015 (UPCB, CAS).

\section{TECTARIACEAE}

1. Gemas presentes na base das pinas apicais; tricomas esparsos presente apenas nas nervuras secundárias e raque........................................................................ Tectaria incisa. 1'. Gemas ausentes na base das pinas apicais; tecido laminar, nervuras secundárias e raque densamente cobertos por tricomas.... 29.2. Tectaria pilosa.

29.1. Tectaria incisa Cav., Descr. PI. 249. 1801.

De acordo com Moran (1995b), esta espécie se assemelha à Tectaria heracleifolia (Willd.) Underw., mas difere por apresentar indúsio lateralmente fixado, 3-10 pares de pinas laterais, com base cuneada a decurrente (vs. indúsio peltado, 0-2 a raro 4 pares de pinas laterais e base das pinas cordadas, em $T$. heracleifolia). Espécie ter- rícola, observada nas trilhas e no interior da floresta, em locais sombreados e úmidos.

Material selecionado examinado: Mazziero et al. 931 (UPCB, SP, UNIP, NY).

29.2. Tectaria pilosa (Fée) R. C. Moran, Novon 2(2): 138. 1992. 
Tectaria pilosa difere de $T$. incisa, principalmente por apresentar lâmina pubescente e 1-4 pares de pinas, por sua vez, $T$. incisa possui lâmina glabra a glabrescente e 4-12 pares de pinas (Moran, 1995b). Espécie terrícola, encontrada no interior da floresta e em trilhas, em locais sombreados e úmidos.

Material selecionado examinado: Mazziero \& Soller 676.

\section{THELYPTERIDACEAE}

1. Lâmina 2-3-pinado-pinatissecta.

1'. Lâmina 1-pinada a 1-pinado-pinatissecta.

2. Tricomas estrelados e/ou furcados presente ao menos na raque.

3. Ápice da lâmina conforme; pinas inteiras ou levemente pinatífidas, com incisões não ultrapassando $1 / 4$ da distância entre a costa e a margem...................................30.20. Goniopetris vivipara.

3'. Ápice da lâmina pinatífido; pinas nitidamente pinatífidas, com incisões iguais ou maiores que a 1/2 da distância entre a costa e a margem.

4. Tecido laminar entre as nervuras glabro. 30.19. Goniopteris scabra. 4'. Tecido laminar entre as nervuras pubescente. 30.18. Goniopteris lugubris.

2 '. Tricomas estrelados e/ou furcados ausentes.

5. Lâmina 1-pinada; venação meniscióide.

6. Margem das pinas serreadas; nervuras primárias, secundárias e tecido laminar entre as vênulas com tricomas setosos.................................................... 30.23. Meniscium serratum. 6'. Margem das pinas crenadas a inteiras; nervuras primárias, secundárias e tecido laminar com tricomas glandulares.................................................30.22. Meniscium maxonianum.

5'. Lâmina 1-pinado-pinatífida a 1-pinado-pinatissecta; nervuras livres ou, às vezes, nervuras de segmentos adjacentes se unindo, formando uma aréola próxima à costa.

7. Base da lâmina com 2-20 pares de pinas reduzidas, as proximais auriculiformes.

8. Soros proximais lineares ou elípticos.

9. Pinas medianas sésseis, com base truncada; gemas presentes na axila das pinas distais; aeróforos presentes............................................30.1. Amauropelta amambayensis. 9'. Pinas medianas pecioluladas, com base cuneada; gemas ausentes; aeróforos ausentes. 30.12. Amauropelta saxicola.

8'. Soros proximais arredondados a reniformes.

10. Cápsula dos esporângios com tricomas setosos 30.4. Amauropelta concinna. 10'. Cápsula dos esporângios glabra.

11. Tricomas uncinados ausentes.

12. Escamas costais e aeróforos ausentes.

$12^{\prime}$. Escamas costais e aeróforos presentes.

13. Soros submarginais, cobertos pela margem revoluta da lâmina.....................................................30.3. Amauropelta cheilanthoides.

13'. Soros medianos, não cobertos pela margem da lâmina

30.8. Amauropelta pachyrhachis.

11 '. Tricomas uncinados presentes, ao menos, no tecido laminar.

14. Raque, costa, cóstula e tecido laminar com tricomas uncinados..........................................................30.10. Amauropelta regnelliana.

$14^{\prime}$. Apenas o tecido laminar com tricomas uncinados.

15. Caule curto a longo-reptante.

16. Base da lâmina abruptamente reduzida, com 2 pares de pinas menores.............................................................. A 16'. Base da lâmina gradualmente reduzida, com 3-11 pares de pinas menores.

17. Pecíolo, raque e costa abaxial com tricomas pluricelulares......................................................30.11. Amauropelta rivularioides.

17'. Pecíolo, raque e costa abaxial com tricomas unicelulares setiformes............................................................ Amauropelta ireneae.

15'. Caule ereto a decumbente.

18. Gemas presentes; tricomas pluricelulares e tortuosos presentes na face abaxial da raque e costa...............................................30.2. Amauropelta araucariensis.

18'. Gemas ausentes; tricomas unicelulares e setiformes presentes na face abaxial da raque e costa..............................................30.6. Amauropelta oligocarpa.

7'. Base da lâmina pouco ou não reduzida, às vezes, 1-2 pares de pinas levemente menores.

19. Segmentos adjacentes com nervuras basais alcançando a margem acima do sinus.

20. Caule ereto; aeróforos presentes.

30.24. Steiropteris decussata.

20'. Caule curto-reptante; aeróforos ausentes 30.25. Steiropteris hatschbachii.

Rev. Biol. Neotrop. / J. Neotrop. Biol., Goiânia, v. 15, n. 1, p. 22-72, jan.-jun. 2018 
19'. Segmentos adjacentes com nervuras basais unindo-se à uma nervura excurrente ou alcançando diretamente o sinus.

21. Caule ereto; escamas da base do pecíolo alvas a castanho-claras; nervuras basais de segmentos adjacentes unindo-se ao sinus................................30.16. Christella patens.

21'. Caule curto a longo-reptante; escamas da base do pecíolo castanho-escuras; nervuras basais de segmentos adjacentes unindo-se em uma nervura excurrente.

22. Caule longo-reptante; lâmina de consistência coriácea; face abaxial da costa com escamas.

30.17. Cyclosorus interruptus.

22'. Caule curto-reptante; lâmina de consistência cartácea; face abaxial da costa sem escamas.

23. União das nervuras basais de segmentos adjacentes formando um ângulo agudo; superfície adaxial do tecido laminar entre as nervuras estrigoso......30.13. Christella conspersa.

23'. União das nervuras basais de segmentos adjacentes formando um ângulo reto; superfície adaxial do tecido laminar entre as nervuras não estrigoso.

24. Pecíolo castanho-claro; tricomas da costa variando entre 0,3-0,5 mm de tamanho............................................................. Cho.15. Chistella hispidula.

24'. Pecíolo estramíneo a castanho-púrpura; tricomas da costa uniformes, com 0,2 mm de tamanho.

30.14. Christella dentata.

30.1. Amauropelta amambayensis (Ponce) Salino \& T. E. Almeida, Phytokeys 57: 16. 2015.

Semelhante à $A$. raddii e $A$. regnelliana, mas difere pelos soros desprovidos de indúsio, sendo os proximais elípticos, bem como pela presença de tricomas uncinados nas escamas, pecíolo, raque e na face abaxial da costa, cóstula e tecido laminar (Salino \& Semir, 2004a). Espécie terrícola, encontrada em trilhas, barrancos e no interior da floresta, em locais sombreados e úmidos.

Material selecionado examinado: Mazziero \& Soller 614 (UPCB); Mazziero \& Soller 632 (UPCB); Mazziero \& Soller 633 (UPCB); Mazziero \& Soller 677 (UPCB, SP, UNIP, NY, CAS); Mazziero 998 (UPCB).

30.2. Amauropelta araucariensis (Ponce) Salino \& T. E. Almeida, Phytokeys 57: 16. 2015.

Assemelha-se à Amauropelta retusa (Sw.) Pic. Serm., que apresenta 14-22 pares de pinas e 3-6 nervuras por segmento, enquanto, $A$. araucariensis possui 32-36 pares de pinas, 9-11 nervuras por segmento e gema na porção distal da lâmina (Salino \& Semir, 2004a). Espécie terrícola, observada em barrancos às margens de estradas, em locais úmidos e sombreados.

Material selecionado examinado: Mazziero 1009 (UPCB, NY, CAS); Mazziero 1018 (UPCB, $\mathrm{SP})$.

30.3. Amauropelta cheilanthoides (Kunze) A. Löve \& D. Löve, Taxon 26(2-3): 325. 1977.

Esta espécie possui indúsio com a superfície glabra, sendo distinta de Amauropelta tenerrima (Fée) Salino \& T. E. Almeida, a qual apresenta a superfície do indúsio com tricomas setiformes (Salino \& Semir, 2004a). Espécie terrícola ou rupícola, encontrada em barrancos nas estradas ou na borda da floresta, em locais úmidos e sombreados ou exposta ao sol.
Material selecionado examinado: Mazziero \& Soller 680 (UPCB, SP, CAS); Mazziero 997 (UPCB, CAS).

30.4. Amauropelta concinna (Willd.) Pic. Serm., Webbia 31(1): 351. 1977.

Semelhante à Amauropelta stierii (Rosenst.) Salino \& T. E. Almeida, entretanto, A. stierii apresenta a base da lâmina com 2-5 pares de pinas reduzidas, segmentos com 3-7 pares de nervuras e face abaxial do tecido laminar com tricomas glandulares (vs. 7-8 pares de pinas reduzidas, 8-10 pares de nervuras e ausência de tricomas glandulares, em A. concinna) (Salino \& Semir, 2004a). Espécie terrícola, encontrada nas trilhas, em locais sombreados e úmidos.

Material selecionado examinado: Mazziero 1011 (UPCB, SP, UNIP, CAS).

30.5. Amauropelta ireneae (Brade) Salino \& T. E. Almeida, Phytokeys 57: 24. 2015.

Espécie afim de $A$. oligocarpa, $A$. raddii e $A$. regnelliana, mas difere por apresentar 7-11 pares de pinas basais reduzidas, enquanto as demais possuem no máximo cinco pares (Salino \& Semir, 2004a). Espécie terrícola, observada na borda da floresta, em locais sombreados.

Material selecionado examinado: Mazziero \& Albiero Jr. 1124 (UPCB, SP, CAS).

30.6. Amauropelta oligocarpa (Humb. \& Bonpl. ex Willd.) Pic. Serm., Webbia 31(1): 251. 1977.

Amauropelta ptarmiciformis (C. Chr. \& Rosenst. ex Rosenst.) Salino \& T. E. Almeida assemelha-se à esta espécie, mas $A$. ptarmiciformis apresenta tricomas glandulares no tecido laminar abaxial e no indúsio e não apresenta tricomas uncinados, já em $A$. oligocarpa, os tricomas glandulares são ausentes e os uncinados presentes 
(Salino \& Semir, 2004a). Espécie terrícola, encontrada no interior da floresta em nas trilhas, em locais sombreados e úmidos.

Material selecionado examinado: Mazziero 1016 (UPCB, CAS); Mazziero \& Albiero Jr. 1082 (UPCB).

30.7. Amauropelta opposita (Vahl) Pic. Serm., Webbia 31(1): 251. 1977.

Espécie desprovida de aeróforos e escamas costais, mas com tricomas setiformes no tecido laminar, o que a difere de $A$. pachyrhachis (Kunze ex Mett.) Salino \& T. E. Almeida, que apresenta aeróforos e escamas costais, além disso, os tricomas setiformes estão ausentes no tecido laminar (Salino \& Semir, 2004a; Ponce 2007). Espécie terrícola, crescendo na borda da floresta e em barrancos nas estradas, em locais ensolarados.

Material selecionado examinado: Mazziero \& Soller 620 (UPCB, SP, CAS).

30.8. Amauropelta pachyrhachis (Kunze ex Mett.) Salino \& T. E. Almeida, Phytokeys 57: 28. 2015.

Trata-se de uma espécie semelhante à $A$. opposita e as diferenças podem ser vistas nos comentários desta (item 30.7). Espécie terrícola, habitando barrancos às margens de estradas e trilhas, em locais sombreados e úmidos.

Material selecionado examinado: Mazziero \& Soller 683 (UPCB, UNIP, CAS); Mazziero \& Soller 817 (UPCB, SP, CAS).

30.9. Amauropelta raddii (Rosenst.) Salino \& T. E. Almeida, Phytokeys 57: 31. 2015.

Semelhante à $A$. oligocarpa, porém, esta espécie apresenta 4-5 pares de pinas reduzidas na base da lâmina, enquanto, em $A$. raddii, são encontrados 1-2 pares de pinas reduzidas (Salino \& Semir, 2004a). Espécie terrícola, encontrada em barrancos às margens das estradas e nas trilhas, em locais sombreados e úmidos.

Material selecionado examinado: Mazziero \& Soller 682 (UPCB); Mazziero \& Soller 818 (UPCB, SP, UNIP); Mazziero \& Soller 848 (UPCB, CAS); Mazziero \& Soller 872 (UPCB, CAS).

30.10. Amauropelta regnelliana (C. Chr.) Salino \& T. E. Almeida, Phytokeys 57: 31. 2015.

Esta espécie pode ser reconhecida, das demais do Estado de São Paulo, por apresentar a face abaxial com indumento de tricomas uncinados presentes na costa, cóstula, tecido laminar, nervuras e indúsio, podendo também ocorrer no receptáculo (Salino \& Semir, 2004a). Espécie terrícola, encontrada no interior da floresta, em locais sombreados.

Material selecionado examinado: Mazziero \& Albiero Jr. 1122 (UPCB, SP, CAS).
30.11. Amauropelta rivularioides (Fée) Salino \& T. E. Almeida, Phytokeys 57: 32. 2015.

De acordo com Salino \& Semir (2004a), assemelha-se à Amauropelta eriosora (Fée) Salino \& T. E. Almeida, porém, $A$. rivularioides apresenta tricomas uncinados na face abaxial e, frequentemente, as nervuras proximais são furcadas, enquanto, $A$. eriosora não apresenta tricomas uncinados na face abaxial e as nervuras proximais são sempre simples. Espécie terrícola, observada na borda da floresta, em ambiente brejoso, exposta ao sol.

Material selecionado examinado: Mazziero 1008 (UPCB, SP); Mazziero \& Albiero Jr. 1112 (UPCB).

30.12. Amauropelta saxicola (Sw.) Salino \& T. E. Almeida, Phytokeys 57: 33. 2015.

Distingue-se de $A$. amambayensis pelas características propostas na chave. Espécie rupícola, encontrada às margens de córregos, em locais sombreados.

Material selecionado examinado: Mazziero \& Soller 835 (UPCB, UNIP, CAS); Mazziero \& Soller 869 (UPCB, SP, CAS); Mazziero 1012 (UPCB, CAS).

30.13. Christella conspersa (Schrad.) Á. Löve \& D. Löve, Taxon 26(2-3): 326. 1977.

De acordo com Salino \& Semir (2002), trata-se de uma espécie relacionada com $C$. dentata (Forssk.) Brownsey \& Jermy e C. hispidula (Decne.) Holttum, mas pode ser reconhecida pela presença de indumento mais denso na raque, costa abaxial e indúsio, pelo tecido laminar adaxial estrigoso e pelo indúsio com tricomas glandulares e setiformes. Espécie terrícola, encontrada em ambientes abertos próximos a borda da floresta, úmidos e ensolarados.

Material selecionado examinado: Mazziero 1001 (UPCB).

30.14. Christella dentata (Forssk.) Brownsey \& Jermy, Brit. Fern. Gaz. 10(6): 338. 1973.

Separa-se de $C$. hispidula por esta apresentar tricomas da costa de tamanhos entre 3-5 mm de comprimento, enquanto que, em $C$. dentata, esses tricomas são uniformes, com $2 \mathrm{~mm}$ de comprimento (Salino \& Semir, 2002). Espécie terrícola, habitando trilhas ou às margens de estradas, em locais úmidos e sombreados.

Material selecionado examinado: Mazziero \& Soller 630 (UPCB, CAS); Mazziero \& Soller 834 (UPCB); Mazziero 995 (UPCB, SP); Mazziero 1017 (UPCB).

30.15. Christella hispidula (Decne.) Holttum, Kew Bull. 31(2): 312. 1976. 
Christella hispidula é semelhante à C. conspersa e C. dentata, e a distinção entre estas espécies já fora apresentada anteriormente (itens 30.13 e 30.14$)$. Espécie rupícola, encontrada às margens de córregos, em locais sombreados.

Material selecionado examinado: Mazziero \& Soller 834 (UPCB).

30.16. Christella patens (Sw.) Holttum, Webbia 30(1): 193. 1976.

Pode ser separada das espécies do gênero encontradas no Estado de São Paulo, pela presença de caule ereto portando escamas glabras (Salino \& Semir, 2002). Espécie terrícola, encontrada em barrancos às margens das estradas, clareiras e borda da floresta, em locais úmidos e sombreados ou secos e a pleno sol.

Material selecionado examinado: Mazziero \& Soller 678 (UPCB, SP, CAS); Mazziero \& Soller 679 (UPCB, UNIP, CAS); Mazziero 1002 (UPCB, NY, CAS).

30.17. Cyclosorus interruptus (Willd.) H. Itô, Bot. Mag. (Tokyo) 51(608): 714. 1937.

Espécie facilmente reconhecida por apresentar caule longo-reptante, negro, nervuras de segmentos adjacentes unindo-se em uma nervura excurrente, pinas basais pecioluladas e escamas costais evidentes (Salino \& Semir, 2002). Espécie terrícola, encontrada em locais brejosos na borda da floresta, a pleno sol.

Material selecionado examinado: Mazziero 1062 (UPCB, SP, UNIP).

30.18. Goniopteris lugubris (Mett.) Brade, Bradea 1(22): 216. 1972.

Goniopteris beckeriana (F.B. Matos, A. R. Sm \& Labiak) Salino \& T. E. Almeida é uma espécie semelhante, mas difere por apresentar caule ereto e gemas (vs. caule curto-reptante e gemas nem sempre presentes, em G. lugubris) (Matos et al., 2010). Espécie terrícola, encontrada no interior da floresta, em locais sombreados.

Material selecionado examinado: Mazziero et al. 954 (UPCB, CAS).

30.19. Goniopteris scabra (C. Presl) Brade, Bradea 1(22): 217. 1972.

Goniopteris semirii (Salino \& Melo) Salino \& T. E. Almeida possui caule ereto, face abaxial da costa, tecido laminar, nervuras e indúsio com tricomas glandulares e lâmina sempre desprovida de gemas, enquanto, em G. scabra, o caule é curto-reptante, não ocorrem tricomas glandulares e possui gemas nas pinas distais (Salino \& Melo, 2000). Espécie terrícola ou rupícola, observada no interior da floresta, em locais sombreados e úmidos.
Material selecionado examinado: Mazziero \& Soller 556 (UPCB); Mazziero \& Soller 558 (UPCB, CAS); Mazziero \& Soller 570 (UPCB, SP); Mazziero \& Soller 593 (UPCB, CAS, UNIP).

30.20. Goniopteris vivipara (Raddi) Brade, Bradea 1(22): 217. 1972.

Semelhante à Goniopteris iguapensis (C. Chr.) Brade, porém, apresenta maior número de pares de pinas, reduzidas na direção do ápice da lâmina e esporângios glabros, enquanto, G. vivipara possui menor número de pares de pinas, lâmina com ápice conforme e tricomas no pedicelo dos esporângios (Salino, 2002). Espécie terrícola, encontrada no interior da floresta, trilhas e em barrancos nas estradas, em locais sombreados e úmidos.

Material selecionado examinado: Mazziero \& Soller 868 (UPCB, SP, NY, CAS); Mazziero et al. 928 (UPCB, SP, UNIP); Mazziero et al. 958 (UPCB, CAS); Mazziero 1064 (UPCB, SP).

30.21. Macrothelypteris torresiana (Gaudich.) Ching, Acta Phytotax. Sin. 8: 310. 1963.

Distingue-se das demais espécies de Thelypteridaceae do Estado de São Paulo, pela lâmina 2-3-pinado-pinatífida (Salino \& Semir, 2002). Espécie terrícola, encontrada nas bordas da floresta, em locais úmidos e ensolarados.

Material selecionado examinado: Mazziero \& Soller 569 (UPCB, CAS).

30.22. Meniscium maxonianum (A. R. Sm.) R.S. Fern. \& Salino, Phytotaxa 184(1): 9: 2014.

Assemelha-se à Meniscium longifolium Desv., entretanto, em $M$. longifolium os tricomas da face abaxial da pina são setiformes e em M. maxonianum, estes são glandulares (Salino \& Semir, 2004b). Espécie terrícola, crescendo nas trilhas ou às margens de estradas, em locais úmidos.

Material selecionado examinado: Mazziero \& Soller 675 (UPCB, SP, CAS); Mazziero \& Soller 831 (UPCB, NY, CAS); Mazziero \& Soller 862 (UPCB, SP, UNIP, CAS).

30.23. Meniscium serratum Cav., Descr. PI. 548. 1802.

Separa-se das espécies brasileiras, por apresentar margem das pinas serreada a uncinado-serreada (Salino \& Semir, 2004b). Espécie terrícola, observada em local brejoso nas bordas da floresta, crescendo a pleno sol.

Material selecionado examinado: Mazziero \& Soller 863 (UPCB); Mazziero 1003 (UPCB); Mazziero 1005 (UPCB, SP, UNIP).

30.24. Steiropteris decussata (L.) A. R. Sm., Phytokeys 57: 45. 2015. 
Assemelha-se à Steiropteris hatschbachii (A. R. Sm.) Salino \& T. E. Almeida, mas esta possui caule reptante, indúsio e não apresenta aeróforos e tricomas glandulares (vs. caule ereto, indúsio ausente, aeróforos e tricomas glandulares presentes, em $T$. decussata) (Salino \& Semir, 2002). Espécie terrícola, encontrada em trilhas ou no interior da floresta, em locais sombreados e úmidos.

Material selecionado examinado: Mazziero 1010 (UPCB, SP, CAS).

30.25. Steiropteris hatschbachii (A. R. Sm.) Salino \& T. E. Almeida, Phytokeys 57: 46. 2015.

Dentre as espécies ocorrentes no Estado de São Paulo a mais semelhante à $S$. hatschbachii é S. decussata (Salino \& Semir, 2002), sendo a diferença entre elas indicada nos comentários sobre a segunda (item 30.24). Espécie terrícola, ocorre às margens de riachos, no interior da floresta (Salino \& Semir, 2002).

Material selecionado examinado: BRASIL. São Paulo, Mun. Iporanga, Sítio Pica-pau - Bairro Betari, 28.XII.1992, J.M. Torezan 152 (UEC).

\section{Conclusões}

O expressivo número de espécies de samambaias e licófitas encontradas no PETAR, provavelmente, está relacionado com o seu bom estado de preservação e a alta diversidade de ambientes. Além disso, os resultados encontrados no presente estudo, evidenciam a importância do Parque na conservação e preservação das samambaias e licófitas.

O presente estudo possibilita a identificação de um número elevado de espécies, além de apresentar comentários para a distinção de taxa próximos, sendo uma importante ferramenta para a identificação das samambaias e licófitas do sudeste do Estado de São Paulo.

\section{Agradecimentos}

Agradecemos aos seguintes taxonomistas pelo auxilio na determinação de algumas espécies: Dra. Claudine M. Mynssen (Diplazium), Dr. Fernando B. Matos (Elaphoglossum), Dra. Luciana Melo (Elaphoglossum) e Pedro B. Schwartsburd (Hypolepis). A CAPES pela bolsa de mestrado concedida ao primeiro autor. Aos revisores anônimos pelas valiosas sugestões.

\section{REFERÊNCIAS}

Aidar, M. P. M., J. R. Godoy, J. Bergman \& C. A. Joly. 2001. Atlantic Forest succesion over calcarious soil, Parque Estadual Turístico do Alto Ribeira - PETAR, SP. Braz. J. Bot. 24: 455-469.
Almeida, T. E. 2017. Microgramma in Lista de Espécies da Flora do Brasil. Jardim Botânico do Rio de Janeiro. Disponível em: <http:// floradobrasil.jbrj.gov.br/jabot/floradobrasil/ FB91654>. Acesso em: 19 Dez. 2017.

Alston, A. H. G. 1958. The Brazilian species of Elaphoglossum. Bol. Soc. Brot. 38: 1-32.

Alston, A. H. G., A. C. Jermy \& J. M. Rankin. 1981. The genus Selaginella in tropical South America. Bull. Br. Mus. Nat. Hist. Bot. 9: 233330.

Alvares, C. A., J. L. Stape, P. C. Sentelhas, J. L. Moraes \& G. Sparovek. 2014. Köppens climate classification map for Brazil. Meterol. Z. 22: 711-728.

Assis, E. L. M. \& P. H. Labiak. 2009. Polypodiaceae da borda oeste do Pantanal sul-matogrossense, Brasil. Braz. J. Bot. 32: 233-247.

Assis, F. C. \& A. Salino. 2017. Pecluma. In: Flora do Brasil 2020 em construção. Jardim Botânico do Rio de Janeiro. Disponível em: <http://floradobrasil.jbrj.gov.br/jabot/floradobrasil/FB91696>. Acesso em: 12 Dez. 2017.

Boer, J. G. W. 1962. The new world species of Trichomanes sect. Didymoglossum and Microgonium. Acta Bot. Neerl. 11: 277-330.

Boldrin, A. H. L. \& J. Prado. 2007. Pteridófitas terrestres e rupícolas do forte das Andradas, Guarujá, São Paulo, Brasil. Bol. Bot. Univ. São Paulo. 25: 1-69.

Brade, A. C. 1961. O gênero Elaphoglossum no Brasil. I. Chave para determinar as espécies do gênero. Rodriguésia. 35-36: 20-47.

Cislinsk, J. 1996. O gênero Diplazium Sw. (Dryopteridaceae, Pteridophyta) no Estado do Paraná, Brasil. Acta Bot. Bras. 10: 59-77.

Condack, J. P. S. 2015. Dicksoniaceae. In: Lista de Espécies da Flora do Brasil. Jardim Botânico do Rio de Janeiro. Disponível em: <http:// floradobrasil.jbrj.gov.br/jabot/floradobrasil/ FB90945>. Acesso em: 03 Abr. 2017.

Christensen, C. 1913. A monography of the genus Dryopteris, Part I: The tropical American pinnatifid-bipinnatifid species. Kongelige Danske Videnskabers-Selskabs Skrifiter Naturdidenskabeliger og Mathematisk Afdeling. 10: 55-282.

Christenhusz, M. J. M. 2010a. Danaea (Marattiaceae) revisited: biodiversity, a new classification and ten new species of a Neotropical fern genus. Bot. J. Linn. Soc. 163: 360-385.

Christenhusz, M. J. M. 2010b. Revision of the Neotropical genus Eupodium (Marattiaceae). Kew Bull. 65: 115-121. 
Dittrich, V. A. O. 2005. Estudos taxonômicos no gênero Blechnum L. (Pteridophyta: Blechnaceae) para as regiões sudeste e sul do Brasil. Tese de Doutorado. UNESP. Rio Claro. 208 p.

Dittrich, V. A. O \& A. Salino. 2015. Blechnaceae. In: Lista de Espécies da Flora do Brasil. Jardim Botânico do Rio de Janeiro. Disponível em: <http://floradobrasil.jbrj.gov.br/jabot/ floradobrasil/FB90784>. Acesso em: $01 \mathrm{Abr}$. 2017.

Dittrich, V. A. O., A. Salino \& R. Monteiro. 2015. The Blechnum occidentale (Blechnaceae, Polypodiopsida) species group in southern and southeastern Brazil. Phytotaxa. 231: 201-229.

Dittrich, V. A. O., A. Salino, R. Monteiro \& A. L. Gasper. 2017. The family Blechnaceae (Polypodiopsida) in Brazil: Key to the genera and taxonomic treatment of Austroblechnum, Cranfillia, Lomaridium, Neoblechnum and Telmatoblechnum for southern and southeastern Brazil. Phytotaxa. 303: 001-033.

Evans, A. M. 1969. Interspecific relationship in the Polypodium pectinatum-plumula complex. Ann. Missouri Bot. Gard. 55: 193-253.

Fernandes, I. 1997. Taxonomia e fitogeografia de Cyatheaceae e Dicksoniaceae nas regiões Sul e Sudeste do Brasil. Tese de Doutorado. USP. São Paulo. 435 p.

Fidalgo. O. \& V. L. R. Bononi. 1984. Técnicas de coleta, preservação e herborização de material botânico. Instituto de Botânica de São Paulo, São Paulo.

Garcia, P. A \& A. Salino. 2008. Dryopteridaceae (Polypodiopsida) no estado de Minas Gerais, Brasil. Lundiana. 9: 3-27.

Giudice, G. E., M. L. Luna, C. Carrion \& E. R. Sota. 2008. Revision of the genus Salpichlaena J. Sm. (Blechnaceae, Pteridophyta). Am. Fern J. 98: 49-60.

Gissi, D. S. 2017. Psilotaceae. In: Flora do Brasil 2020 em construção. Jardim Botânico do Rio de Janeiro. Disponível em: <http://floradobrasil.jbrj.gov.br/jabot/floradobrasil/ FB91791>. Acesso em: 20 Fev. 2018.

Gonzales, R. J. \& M. Kessler. 2011. A synopsis of the Neotropical species of Sticherus (Gleicheniaceae), with a description of nine new species. Phytotaxa. 31: 1-54.

Guthjar, M. R. 1993. Critérios relacionados com a compartimentação climática de bacias hidrográficas: a bacia do Rio Ribeira do Iguape. Dissertação de Mestrado. USP. São Paulo. 90 p.
Hirai, R. Y. 2015. Selaginellaceae. In: Lista de Espécies da Flora do Brasil. Jardim Botânico do Rio de Janeiro. Disponível em: <http:// floradobrasil.jbrj.gov.br/jabot/floradobrasil/ FB92068>. Acesso em: $21 \mathrm{Fev} .2018$.

Hirai, R. Y. \& J. Prado. 2000. Selaginellaceae Willk. no Estado de São Paulo, Brasil. Braz. J. Bot. 23: 313-339.

Hirai, R. Y. \& J. Prado. 2011. Criptógamos do Parque Estadual das Fontes do Ipiranga, São Paulo, SP. Pteridophyta: 10. Hymenophyllaceae. Hoehnea. 38: 501-510.

Hovenkamp, P. H. \& F. Miyamoto. 2005. A conspectus of native and naturalized species of Nephrolepis (Nephrolepidaceae) in the World. Blumea. 50: 279-322.

IPNI. 2017. The International Plant Names Index. Disponível em: <http://www.ipni.org>. Acesso em: 09 dez. 2017.

Ivanauskas, N. M., R. L. Miashike, J. R. L. Godoy, F. M. Souza, M. M. Kanashiro, I. F. A. Mattos, M. T. Z. Toniato \& G. A. D. C. Franco. 2012. A vegetação do Parque Estadual Turístico do Alto Ribeira (PETAR), São Paulo, Brasil. Biot. Neotrop. 12: 147-177.

Karmann, I \& J. A. Ferrari. 2002. Craste e cavernas do Parque Estadual Turístico do Alto Ribeira (PETAR), SP - Sistemas de cavernas com paisagens subterrâneas únicas, p. 401413. In: C. Schobbenhaus, D.A. Campos, E.T. Quiroz, M. Winge \& M.L.C. Berbet-Bom (Eds.). Sítios geológicos e paleontológicos do Brasil. Comissão Brasileira de Sítios Geológicos e Paleobiológicos (SIGEP), Brasília.

Kessler, M. \& Smith, A. R. 2017. Prodromus of a fern flora for Bolivia. XVI. Salviniaceae. Phytotaxa. 329: 97-100.

Kramer, K. U. 1957. A revision of the genus Lindsaea in the New World with notes on allied genera. Acta Bot. Nerrl. 6: 97-290.

Labiak, P. H. 2015. Marattiaceae. In: Lista de Espécies da Flora do Brasil. Jardim Botânico do Rio de Janeiro. Disponível em: <http:// floradobrasil.jbrj.gov.br/jabot/floradobrasil/ FB91483>. Acesso em: 03 Abr. 2017.

Labiak, P. H. \& R. Y. Hirai. 2015. Moranopteris. In: Lista de Espécies da Flora do Brasil. Jardim Botânico do Rio de Janeiro. Disponível em: <http://floradobrasil.jbrj.gov.br/jabot/ floradobrasil/FB91674>. Acesso em: 03 Abr. 2017.

Labiak, P. H. \& J. Prado. 1998. Pteridófitas epífitas da Reserva Volta Velha, Itapoá - Santa Catarina, Brasil. Bol. Inst. Bot. 11: 1-79. 
Labiak, P. H. \& J. Prado. 2003. Grammitidaceae (Pteridophyta) no Brasil com ênfase nos gêneros Ceradenia, Cochlidium e Grammitis. Hoehnea. 30: 243-283.

Labiak, P. H. \& J. Prado. 2005a. As espécies de Terpisichore A. R. Sm. e Zygophlebia L.E. Bishop (Grammitidaceae) no Brasil. Acta Bot. Bras. 19: 867-887.

Labiak, P. H. \& J. Prado. 2005b. As espécies de Lellingeria A. R. Sm. \& R. C. Moran (Grammitidaceae - Pteridophyta) do Brasil. Braz. J. Bot. 28: 1-22.

Labiak P. H. \& J. Prado. 2005c. As espécies de Melpomene e Micropolypodium (Grammitidaceae - Pteridophyta) no Brasil. Bol. Bot. Univ. São Paulo. 23: 51-69.

Labiak, P. H. \& J. Prado. 2008. New combinations in Serpocaulon and provisional key for the Atalntic Rain Forest species. Am. Fern J. 98: 139-159.

Labiak, P. H., G. Rouhan \& M. Sundue. 2010. Phylogeny and taxonomy of Leucotrichum (Polypodiaceae), a new genus of grammitid ferns from neotropics. Taxon. 59: 911-921.

Labiak, P. H., F. B. Matos, G. Rouhan, J. G. Hanks \& R. C. Moran. 2017. Notes on the taxonomy and growth habits of three species of Campyloneurum (Polypodiaceae) of southeastern Brazil. Am. Fern J. 107: 1-20.

Lavalle, M. C. 2003. Taxonomía de las espécies neotropicales de Marattia (Marattiaceae). Darwiniana. 41: 61-86.

Lellinger, D. B. 1972. A revision of the fern genus Niphidium. Am. Fern J. 62: 101-121.

Léon, B. 1992. Taxonomic revision of the fern genus Campyloneurum (Polypodiaceae). Tese de Doutorado. Universidade de Arhus. Dinamarca. $105 \mathrm{p}$.

Matos, F. B. \& J. T. Mickel. 2014. The Brazilian species of Elaphoglossum sect. Polytrichia (Dryopteridaceae). Brittonia. 66: 371-395.

Matos, F. B., A. R. Smith \& P. H. Labiak. 2010. A new species of Thelypteris (Thelypteridaceae) from southeastern Bahia, Brazil. Brittonia. 62: 149-152.

Mazziero, F. F. F. \& F. R. Nonato. 2015. Ferns and lycphytes from Jaú, SP, Brazil. Checklist. 11: 1798 .

Mazziero, F. F. F., P. H. Labiak \& M. L. B. Paciencia. 2015. Checklist of ferns and lycophytes from the Parque Estadual Turístico do Alto Ribeira, Iporanga, São Paulo, Brazil. Checklist. 11: 1791 .

Mickel, J. T. \& A. R. Smith. 2004. The Pteridophytes of Mexico. Memoirs of the New York Botanical Garden, New York.
Mickel, J. T. 2016. Anemia. Flora Neotropica Monographs. The New York Botanical Garden, New York, USA.

Moran, R. C. 1987. Monograph of the Neotropical genus Polybotrya (Dryopteridaceae). Bull. Ill. Nat. Hist. Surv. 34: 1-187.

Moran, R. C. 1991. Monograph of the Neotropical genus Stigmatopteris (Dryopteridaceae). Ann. Missouri Bot. Gard. 78: 857-914.

Moran, R. C. 1995a. Blechnaceae, p. 326. In: R. C. Moran \& R. Riba (Eds.). Psilotaceae a Salvinaceae. In: G. Davidse, M. Sousa \& S. Knapp (Eds.). Flora Mesoamericana. Universidad Autânoma de México, Ciudad de México.

Moran, R. C. 1995b. Tectariaceae, p. 204-209. In: R. C. Moran \& R. Riba (Eds.). Psilotaceae a Salvinaceae. In: G. Davidse, M. Sousa \& S. Knapp (Eds.). Flora Mesoamericana. Universidad Autânoma de México, Ciudad de México.

Moran, R. C. 2000. Monograph of the Neotropical species of Lomariopsis (Lomariopsidaceae). Brittonia. 52: 55-111.

Moran, R. C. 2008. Diversity, biogeography and floristics, p. 367-394. In: T.A. Ranker \& C.H. Haufler (Eds.). Biology and evolution of ferns and lycophytes. Cambridge University Press, Cambridge.

Moran, R. C. \& P. H. Labiak. 2016. The 1-pinate species of Campyloneurum (Polypodiaceae). Brittonia. 68: 1-11.

Moran, R. C., P. H. Labiak \& M. Sundue. 2010. Synopsis of Mickelia, a newly recognized genus of bolbitidoid ferns (Dryopteridaceae). Brittonia. 62: 337-356.

Moran, R. C., J. Prado \& P. H. Labiak. 2009. Megalastrum (Dryopteridaceae) in Brazil, Paraguay, and Uruguay. Am. Fern J. 99: 1-44.

Morton, C. V. 1947. The American species of Hymenophyllum section Sphaerocionium. Contrib. Unit. St. Nat. Herb. 29: 139-201.

Murakami, N. \& R. C. Moran. 1993. Monograph of the Neotropical species of Asplenium sect. Hymenasplenium (Aspleniaceae). Ann. Missouri Bot. Gard. 80: 1-38.

Mynssen, C. M. 2011. Woodsiaceae (Hook.) Herter (Polypodiopsida) no Estado do Rio Grande do Sul, Brasil. Pesquisas: Botânica. 62: 273-298.

Mynssen, C. M. 2015. Athyriaceae. In: Lista de Espécies da Flora do Brasil. Jardim Botânico do Rio de Janeiro. Disponível em: <http:// floradobrasil.jbrj.gov.br/jabot/floradobrasil/ FB108637>. Acesso em: 02 Abr. 2017.

Navarrete, H. \& B. Øllgaard. 2000. The fern genus Dennstaedtia (Dennstaedtiaceae) in Ecuador - new characters, new species and new combinations. Nord. J. Bot. 20: 319-346. 
Nessel, H. 1955. Lycopodiaceae. Flora Brasílica. 2: 1-131.

Nóbrega, G. A. \& J. Prado. 2008. Pteridófitas da vegetação nativa do Jardim Botânico Municipal de Bauru, Estado de São Paulo, Brasil. Hoehnea. 35: 7-55.

Nóbrega, G.A. \& J. Prado. 2017. Equisetaceae. In: Flora do Brasil 2020 em construção. Jardim Botânico do Rio de Janeiro. Disponível em: <http://floradobrasil.jbrj.gov.br/jabot/ floradobrasil/FB91157>. Acesso em: 06 Abr. 2017.

Nóbrega, G. A., M. P. M. Aidar, M. L. B. Paciencia \& J. Prado. 2016. Identification key for lycophytes and ferns from the Picinguaba and Santa Virgínia nuclei, Parque Estadual da Serra do Mar, Ubatuba, SP, Brazil. Biot. Neotrop. 16: 1-15.

Nonato, F. R. \& P. G. Windisch. 2004. Vittariaceae (Pteridophyta) do sudeste do Brasil. Braz. J. Bot. 27: 149-161.

Øllgaard, B. 1992. Neotropical Lycopodiaceae - an overview. Ann. Missouri Bot. Gard. 79: 687-717.

Øllgaard, B. \& P. G. Windisch. 1987. Sinopse das Lycopodiáceas do Brasil. Bradea. 5: 1-43.

Øllgaard, B. \& P. G. Windisch. 2014. Lycopodiaceae in Brazil. Conspectus of the family I: the genera Lycopodium, Austrolycopodium, Diphasium and Diphasiastrum. Rodriguésia. 65: 293-309.

Øllgaard, B. \& P. G. Windisch. 2016. Lycopodiaceae in Brazil. Conspectus of the family II: the genera Lycopodiella, Palhinhaea and Pseudolycopodiella. Rodriguésia. 67: 691719.

Pacheco, L. 1995. Hymenophylaceae, p. 150163. In: R. C. Moran \& R. Riba (Eds.). Psilotaceae a Salvinaceae. In: G. Davidse, M. Sousa \& S. Knapp (Eds.). Flora Mesoamericana. Universidad Autânoma de México, Ciudad de México.

Palacios-Rios, M. 1987. Psilotaceae, p. 1-6. In: Á. Gomez-Pompa \& L. Gama (Eds.). Flora de Veracruz. Instituto Nacional de Investigaciones sobre Recursos Bióticos, Xalapa.

Pichi-Sermolli, R. E. G. \& M. P. Bizzarri. 2005. A revision of Raddi's pteridological collection from Brazil. Webbia. 60: 1-393.

Ponce, M. 2007. Sinopsis de las Thelypteridaceae de Brasil central y Paraguay. Hoehnea. 34: 283-333.

PPG I. 2016. A community-derived classification for extant lycophytes and ferns. J. Syst. Evol. 54: 563-603.
Prado, J. 1998. Pteridófitas do Estado de São Paulo, p. 47-61. In: Bicudo, C. M. E. \& G. J. Shepherd (Orgs.). Biodiversidade do Estado de São Paulo. 2. Fungos macroscópicos e plantas. FAPESP, São Paulo.

Prado, J. 2003. New species in Adiantum (Pteridaceae) from Brazil. Am. Fern. J. 93: 76-80.

Prado, J. 2004. Criptógamos do Parque Estadual das Fontes do Ipiranga, São Paulo, SP. Pteridophyta: 14. Ophioglossaceae. Hoehnea. 31: 171-174.

Prado, J. 2015b. Pteridaceae. In: Lista de Espécies da Flora do Brasil. Jardim Botânico do Rio de Janeiro. Disponível em: <http:// floradobrasil.jbrj.gov.br/jabot/floradobrasil/ FB92016>. Acesso em: 01 Abr. 2017.

Prado, J. \& R. Y. Hirai. 2008. Criptógamos do Parque Estadual das Fontes do Ipiranga, São Paulo, SP. Pteridophyta: 13. Lycopodiaceae e 20. Selaginellaceae. Hoehnea. 35: 543-552.

Prado, J. \& R. Y. Hirai. 2010a. Criptógamos do Parque Estadual das Fontes do Ipiranga, São Paulo, SP. Pteridophyta: 21. Tectariaceae. Hoehnea. 37: 367-376.

Prado, J. \& R. Y. Hirai. 2011. Checklist das licófitas e samambaias do Estado de São Paulo. Biota Neotropica. 1: 1-30.

Prado, J., R. Y. Hirai \& P. B. Schwartsburd. 2010. Criptógamos do Parque Estadual das Fontes do Ipiranga, São Paulo, SP. Pteridophyta: 9. Grammitidaceae e 16. Polypodiaceae. Hoehnea. 37: 445-460.

Prado, J. \& P. H. Labiak. 2003. Flora de Grão-Mongol, Minas Gerais: Pteridófitas. Bol. Bot. Univ. São Paulo. 21: 25-47.

Prado, J. \& P. H. Labiak. 2009. Pteridófitas, p. 269-289. In: Lopes, M. I. M. S., M. Kirizawa \& M. M. R. F. Melo (Eds.). Patrimônio da Reserva Biológica do Alto da Serra de Paranapiacaba: a antiga Estação Biológica do Alto da Serra. Instituto de Botânica, São Paulo.

Prado, J. \& D. B. Lellinger. 2002. Adiantum argutum, an unrecognized species of A. latifolium group. Am. Fern J. 92: 23-29.

Prado, J., L. S. Sylvestre, P. H. Labiak, P. G. Windisch, A. Salino, I. C. L. Barros, R. Y. Hirai, T. E. Almeida, A. C. P. Santiago, M. A. Kieling-Rubio, A. F. N. Pereira, B. Øllgaard, C. G. V. Ramos, J. T. Mickel, V. A. O. Dittrich, C. M. Mynssen, P. B. Schwartsburd, J. P. S. Condack, J. B. S. Pereira \& F. B. Matos. 2015. Diversity of ferns and lycophytes in Brazil. Rodriguésia. 66: 1073-1083.

Prado, J. \& P. G. Windisch. 2000. The genus Pteris L. (Pteridaceae) in Brazil. Bol. Inst. Bot. 13: 103-199. 
Ramos, C. G. V. \& L. S. Sylvestre. 2010. Lycopodiaceae no Parque Nacional do Itatiaia, RJ e MG, Brasil. Acta Bot. Bras. 24: 25-46.

Riba, R. 1995. Lophosoriaceae, p. 85. In: R. C. Moran \& R. Riba (Eds.). Psilotaceae a Salvinaceae. In: G. Davidse, M. Sousa \& S. Knapp (Eds.). Flora Mesoamericana. Universidad Autânoma de México, Ciudad de México.

Ribeiro, M. C., J. P. Metzger, A. C. Martensen, F. J. Ponzoni \& M. M. Hirota. 2009. The Brazilian Atlantic Forest: how much is left, and how is the remaining Forest distributed? Implications for conservation. Biol. Cons. 142: 1141-1153.

Rojas-Alvarado, A. F. 2010. Novelties in Saccoloma inaequale complex (Saccolomataceae) from the Neotropics. Métodos en Ecología y Sistemática. 5: 1-16.

Rolim, L. B. \& A. Salino. 2008. Polypodiaceae Bercht \& J. Presl (Polypodiopsida) no Parque Estadual do Itacolomi, MG, Brasil. Lundiana. 9: 83-106.

Salino, A. 1996. Levantamento das pteridófitas da Serra do Cuzcuzeiro, Analândia, SP, Brasil. Braz. J. Bot. 19: 173-178.

Salino, A. 2002. New species and combinations in Thelypteris subg. Goniopteris (Thelypteridaceae). Brittonia. 54: 331-339.

Salino, A. \& T. E. Almeida. 2008. Pteridófitas do Parque Estadual do Jacupiranga, SP, Brasil. Acta Bot. Bras. 22: 983-991.

Salino, A. \& T. E. Almeida. 2015. Salviniaceae. In: Lista de Espécies da Flora do Brasil. Jardim Botânico do Rio de Janeiro. Disponível em: <http://floradobrasil.jbrj.gov.br/jabot/ floradobrasil/FB92028>. Acesso em: $01 \mathrm{Abr}$. 2017.

Salino, A. \& C. A. Joly. 2001. Pteridophytes of three remnants of gallery forests in the Jacaré-Pepira River basin, São Paulo State, Brazil. B. Herb. Ezechias Heringer. 8: 5-15.

Salino, A. \& L. C. N. Melo. 2000. A new species of the fern genus Thelypteris (Thelypteridaceae) from southeastern Brazil. Novon. 10: 74-77.

Salino, A. \& P. O. Morais. 2003. New combinations in the Tropical American Ctenitis (Tectariaceae). Am. Fern J. 93: 32-35.

Salino, A. \& J. Semir. 2002. Thelypteridaceae (Polypodiophyta) do Estado de São Paulo: Macrothelypteris e Thelypteris subgêneros Cyclosorus e Steiropteris. Lundiana. 3: 9-27.

Salino, A. \& J. Semir. 2004a. Thelypteris subg. Amauropelta (Thelypteridaceae - Pteridophyta) no Estado de São Paulo, Brasil. Lundiana. 5: 83-112.
Salino, A. \& J. Semir. 2004b. Thelypteris subg. Meniscium (Thelypteridaceae - Pteridophyta) no Estado de São Paulo, Brasil. Braz. J. Bot. 27: 103-114.

Schwartsburd, P. B. 2015. Dennstaedtiaceae. In: Lista de Espécies da Flora do Brasil. Jardim Botânico do Rio de Janeiro. Disponível em: <http://floradobrasil.jbrj.gov.br/jabot/ floradobrasil/FB90941>. Acesso em: $01 \mathrm{Abr}$. 2017.

Schwartsburd, P. B. \& P. H. Labiak. 2007. Pteridófitas do Parque Estadual de Vila Velha, Paraná, Brasil. Hoehnea. 34: 159-209.

Schwartsburd, P. B. \& P. H. Labiak. 2008. Eriosorus areniticola (Pteridaceae), a new species from Brazil, Am. Fern J. 98: 160-163.

Schwartsburd, P. B. \& J. Prado. 2015. A taxonomic revision of the South America species of Hypolepis (Dennstaedtiaceae), Part I. Am. Fern J. 105: 263-313.

Schwartsburd, P. B. \& A. R. Smith. 2013. Novelties in Serpocaulon (Polypodiaceae). J. Bot. Res. Inst. Tex. 7: 85-93.

Sehnem, A. 1970. Polypodiáceas, p. 1-173. In: R. Reitz (Ed.). Flora ilustrada catarinense. Herbário Barbosa Rodrigues, Itajaí.

Senna, R. M. 2004. Adiantopsis cheilantoides (Pteridaceae - Pteridophyta) uma nova espécie do Rio Grande do Sul, Brasil. Iheringia, Sér. Bot. 59: 107-110.

Silva, F. D., F. P. Athayde Filho \& P. G. Windisch. 2015. Schizaeaceae (Polypodiopsida) no Estado do Mato Grosso, Brasil. Pesquisas: Botânica. 68: 107-118.

Smith, A. R. 1995. Polypodiaceae, p. 219-248. In: Berry, P. E., B. K. Holst \& Yatskievych, K. (Eds.). Pteridophytes, Spermatophytes, Acanthaceae - Araceae. In: Steyrmark, J. A., P. E. Berry \& B. K. Holst (Eds.). Flora of the Venezuelan Guayana. Missouri Botanical Garden, St. Louis.

Sota, E. R. 1960. Polypodiaceae y Grammitidaceae Argentinas. Opera Lilloana. 5: 1-229.

Splink. 2018. Species Link. Disponível em: <http://www.splink.cria.org.br>. Acesso em: 17 jan. 2017.

Stolze, R. G. 1976. Ferns and ferns allies of Guatemala. Part I: Ophioglossaceae through Cyatheaceae. Fieldiana Botany. 39: 1-164.

Stolze, R. G. 1981. Ferns and ferns allies of Guatemala. Part II: Polypodiaceae. Fieldiana Botany New Series. 6: 1-548.

Sundue, M., R. Y. Hirai \& J. Prado. 2013. Ruhmora glandulosissima (Dryopteridaceae) a new species from the Atlantic Rain Forest, and revision of the species occurring in Brazil. Syst. Botany. 38: 915-924. 
Sylvestre, L. S. 2001. Revisão taxonômica das espécies da família Aspleniaceae A. B. Frank ocorrentes no Brasil. Tese de Doutorado. USP. São Paulo. 571 p.

Sylvestre, L. S. 2010. Notas nomenclaturais em Aspleniaceae (Polypodiopsida) ocorrentes no Brasil. Rodriguésia. 61: 109-114.

Sylvestre, L. S. 2015. Aspleniaceae. In: Lista de Espécies da Flora do Brasil. Jardim Botânico do Rio de Janeiro. Disponível em: <http:// floradobrasil.jbrj.gov.br/jabot/floradobrasil/ FB90718>. Acesso em: 24 Fev. 2018.

Tryon, R. M. 1942. A revision of the genus Doryopteris. Contributions of the Gray Herbarium of Harvard University. 43: 1-80.

Tryon, R. M. 1986. The biogeography of species, with special reference to ferns. Bot. Rev. 52: 117-154.

Tryon, R. M. \& R. G. Stolze. 1989a. Pteridophyta of Peru. Part I. 1. Ophioglossaceae 12. Cyatheaceae. Fieldiana Botany New Series. 20: 1-145.

Tryon, R. M. \& R. G. Stolze. 1989b. Pteridophyta of Peru. Part II. 13. Pteridaceae - 15. Dennstaedtiaceae. Fieldiana Botany New Series. 22: 1-128.

Tryon, R. M. \& R. G. Stolze. 1993. Pteridophyta of Peru. Part V. 18. Aspleniaceae - 21. Polypodiaceae. Fieldiana Botany New Series. 32: 1-190.

Tryon, R. M. \& R. G. Stolze. 1994. Pteridophyta of Peru. Part VI. 22. Marsileacae - 28. Isoetaceae. Fieldiana Botany New Series. 34: 1-140.

Tryon, R. M. \& A. F. Tryon. 1982. Ferns and allied plants, with special refrence to Tropical America. Springer-Verlag, New York.

Vasco, A., R. C. Moran \& G. Rouhan. 2009. Monograph of the Elaphoglossum ciliatum group (Dryopteridaceae). Brittonia. 61: 241272.

Vasques, D. T. \& J. Prado. 2011. Campyloneurum C. Presl (Polypodiaceae) no Estado de São Paulo, Brasil. Hoehnea. 38: 147-163.

Viveros, R. S. \& A. Salino. 2017. Ctenitis. In: Lista de Espécies da Flora do Brasil. Jardim Botânico do Rio de Janeiro. Disponível em: <http://floradobrasil.jbrj.gov.br/jabot/floradobrasil/FB90960>. Acesso em: 01 Abr. 2017.

Weigand, A. \& M. Lehnert. 2016. The scaly tree ferns (Cyateaceae-Polypodiopsida) of Brazil. Acta Bot. Bras. 30: 336-350.

Windisch, P. G. 1992a. Pteridófitas da região norte-ocidental do Estado de São Paulo: guia para estudos e excursões. 2ed., Universidade Estadual Paulista, São José do Rio Preto.
Windisch, P. G. 1992b. Trichomanes crispum L. (Pteridophyta, Hymenophyllaceae) and allied species. Bradea. 6: 78-117.

Windisch, P. G. 2014. Hymenophyllaceae (Polypodiopsida) no estado do Rio Grande do Sul. Pesquisas: Botânica. 65: 15-48.

Windisch, P. G. 2015. Hymenophyllaceae. In: Lista de Espécies da Flora do Brasil. Jardim Botânico do Rio de Janeiro. Disponível em: <http://floradobrasil.jbrj.gov.br/jabot/floradobrasil/FB91174>. Acesso em: 02 Abr. 2017.

Windisch, P. G, Ramos, C. G. V. \& Øllgaard, B. 2015. Lycopodiaceae. In: Lista de Espécies da Flora do Brasil. Jardim Botânico do Rio de Janeiro. Disponível em: <http://floradobrasil. jbrj.gov.br/jabot/floradobrasil/FB128525>. Acesso em: 21 Fev. 2018.

Winter, S. L. S., L. S. Sylvestre \& J. Prado. 2011. O gênero Adiantum (Pteridaceae) no Estado do Rio de Janeiro, Brasil. Rodriguésia 62: 663-681.
Recebido em 01.X.2017

Aceito em 27.II.2018 